\title{
Probabilistic Estimates of the Seismic Ground-Motion Hazard in Western Saudi Arabia
}

\section{U.S. GEOLOGICAL SURVEY BULLETIN 1868}

Prepared in cooperation with the Ministry of Petroleum and Mineral Resources, Deputy Ministry of Mineral Resources, Kingdom of Saudi Arabia

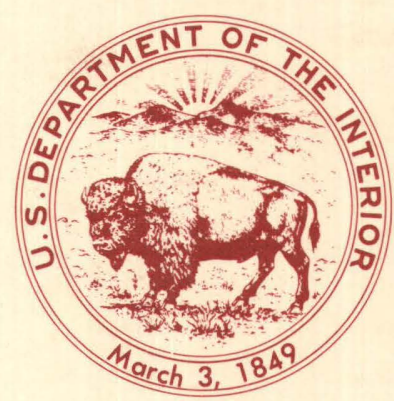


Instructions on ordering publications of the U.S. Geological Survey, along with prices of the last offerings, are given in the current-year issues of the monthly catalog "New Publications of the U.S. Geological Survey." Prices of available U.S. Geological Survey publications released prior to the current year are listed in the most recent annual "Price and Availability List." Publications that are listed in various U.S. Geological Survey catalogs (see back inside cover) but not listed in the most recent annual "Price and Availability List" are no longer available.

Prices of reports released to the open files are given in the listing "U.S. Geological Survey Open-File Reports," updated monthly, which is for sale in microfiche from the U.S. Geological Survey, Books and Open-File Reports Section, Federal Center, Box 25425, Denver, CO 80225. Reports released through the NTIS may be obtained by writing to the National Technical Information Service, U.S. Department of Commerce, Springfield, VA 22161; please include NTIS report number with inquiry.

Order U.S. Geological Survey publications by mail or over the counter from the offices given below.

\section{BY MAIL}

\section{Books}

Professional Papers, Bulletins, Water-Supply Papers, Techniques of Water-Resources Investigations, Circulars, publications of general interest (such as leaflets, pamphlets, booklets), single copies of Earthquakes \& Volcanoes, Preliminary Determination of Epicenters, and some miscellaneous reports, including some of the foregoing series that have gone out of print at the Superintendent of Documents, are obtainable by mail from

\section{U.S. Geological Survey, Books and Open-File Reports Federal Center, Box 25425 Denver, CO 80225}

Subscriptions to periodicals (Earthquakes \& Volcanoes and Preliminary Determination of Epicenters) can be obtained ONLY from the

\section{Superintendent of Documents \\ Government Printing Office \\ Washington, D.C. 20402}

(Check or money order must be payable to Superintendent of Documents.)

Maps

For maps, address mail orders to

\section{U.S. Geological Survey, Map Distribution \\ Federal Center, Box 25286 \\ Denver, CO 80225}

Residents of Alaska may order maps from

\author{
Alaska Distribution Section, U.S. Geological Survey, \\ New Federal Building - Box 12 \\ 101 Twelfth Ave., Fairbanks, AK 99701
}

\section{OVER THE COUNTER}

\section{Books}

Books of the U.S. Geological Survey are available over the counter at the following Geological Survey Public Inquiries Offices, all of which are authorized agents of the Superintendent of Documents:

- WASHINGTON, D.C.--Main Interior Bldg., 2600 corridor, 18 th and C Sts., NW.

- DENVER, Colorado--Federal Bldg., Rm. 169, 1961 Stout St.

- LOS ANGELES, California--Federal Eldg., Rm. 7638, 300 N. Los Angeles St.

- MENLO PARK, California--Bldg. 3 (Stop 533), Rm. 3128, 345 Middlefield Rd.

- RESTON, Virginia--503 National Center, Rm. 1C402, 12201 Sunrise Valley Dr.

- SALT LAKE CITY, Utah--Federal Bldg., Rm. 8105, 125 South State St.

- SAN FRANCISCO, California--Customhouse, Rm. 504, 555 Battery St.

- SPOKANE, Washington--U.S. Courthouse, Rm. 678, West 920 Riverside Ave..

- ANCHORAGE, Alaska--Rm. 101, 4230 University Dr.

- ANCHORAGE, Alaska--Federal Bldg, Rm. E-146, 701 C St.

\section{Maps}

Maps may be purchased over the counter at the U.S. Geological Survey offices where books are sold (all addresses in above list) and at the following Geological Survey offices:

- ROLLA, Missouri--1400 Independence Rd.

- DENVER, Colorado--Map Distribution, Bldg. 810, Federal Center

- FAIRBANKS, Alaska--New Federal Bldg., 101 Twelfth Ave. 


\title{
Probabilistic Estimates of the Seismic Ground-Motion Hazard in Western Saudi Arabia
}

\author{
By PAUL C. THENHAUS, S.T. ALGERMISSEN, \\ DAVID M. PERKINS, STANLEY L. HANSON, \\ and WILLIAM H. DIMENT
}

Prepared in cooperation with the Ministry of Petroleum and Mineral Resources, Deputy Ministry of Mineral Resources, Kingdom of Saudi Arabia 


\title{
DEPARTMENT OF THE INTERIOR DONALD PAUL HODEL, Secretary
}

\author{
U.S. GEOLOGICAL SURVEY
}

Dallas L. Peck, Director

Any use of trade, product, industry, or firm names in this publication is for descriptive purposes only and does not imply endorsement by the U.S. Government.

For sale by the Books and Open-File Reports Section U.S. Geological Survey Federal Center Box 25425

Denver, CO 80225

\section{Library of Congress Cataloging-in-Publication Data}

Probabilistic estimates of the seismic ground-motion hazard in western Saudi Arabia.

(U.S. Geological Survey bulletin ; 1868)

Supt. of Docs. no.: I 19.3:1868

1. Seismology-Saudi Arabia. 2. Geodynamics. I. Thenhaus, Paul C. II. Series.

QE75.B9 no. 1868

$557.3 \mathrm{~s} \quad\left[551.2^{\prime} 2^{\prime} 09538\right]$

88-600434 [QE537.2.S33] 


\title{
CONTENTS
}

\author{
Abstract 1 \\ Introduction 1 \\ Overview of probabilistic model 2 \\ Hazard model 2 \\ Seismic-source-zone model 2 \\ Earthquake-occurrence model $\mathbf{3}$ \\ Ground-motion-attenuation model 3 \\ Probability distribution of ground motion 4 \\ Tectonic settings of seismic source zones 5 \\ Dead Sea rift 5 \\ Gulf of Aqaba (Elat) 5 \\ Dead Sea Basin 7 \\ Lebanon Mountains segment 8 \\ Fault-source model for Dead Sea rift 8 \\ Gulf of Suez 8 \\ Red Sea rift 10 \\ Fault-source model for Red Sea rift 13 \\ Gulf of Aden 13 \\ Fault-source model for Gulf of Aden 15 \\ Afar depression 15 \\ Western Arabian Peninsula 16 \\ Earthquake-recurrence model 18 \\ Seismicity parameters $\quad 18$ \\ Seismic-rate allocation sequence and methods \\ Maximum magnitudes 20 \\ Modeling earthquake events 21 \\ Ground-motion attenuation 21 \\ Preferred attenuation model 26 \\ Ground-motion hazard maps 26 \\ Discussion and recommendations 29 \\ Acknowledgments $\quad 36$ \\ References cited 36

Appendix-Seismic activity rates of source zones and source faults

\section{FIGURES}

1. Diagram and graphs showing elements of the probabilistic hazard model 2

2-5. Maps showing:

2. Tectonic, geologic, and geographical features and sites

3. Seismic source zones 7

4. Fault-source model 9

5. Seismicity of the region 12

6. Block diagrams showing process of rigid-plate rifting $\mathbf{1 4}$

7. Chart showing allocation scheme of seismic activity rate $\mathbf{1 9}$ 
8. Cross section showing interpreted velocity structure along the southwestern Saudi Arabian geophysical transect $\mathbf{2 2}$

9. Index map showing the location of three ground-motion profiles

10-15. Graphs showing:

10. Profiles of peak horizontal acceleration applying various assumptions to two attenuation models 25

11. Profiles of peak horizontal velocity applying various assumptions to two attenuation models 25

12. Acceleration attenuation curves illustrating high and low extremes of attenuation relations $\quad \mathbf{2 7}$

13. Velocity attenuation curves illustrating high and low extremes of attenuation relations $\mathbf{2 8}$

14. Acceleration attenuation curves for the preferred hazard model 29

15. Velocity attenuation curves for the preferred hazard model

16-19. Maps showing:

16. Peak horizontal acceleration with a 90 percent probability of not being exceeded in $100 \mathrm{yr}$, given by the preferred hazard model 31

17. Peak horizontal velocity with a 90 percent probability of not being exceeded in $100 \mathrm{yr}$, given by the preferred hazard model $\mathbf{3 2}$

18. Peak horizontal acceleration with a 90 percent probability of not being exceeded in $100 \mathrm{yr}$, given by the upper-bound hazard model 33

19. Peak horizontal velocity with a 90 percent probability of not being exceeded in $100 \mathrm{yr}$, given by the upper-bound hazard model $\mathbf{3 4}$

20. Graph showing profiles of peak horizontal acceleration with and without attenuation variability $\mathbf{3 5}$

21. Graph showing profiles of peak horizontal velocity with and without attenuation variability 35

\section{TABLES}

1. Estimates of $b$-values using two maximum-likelihood techniques $\mathbf{1 8}$

2. Comparison of peak ground-motion values at Haql, Yanbu, Jiddah, and Jizan obtained from the preferred and upper-bound regional hazard models 


\title{
Probabilistic Estimates of the Seismic Ground-Motion Hazard in Western Saudi Arabia
}

\author{
By Paul C. Thenhaus, S.T. Algermissen, David M. Perkins, \\ Stanley L. Hanson, and William H. Diment
}

\section{Abstract}

Estimates of seismic horizontal ground acceleration and velocity having a 90 percent probability of nonexceedance in 100 years in western Saudi Arabia indicate the highest relative levels of ground motion are expected in regions neighboring the Gulf of Aqaba and North Yemen. Estimated ground motions within the shield area are relatively low, whereas the central and northern coastal plain regions are characterized by intermediate-level groundmotion values that are generally governed by far-field effects of earthquakes in the central Red Sea rift.

The seismic hazard estimates are derived from regional seismic source zones that are based on interpretations and assumptions relating potential seismic activity to the Precambrian through Tertiary structural framework of the region. Because statistical variability in ground-motion attenuation relations is known to be a dominant source of uncertainty in estimated probabilistic ground-motion values, and because strong-motion records do not exist for the Arabia peninsula, hazard maps have been developed using both a preferred low- $Q$ attenuation function and a conservative high- $Q$ attenuation function. Values resulting from the high-Q attenuation function are considered upper-bound estimates to the hazard model.

Progress toward a more complete understanding of the seismic hazards of western Saudi Arabia is expected from broad-scope, interdisciplinary geological, seismological, and related geophysical investigations aimed at improving our understanding of all parameters that have gone into the probabilistic ground-motion estimates. Identification of areas in which geological hazards such as landsliding and liquefaction may occur for ground shaking levels suggested in this report will do much to quantify these hazards in a preliminary manner.

\section{INTRODUCTION}

The use of probabilistic ground-motion maps to represent seismic hazard has evolved from experience with a number of other types of map representations during the 30-yr history of regional seismic hazard mapping in the United States. Historical seismicity maps are factual and can serve to warn that earthquakes occur more widely than people usually recognize. Epicenter maps, however, only provide information about the geographical location of earthquakes and, in some cases, information about the depth of earthquakes. Epicenter maps provide no direct information concerning: (1) expected levels of ground motion, and (2) the generalization of historical seismicity to likely areas of future seismicity. Historic maximum intensity maps provide information on levels of damaging ground motion, but they do not provide information on the relative frequency of occurrence of specific levels of ground motion in various geographical areas. Intensity maps may, therefore, overstate the hazard in areas where a large earthquake occurred historically but where the frequency of such occurrences is low. Probabilistic seismic ground-motion maps properly focus on hazardous ground motions, allow the use of interdisciplinary geological, seismological, and geophysical information to assist in the generalization of the historic record to likely areas of future earthquakes, and properly represent the hazard with respect to the expected frequency of earthquake and ground-motion occurrence. Such maps of the contiguous United States (Algermissen and Perkins, 1976; Algermissen and others, 1982) have found widespread use in building code applications, regional land-use planning, emergency preparedness, and insurance analyses. In addition, such 


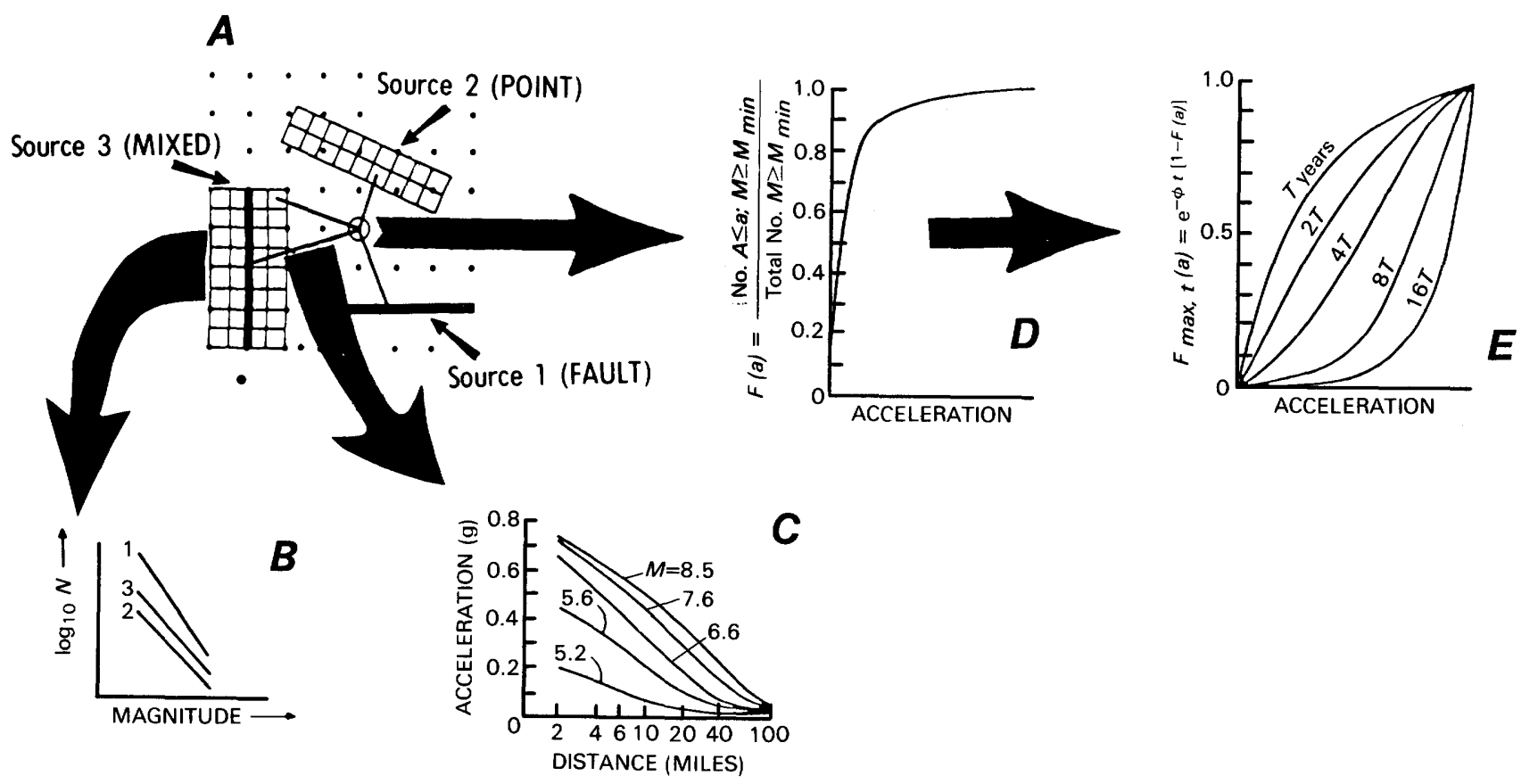

Figure 1. Elements of the probabilistic hazard model. $A$, Types of seismic source zones and grid of points at which the hazard is to be computed. B, Statistical analysis of seismicity data. $C$, Ground-motion attenuation curves for various magnitude levels. $D$, Cumulative conditional probability distribution of acceleration at a site on the grid of points. $E$, The extreme probability $F_{\text {max, }}(a)$ for various accelerations and exposure times $(T)$. Bold arrows key graphs to their respective elements in the source zones and on the computation grid.

maps can serve to prioritize regions for further research and point out those studies most useful in furthering the understanding of the seismic hazard problem.

\section{OVERVIEW OF PROBABILISTIC MODEL}

\section{Hazard Model}

In this study, earthquakes are exponentially distributed with regard to magnitude and randomly distributed with regard to time. The exponential magnitude distribution is an assumption based on empirical observation. The distribution of earthquakes in time is assumed to be Poissonian. The assumption of a Poisson process for earthquakes in time is consistent with historical earthquake occurrence insofar as it affects the regional probabilistic hazard calculation. On a regional basis, large shocks closely approximate a Poisson process, whereas small shocks may depart significantly from a Poisson process. The ground motions associated with small earthquakes are of only marginal interest in engineering applications, and consequently the Poisson assumption serves as a useful and simple model (Cornell, 1968).
The production of a probabilistic ground-motion hazard map involves the development of four constituent models. These are: (1) a seismic-source-zone model that defines the spatial distribution of earthquakes within the region of concern (fig. $1 A$ ), (2) an earthquakeoccurrence model that describes the recurrence of events in time within the seismic source zones (fig. 1B), (3) a ground-motion-attenuation model that describes mathematically the manner in which earthquake ground motions decrease with distance from an earthquake source for various magnitude levels (fig. $1 C$ ), and (4) a probability model for calculating the expected maximum amplitude of ground motion within a given period of time corresponding to a chosen probability level for a number of individual sites in the region (fig. 1D).

\section{Seismic-Source-Zone Model}

Three idealized seismic source areas are shown in figure $1 A$. Earthquakes within each source zone can be modeled as: (1) point sources in areas (used to represent earthquakes for which the fault rupture lengths are small compared with the map scale being used); (2) finite rupture lengths along two-dimensional (linear) fault sources; or (3) a mixed source, for example, point sources for small earthquakes and fault (two dimensional) sources for larger earthquakes. 
All earthquakes are assumed to be shallow shocks consis tent with the worldwide observations of earthquake depths in regions of crustal rifting and consistent with the earthquake data base used in the development of the attenuation models applied in this study.

\section{Earthquake-Occurrence Model}

For each seismic source, the magnitude distribution was taken to be exponential and of the form given by the Richter relation of occurrence frequencies (fig. $1 B$ ):

$$
\log N=a+\mathrm{b} M
$$

where $N$ is the number of earthquakes in a given magnitude range centered about magnitude $M$ and $a$ and $b$ are constants to be determined. Because seismicity in our region of concern is generally low, and research has shown that significant errors in the computed b-value occur when the total number of earthquakes are less than about 40 (Bender, 1982), $b$-values for regional collections of source zones having total numbers of earthquakes from 60 to 150 were computed. The $b$ values were computed using maximum-likelihood techniques described by Bender (1983) and Weichert (1980).

The small number of earthquakes in many of the seismic source zones also precludes direct assessment of $a$-values for individual zones. Hence, a regional rate of earthquake activity was calculated by summing all the activity in all the seismic source zones. This regional rate of activity was then apportioned among the individual source zones so that the amount of activity applied to any one zone is in rough proportion to the number of earthquake events occurring in that zone. The procedure, therefore, attempts to maintain the relative seismic flux among source zones consistent with the historic record of events.

The future spatial occurrence of earthquakes is assumed to be uniform throughout each source zone. That is, if each seismic source area is divided into $n$ small divisions (such as shown in fig. $1 A$ ) and if the number of earthquakes likely to occur in any magnitude range is $N$, then the number of earthquakes likely to occur in this magnitude range in each small division or block of a source area is

$$
\frac{N}{n}
$$

If seismicity is distributed along a fault of length $L$, the distribution of earthquakes is somewhat more complicated. We have used the relationship between fault rupture length $(L)$ and magnitude $(M)$ suggested by Mark (1977):

$$
\log (L)=1.915+0.389 M
$$

where $L$ is the average surface rupture length in meters and $M$ is as already defined. If there are $N_{M_{g}}-M_{1}$ earthquakes in the magnitude interval $M_{2}-M_{1}$ that have an average length of rupture (determined from equation 3 ) of $L_{\text {ave }}$ and we are modeling a fault of length $X$, the earthquakes are distributed at the rate of

$$
\frac{N_{M_{2}}-M_{1}}{X-L_{\text {ave }}}
$$

earthquakes per unit of length along the fault. If one end of a fault is located at $X_{1}$ and the other end at $X_{2}$, the earthquake rupture centers are assumed to occur uniformly between $X_{1}+\frac{L_{\text {ave }}}{2}$ and $X_{2}-\frac{L_{\text {ave }}}{2}$ along the fault.

Bender (1984b) provides details regarding the finitefault-rupture model used in this study.

\section{Ground-Motion-Attenuation Model}

The ground-motion-attenuation function is a critical component of the probabilistic ground-motion mapping procedure (fig. $1 C$ ). Research has shown that much of the variability in estimates of peak groundmotion values is due to uncertainties inherent in groundmotion-attenuation models (Bender, 1984a; McGuire and Shedlock, 1981). Although there are a number of published attenuation models available for various tectonic settings and applications (see for example, Campbell, 1985), choice of a single, correct model for western Saudi Arabia is hindered by lack of strong-motion recordings and lack of reliable isoseismal maps due to a relatively low rate of earthquake activity and a sparse population distribution. Hence, there is no direct sampling of the propagation path of earthquake waves within this region. This lack of data leaves a fundamental question as to whether the region is characterized by high, low, or moderate attenuation. Our approach is to investigate the ground-motion hazard implications of both a conservative low-attenuation model (high Q) and a preferred high-attenuation model (low $Q$ ), thereby providing upper-bound and preferred ground-motion estimates within the constraints of seismic source zones and seismic activity rates of this study. 


\section{Probability Distribution of Ground Motion}

Once the seismic activity rate per unit area or per unit length of fault is determined for the seismic source zones of the region, and a ground-motion-attenuation function is decided upon, a distribution of ground motion is calculated (fig. $1 D$ ) for a number of individual sites located on an appropriate grid pattern (fig. 1A) throughout the region.

From the distribution of ground motion at each site (fig. $1 D$ ), it is possible to determine directly the expected number of times a particular amplitude of ground motion is likely to occur in a given period of years at a given site, and thereby, the maximum amplitude of ground motion in a given number of years corresponding to any level of probability (fig. $1 E$ ). The relationship between return period, $R_{y}(a)$, exposure time, $T$, and probability of exceedance during that exposure time, $1-F_{\text {max, }}(a)$, is explained by the following development.

First, the distribution of the expected number of occurrences of ground motion at each location is calculated. The peak ground motion, for example, the peak acceleration corresponding to some extreme probability, is then calculated from the distribution of the expected number of occurrences in the following manner. Let the peak acceleration be $a$, then

$$
F(a)=P\left[A \leq a \mid M>M_{\min }\right]
$$

is the probability that an observed acceleration $A$ is less than or equal to the value $a$, given that an earthquake with magnitude $M$, greater than some minimum magnitude of interest, has occurred. The calculation at a given grid point or along a fault is performed for every acceleration $a$ of interest using:

$F(a)=\frac{\text { expected number of occurrences with } A \leq a \text { and } M>M_{\min }}{\text { total expected number of occurrences }\left(M>M_{\min }\right)}$

A typical $F(a)$ is shown in figure $1 D$.

$F(a)$ is the probability that the acceleration value $a$ will not be exceeded, given that an earthquake larger than the minimum magnitude occurs in the source zone. Therefore $(1.0-F(a))$ is the probability that $a$ will be exceeded. If $\phi$ is the yearly rate at which earthquakes larger than the minimum magnitude occur in the zone, then the expression

$$
\phi(1.0-F(a))
$$

gives the annual rate at which earthquake accelerations greater than $a$ occur. In $T$ years,

$$
T \phi(1.0-F(a))
$$

gives the expected number of occurrences of accelerations greater than $a$ for a period of $T$ years. If earthquake occurrences are rare, and the annual rate of occurrence is the same from year to year (that is, for Poisson occurrences), then probability theory tells us that

$$
\exp (-(\text { expected number }))
$$

is the probability that no such occurrence happens. Thus, the probability that acceleration value $a$ is not exceeded in $T$ years due to an earthquake in the source zone considered is given by the expression

$$
\exp (-T \phi(1.0-F(a)))
$$

which can be rewritten as,

$$
F_{\max , t}(a)=e^{-t[1-F(a)]}
$$

where $T$ now equals a particular exposure time, $t$. Using equation 9, a table of $(a)$ and $F(a)$ is constructed. For a particular exposure time $T=t, F_{\text {max, }}(a)$ is calculated, and the value of $a$ for a given extreme probability, say $F_{\max , t}(a)=0.90$, is found by interpolation.

It is convenient here to define the term return period in years as:

$$
R_{y}(a)=\frac{1}{1-F(a)}
$$

where $R(a)$ is the average number of events that must occur to get an acceleration exceeding $a$. The return period in years is given approximately by

$R_{r}(a)=\frac{R(a)}{\text { expected number of events per year }\left(M \geq M_{\text {min }}\right)}$.

We obtain from equations 10 and 11:

$$
\phi t(1-F(a))=\frac{t}{R_{y}(a)}
$$

thus, from equations 9 and 12:

$$
F_{\max , t}(a)=e^{-t / R y(a)}
$$


and

$$
\ln \left(F_{\max , t}(a)\right)=-\frac{t}{R_{y}(a)} .
$$

For an extreme probability of $F_{\max , t}(a)=0.90$ and an exposure time of $t=100 \mathrm{yr}$ :

$$
\ln (0.90)=-\frac{100}{R_{y}(a)}
$$

or

$$
R_{y}(a)=\frac{100}{0.1054}=949 \mathrm{yr} .
$$

Thus, the average return period for the ground motions we have mapped is about $950 \mathrm{yr}$.

It may be useful to point out that using equation 13 and setting the exposure time equal to the average return period $R_{y}(a)$, that is

$$
t=R_{y}(a)
$$

we have

$$
F_{\text {max, }}(a)=e^{-1}=0.37
$$

Thus the acceleration with a return period of $R_{y}(a)=t$ years has a probability of

$$
1-F_{\max , t}(a)=1-0.37=0.63 \text { or } 63 \text { percent }
$$

of being exceeded in $t$ years. The point is that accelerations (or any other parameter) with a particular return period have a 63 percent probability of being exceeded during an exposure time equal to that return period.

Frequently, it is convenient to express the maximum ground motion in terms of the annual probability of exceedance. Let $r_{T}(a)$ be the probability of exceedance of ground motion $a$ in $T$ years; then

$$
F_{\max , T}(a)=1 \multimap r_{T}(a)=e^{-T / R_{y}(a)}
$$

and

$$
r_{T}(a)=1-e^{-T / R_{y}(a)}
$$

for $T=1 \mathrm{yr}$, equation 17 becomes

$$
r_{T}(a)=1-e^{-\frac{1}{R_{r}(a)}}
$$

when $R_{y}(a)$ is sufficiently large (say, greater than $10 \mathrm{yr}$ ),

$$
r_{T}(a)=\frac{1}{R_{y}(a)}
$$

\section{TECTONIC SETTINGS OF SEISMIC SOURCE ZONES}

\section{Dead Sea Rift}

The Dead Sea rift is a 1,000-km-long sinistral-slip boundary between the Arabian and Sinai plates (fig. 2). Although commonly referred to as a rift, the structures defining the plate boundary result from transform movement along a shear zone that connects the Red Sea spreading ridge with the Zagros collisional zone of Turkey. Inception of shear movement coincided with initial rifting of the Red Sea in pre-Miocene time, and offset Precambrian through Cretaceous rock units indicate about $105 \mathrm{~km}$ of cumulative left-slip movement. The average slip rate is estimated to be $0.7-1.0 \mathrm{~cm} / \mathrm{yr}$ over the last 4-5 m.y. Late Quaternary fault displacements have been mapped along the length of the transform boundary (Garfunkel, 1981); however, structural style and trend and contemporary seismic activity vary considerably. We have, therefore, segmented the transform plate boundary into three separate source zones to reflect these differences (fig. 3). A growing body of knowledge indicates that discrete segments of large strike-slip faults possess varying seismological characteristics generally governed by large-scale crustal asperities and varying strike of the fault trace within a uniform, regional stress regime (Sykes and Seeber, 1982; Sieh, 1981; Nishenko and McCann, 1981; Sykes and Nishenko, 1984). The three source zone segments, from south to north, are (1) the Gulf of Aqaba-Arva Valley, (2) the Dead Sea rift, and (3) the Lebanon Mountains segments. Finer distinctions than used in this study could perhaps be made in the Dead Sea rift and the Jordan fault segments because of subaerial exposure of most of the fault system and a larger number of earthquakes recorded in this region. However, because this study concerns western Saudi Arabia, finer distinctions in seismic sources in the central and northern fault segments would have little influence on ground motions that affect northwestern Saudi Arabia.

\section{Gulf of Aqaba (Elat)}

The Gulf of Aqaba (fig. 2) is the widest and deepest segment of the transform plate boundary and is characterized by the structural development of enechelon rhomb-grabens (pull-apart basins). Three such grabens, each filled by a few kilometers of sediment, have 


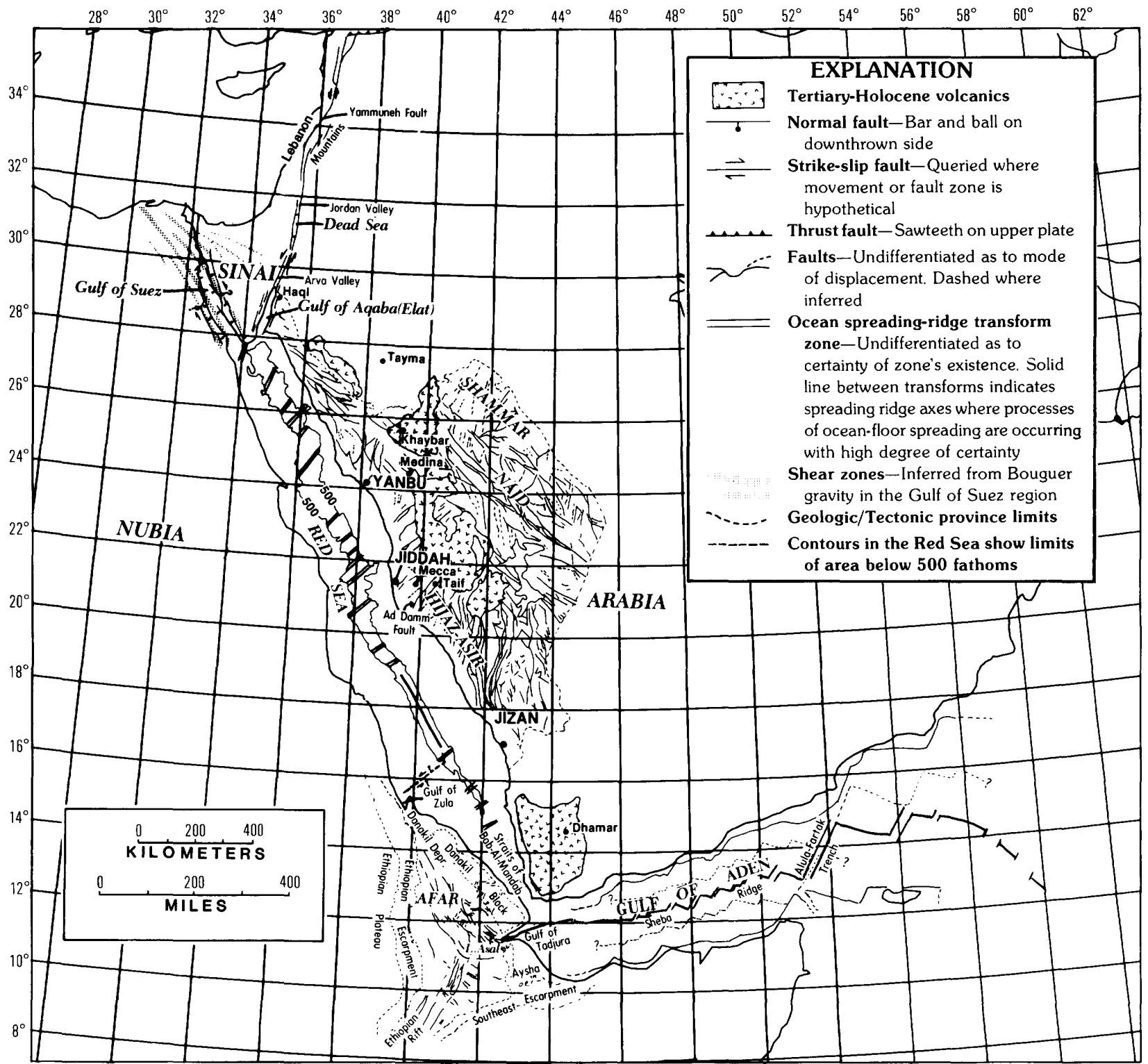

Figure 2. Index map of selected tectonic, geologic, and geographical features and sites referenced in the text. Sources of map compilation by region: (1) Western Arabia peninsula: Ministry of Defence, United Kingdom (1980), Brown (1972), Greenwood and others (1980), Coleman (1973), Merghelani and others (1981); (2) Dead Sea rift: Garfunkel (1981), Eyal and others (1981), Garfunkel and others (1981); (3) Gulf of Suez: Garfunkel and Bartov (1977), Riad (1977); (4) Red Sea: Drake and Girdler (1964), Hall (1980), Coleman (1973); (5) Gulf of Aden: Laughton (1966), Laughton and others (1970), Cochran (1981, 1982); and (6) Afar: Kronberg and others (1975), Barberi and others (1975).

been inferred to underlie the Gulf of Aqaba (Garfunkel, 1981). Rhomb-graben development is a common structural style along transform plate boundaries where the strike of the transform deviates from the regional slip direction; such grabens have been long recognized in the United States as important structural elements along the transform plate boundary of southern California (Crowell, 1974). Local extension across the transform zone results in small-magnitude crustal separation and a "leaky" transform boundary. Garfunkel (1981) estimated
$35-40 \mathrm{~km}$ of young slip is adequate to open the rhombgrabens of the Gulf of Aqaba. Separation of the Precambrian crust across the transform boundary is estimated to be about $1 \mathrm{~km}$ in the central and southern segments. Older, Miocene and post-Miocene slip was distributed throughout a broader region of shear neighboring the gulf. Sinistrally offset Miocene dikes intruded in the Precambrian crystalline rocks of eastern Sinai suggest $24 \mathrm{~km}$ of cumulative post-Miocene offset on a shear system of anastomosing strike-slip faults in a 30-km-wide 


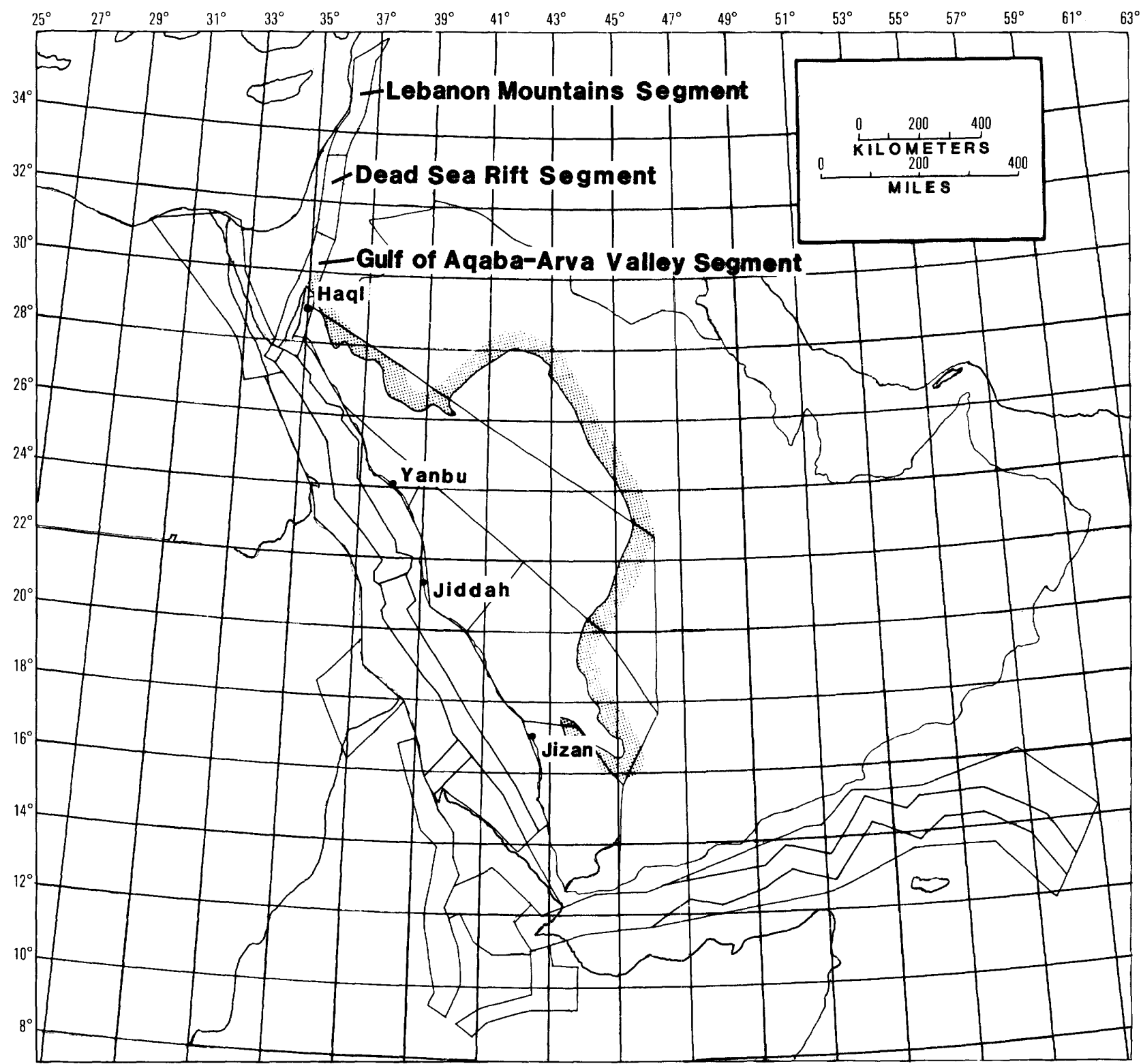

Figure 3. Seismic source zones of the Arabian shield, Red Sea rift, and contiguous tectonic systems used in this study. Stippled area highlights outcrop boundary of Precambrian crystalline rocks in western Saudi Arabia.

zone neighboring the gulf (Eyal and others, 1981). Similar displacement is estimated for the eastern coast of the Gulf of Aqaba (Eyal and others, 1981). Thus, some $60 \mathrm{~km}$ of the total $110-\mathrm{km}$ offset along the transform system is taken up by faults within the gulf itself. North of the Gulf of Aqaba, faults of the Dead Sea transform boundary are subaerially exposed in the Arva Valley. Active en-echelon left-slip faults are evident within this topographic saddle, whereas normal-slip faults delimit some of the margins (Garfunkel, 1981). In the northern Arva Valley, the Arva Valley fault bounds the eastern margin of the topographic depression and has a distinct topographic expression; late Quaternary movement along this fault occurred over a length exceeding $100 \mathrm{~km}$ (Garfunkel and others, 1981; Garfunkel, 1981).

\section{Dead Sea Basin}

The trend of the transform boundary shifts from a predominantly north-northeast trend through the Gulf of Aqaba-Arva Valley area to a predominantly north-south trend along the Dead Sea basin (fig. 2). Topographically, the Dead Sea occupies the lowest portion of the subaer- 
iarially exposed transform boundary. The Arva fault bounds the east side of the Dead Sea basin, but structural expression of the fault diminishes to the north. The Jordan (Jericho) fault, a major sinistral fault en echelon to the Arva, bounds the Dead Sea basin to the west. The Dead Sea occupies a rhomb-graben between the two sinistral slip faults. Trenching studies across the Jordan (Jericho) fault indicate two large earthquakes in the past $2,000 \mathrm{yr}$; one event occurred between 200 B.C. and A.D. 200 and the other between A.D. 700 and A.D. 900 (Reches and Hoexter, 1981). Other, smaller events could be inferred. Precise dating of the events is precluded because of poor soil development and the predominance of coarse clastic deposits in the region. Left-lateral distortion and dislocation of walls of an 8th-century palace located somewhat west of the main trace of the Jordan fault (Reches and Hoexter, 1981) indicate that not all the shear strain is accommodated along the main trace of the Jordan fault, but some is distributed throughout a broader area of the Jordan Valley. Average slip rate on the Dead Sea portion of the transform is estimated to be $0.7 \mathrm{~cm} / \mathrm{yr}$ (Reches and Hoexter, 1981), which is consistent with the average slip of the overall plate boundary of $0.7-1.0 \mathrm{~cm} / \mathrm{yr}$. The Jordan fault continues northward through the Jordan Valley to the Sea of Galilee. Mountain fronts on either side of the Jordan Valley are fault controlled, and locally at their bases, scarps attain several tens of meters in height (Garfunkel and others, 1981). In the valley near the Jordan fault trace, lacustrine beds are tilted at $30^{\circ}$ and, locally, are gently folded within a few hundred meters from the fault, which indicates a small amount of compression across the fault (Garfunkel and others, 1981).

\section{Lebanon Mountains Segment}

North of the Jordan Valley, the transform boundary splays into three large fault strands (fig. 2). The central strand, the Yammuneh fault, follows a sinuous course northward through the Lebanon Mountains. The sharp easterly bend in the transform boundary through this segment results in a strong constraining bend in the left-slip transform system. The resultant transpression is postulated as causing large topographic uplifts on either side of the fault (Quennell, 1956). The other two large splay faults may also be active, but their surface traces die out some 50-60 km north of the Jordan Valley (Garfunkel and others, 1981).

Ben-Menahem (1981) noted a nonuniform distribution of seismic slip along the length of the Dead Sea transform zone. Although moderate-to-large earthquakes have occurred in all of the above three segments of the transform zone, historic and contemporary microseismic activity is considerably lower in the Gulf of Aqaba-Arva Valley segment than in the central and northern segments. Lack of historically reported large earthquakes $(M>7)$ in the southern segment could be due to the historically sparse population of this region; however, low levels of microseismic activity recorded during recent monitoring tends to support the general distribution of the macroseismic data (Ben-Menahem and Aboodi, 1971). BenMenahem (1981) concluded that a large portion of the total slip is accommodated aseismically in the south, whereas to the north, as the Zagros collisional zone is approached, slip becomes purely seismic. This thesis is consistent with the tectonic style of the transform boundary in its northern segments. North of the Dead Sea, compression across the transform boundary increases considerably because of the large constraining bend through the Lebanon Mountains that results, perhaps, in predominantly stick-slip fault movement. The tectonic setting is generally similar to the "big bend" region of the San Andreas fault in southern California that broke in 1857 in a great earthquake and that has a prehistoric record of characteristically breaking in large events (Sieh, 1978). Sykes and Seeber (1982) referred to these large bends in transform boundaries as tectonic knots and concluded that they are areas of considerable stress accumulation because of their difficulty in accommodating relative plate motion.

\section{Fault-Source Model for Dead Sea Rift}

The three segments of the Dead Sea rift are modeled as mixed-source types of seismic source zones (fig. 1A); that is, linear fault-rupture sources are modeled within a broader area source (fig. 4). Earthquakes with $M_{s} \geq 6.5$ are modeled as twodimensional sources, whereas earthquakes with $M_{s} \leq 6.5$ are modeled as point sources throughout the area source. Two fault sources are modeled $20 \mathrm{~km}$ apart and central to the area source. Double, parallel faults were modeled in each of the three segments to better represent the en-echelon nature of long Quaternary strike-slip faults (that generally bound rhomb-grabens) and to account for deformation extending beyond a single fault trace.

\section{Gulf of Suez}

As in the case of the Dead Sea transform (fig. 2), additional detail in seismic source zones could perhaps be provided for eastern Egypt. However, because additional detail in source zones of this region would have little affect on resultant ground motions in extreme northern Saudi Arabia, we have not attempted detailed zones in this region. 


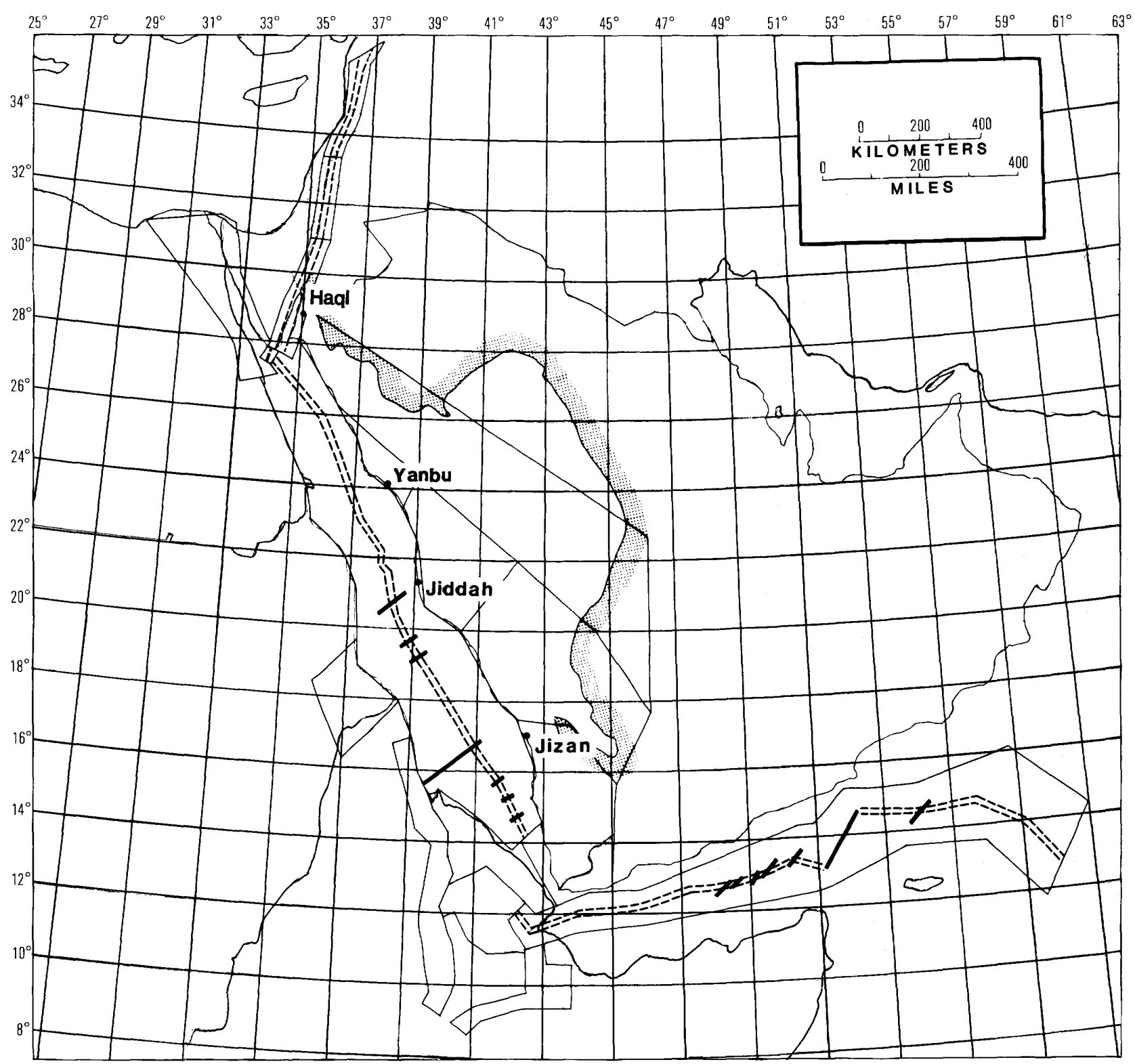

Figure 4. Fault-source model for the Dead Sea-Red Sea-Gulf of Aden rift system used in this study. Stippled area highlights outcrop boundary of Precambrian crystalline rocks in western Saudi Arabia.

Although age of incipient rifting along the Suez arm of the Red Sea rift is not precisely known, stratigraphic evidence indicates rifting was well underway by late Oligocene to early Miocene time (30-20 m.y. ago.) (Garfunkel and Bartov, 1977). An estimated 15-20 km of crustal stretching in the southern part of the rift was accommodated through faulting and block tilting. However, crustal separation was too small to result in production of oceanic lithosphere between the Sinai and Nubian plates (Garfunkel and Bartov, 1977). Amounts of crustal stretching decrease northward along the rift.

Although the primary episode of deformation along the Suez arm of the rift was completed by late
Miocene time, slow subsidence of the gulf has continued through the Quaternary. Quaternary fault scarps are generally concentrated along a central trough and along the eastern border fault (Garfunkel and Bartov, 1977); they retain a zig-zag pattern inherited from middle Tertiary structural fabric. Young uplift of the rift margins is indicated by fragmentary evidence of uplifted marine terraces and reefs (Garfunkel and Bartov, 1977) on the flanks of the southern part of the rift.

North of the gulf, structures of the rift are covered by eolian dunes and deltaic deposits of the Nile River. However, a continuous physiographic depression persists northward along a projection of the central trough; it 
forms the physiographic furrow in which the Suez Canal was excavated. Some of the topographically low areas of this depression are below sea level, and Garfunkel and Bartov (1977) argued that stratigraphic evidence, together with the geomorphic evidence, indicates recent subsidence of the canal depression with continental and pluvial sedimentation generally having kept pace with subsidence.

The structural framework of Egypt is complex with four primary, intersecting fault trends being recognized throughout this region. These are (1) the east African fault systems that trend north-south, (2) the Erythrean or African fault system that trends northwesterly, (3) Tethyan faults that trend east-west, and (4) the Aualitic faults that trend northeast-southwest (Said, 1962; Riad, 1977). Riad interpreted a number of northwest-trending, parallel to subparallel shears in northern Egypt based on a Bouger gravity anomaly map of the region (fig. 2). He inferred right-lateral movement across the shear zones based on space-photography and suggestions of independent stratigraphic studies. The northwest strike of the shear zones and dextral sense of movement would be conjugate to the sinistral, northeasttrending Dead Sea transform. Opening of the Gulf of Suez is suggested (Riad, 1977) to have resulted from dextral slip along the shear zones.

The Gulf of Suez seismic source zone is drawn to include those shear zones inferred to be associated with the gulf (fig. 3). The eastern boundary of the zone has been extended northward to include the topographic depression of the Suez Canal. The zone collects a number of historically reported earthquakes in northern Egypt that have been assigned Modified Mercalli intensities (MMI) as high as X (Poirier and Taher, 1980). It is assumed that seismic potential is uniform throughout the zone although this, in fact, is not entirely clear. Structural deformation is most intense in the Gulf of Suez in the southern part of the source zone; however, historically reported events are concentrated in the northern half of the zone. This may be a result of longer settlement of the Nile delta region as compared to the desert regions neighboring the Gulf of Suez.

\section{Red Sea Rift}

Drake and Girdler (1964) recognized three physiographic provinces of the Red Sea (fig. 2). These are the coastal shelves, a broad main trough, and a deep axial trough. The three provinces are present to varying degrees along the length of the Red Sea. North of lat $24^{\circ}$ $\mathrm{N}$., an axial trough is not clearly developed and the shelf areas are quite narrow. Between lat $19^{\circ} \mathrm{N}$. and $24^{\circ} \mathrm{N}$., an axial trough is characterized by a discontinuous series of "deeps" in excess of 1,000 fathoms, and a main trough is well developed. South of lat $19^{\circ} \mathrm{N}$., shelf areas are broad and the axial trough has a continuous, narrow expression to about lat $15^{\circ} \mathrm{N}$. where the main trough shoals into the Straits of Bäb-al-Mandab.

Structural deformation is intense in the axial zone and characterized by numerous normal faults (Ross and Schlee, 1973, 1977; Phillips and Ross, 1970). Marginal to the axial trough, deformation of the main trough is less intense but also characterized by abundant normal faults and folds. Many shallow folds are related to salt flowage and diapirism (Ross and Schlee, 1973, 1977). The transition from axial trough to main trough (roughly following the 500 -fathom bathymetric contour) is marked in places by narrow, intensely faulted zones or large downfaulted blocks (Ross and Schlee, 1973, 1977). Shelf areas are generally characterized by normal faults (more prevalent in the southern Red Sea) and folds related to salt flowage and diapiric intrusion.

The Red Sea was recognized early in the development of global plate tectonic theory as part of the worldwide rift system (Sykes, 1967). However, important aspects concerning the rift's fundamental crustal structure and tectonic development remain uncertain and are topics of much debate in recent geological literature. Central to the debate is the nature of the crust beneath the broad shelf areas of the southern Red Sea. One school of thought holds that the shelf areas in the southern Red Sea are underlain by Miocene age oceanic crust or, at least, mantle-derived crust. A second school of thought argues that the shelf areas are characterized by rifted and extended continental crust. Although it is generally accepted that ocean-floor spreading (creation of new oceanic crust) has been occurring in the axial trough of the southern Red Sea (south of about lat $19.5^{\circ}$ N.) since Pliocene time, a variety of geological, geophysi$\mathrm{cal}$, and plate kinematic arguments have been proposed both suggesting and denying the possibility of early Miocene ocean-floor spreading.

Magnetic signatures obtained across the shelves are subdued due to a late Miocene evaporite sequence, which is about $3 \mathrm{~km}$ thick, that precludes direct observation of deeper basement structure through standard seismic-reflection techniques. Broad, linear magnetic anomalies on the shelves show an abrupt transition to high-frequency anomalies in the coastal plain of southwestern Saudi Arabia. The abrupt transition in signature has commonly been interpreted as the contact between oceanic and continental crust (Gettings, 1977; Hall, 1980; Hall and others, 1977; Girdler and Styles, 1974). Furthermore, these investigators suggested that the low-amplitude broad wavelength anomalies of the shelves are roughly symmetric about the axial trough and generally correlate with Miocene age anomalies of the Heirtzler and others (1968) magnetic time scale. Alternatively, Cochran (1983), following Fraziers' (1970) 
structural interpretation of an area off northern Afar, suggested that the offshore total-intensity magnetic anomalies are due to salt diapirs along large basement faults and, hence, cannot be correlated with oceanfloor-spreading anomalies. Cochran (1983) further noted a correlation of total-intensity magnetic anomalies with free-air gravity anomalies. Cochran stated that this correlation would not be expected if the magnetic anomalies were spreading anomalies, but that this correlation would be allowable if the magnetic signatures derive from faulted basement and salt structures.

Recent plate kinematic reconstructions (Le Pichon and Francheteau, 1978; Cochran 1981, 1983), while applying different fundamental constraints on the amount of rotation of the Arabian and Nubian plates about the Euler pole of McKenzie and others (1970) and using different interpretations of the total number of rigid plates in the region, require an amount of total plate separation in the southern Red Sea more than twice the width of Pliocene-present ocean floor in the axial trough. The required extra space could be accommodated through pre-Pliocene ocean-floor spreading, extended and thinned continental crust, or any combination of unknown percentages of thinned continental crust and mafic intrusion. Abundant geologic evidence exists of significant amounts of mafic intrusion into the continental crust bordering the Red Sea (Schmidt and others, 1983; Blank, 1977). An unresolved issue, however, is the lateral extent of extended continental crust. In models that incorporate Miocene age oceanfloor spreading, this zone is relatively narrow and crops out immediately east of the coastal plain (Schmidt and others, 1983). Alternatively, in Cochran's (1983) interpretation, extended continental crust extends far seaward, beneath the shelves and main trough of the southern Red Sea. Furthermore, the floors of the central and northern Red Sea are suggested to be extended continental crust as Cochran (1983) argued that organized ocean-floor spreading has not yet commenced north of about lat $21^{\circ} \mathrm{N}$. The region between lat $21^{\circ} \mathrm{N}$. and $25^{\circ} \mathrm{N}$. is suggested (Cochran, 1983) to be currently in transition from diffuse continental extension to an ocean-floor spreading mode of plate separation.

Bohannon (1986) has suggested a tectonic model of early Red Sea rift development that incorporates lower to middle crustal expansion through large-scale mafic intrusion with concomitant brittle extension in the upper crust. The magnitude of brittle extension is suggested to be about 40 percent, which is a relatively small value in comparison to estimates of over 100 percent extension along some passive continental margins (Le Pichon and Sibuet, 1981). Incorporating geologic interpretations from field mapping with an interpretation of a seismicrefraction profile (Mooney and others, 1985) that extends across the southern Arabian shield to the
Farasan Islands, Bohannon (1986) envisioned brittle extension accommodated by widely spaced up-to-basin listric normal faults above an east-dipping low-angle detachment that crops out near the eastern coastal plain and roots beneath the Arabian Escarpment. The brittlely extended crust is exposed in a 75-km-wide belt east of the coastal plain and exhibits characteristic arcuate traces of normal faults. Although Bohannon (1986) suggested it is possible that extended continental crust exists beneath the coastal plain, he argued that west of the coastline the crust is of oceanic character.

The regional distribution of seismicity throughout the Red Sea has changed little since the early investigations of Gutenberg and Richter (1954), Drake and Girdler (1964), and Sykes and Landisman (1964). Notably, with an additional $20 \mathrm{yr}$ of data and establishment of the Worldwide Standard Seismograph Network (WWSSN), seismicity remains concentrated proximal to the southern Red Sea rift (fig. 5). Relocation efforts have refined post-1955 earthquake locations to an accuracy of 10-20 km (Sykes and Landisman, 1964; Fairhead and Girdler, 1970) for moderate and large shocks in the region. Reasonable associations with at least region-scale structure can, therefore, be inferred. A large aftershock $\left(m_{b}=5.3\right)$ of the North Yemen earthquake of December 13,1982, was recorded by the WWSSN and a network of portable seismographs deployed in the epicentral region (Langer and Merghelani, 1983). The epicenters determined independently by local and teleseismic data are no more than $5 \mathrm{~km}$ apart, which suggests that contemporary seismic activity in this area can be reliably determined from WWSSN data.

Although seismic activity is concentrated in the southern half of the Red Sea and predominantly confined to the axial trough, the seismicity is not uniformly distributed throughout this area. Some earthquake activity is clustered on, or near, inferred transform faults of the rift axis (fig. 5). Focal mechanisms for two earthquakes located near the southern Red Sea rift axis indicate nearly pure strike-slip movement on northeasttrending planes and suggest contemporary seismic activity on rift transform faults (Fairhead and Girdler, 1970). Other significant activity appears to occur along other portions of the central rift not having recognized transform faults. This activity may be related to either intrusive activity along the axial trough, normal fault movement associated with the downdropping of blocks into the axial trough, or movement along presently undetected transforms.

Figure 3 shows the seismic source zone configurations of the Red Sea used to group historic seismicity for the determination of earthquake recurrence rates. Three primary zones have been constructed. A relatively narrow zone based on the 500-fathom bathymetric contour includes seismicity 


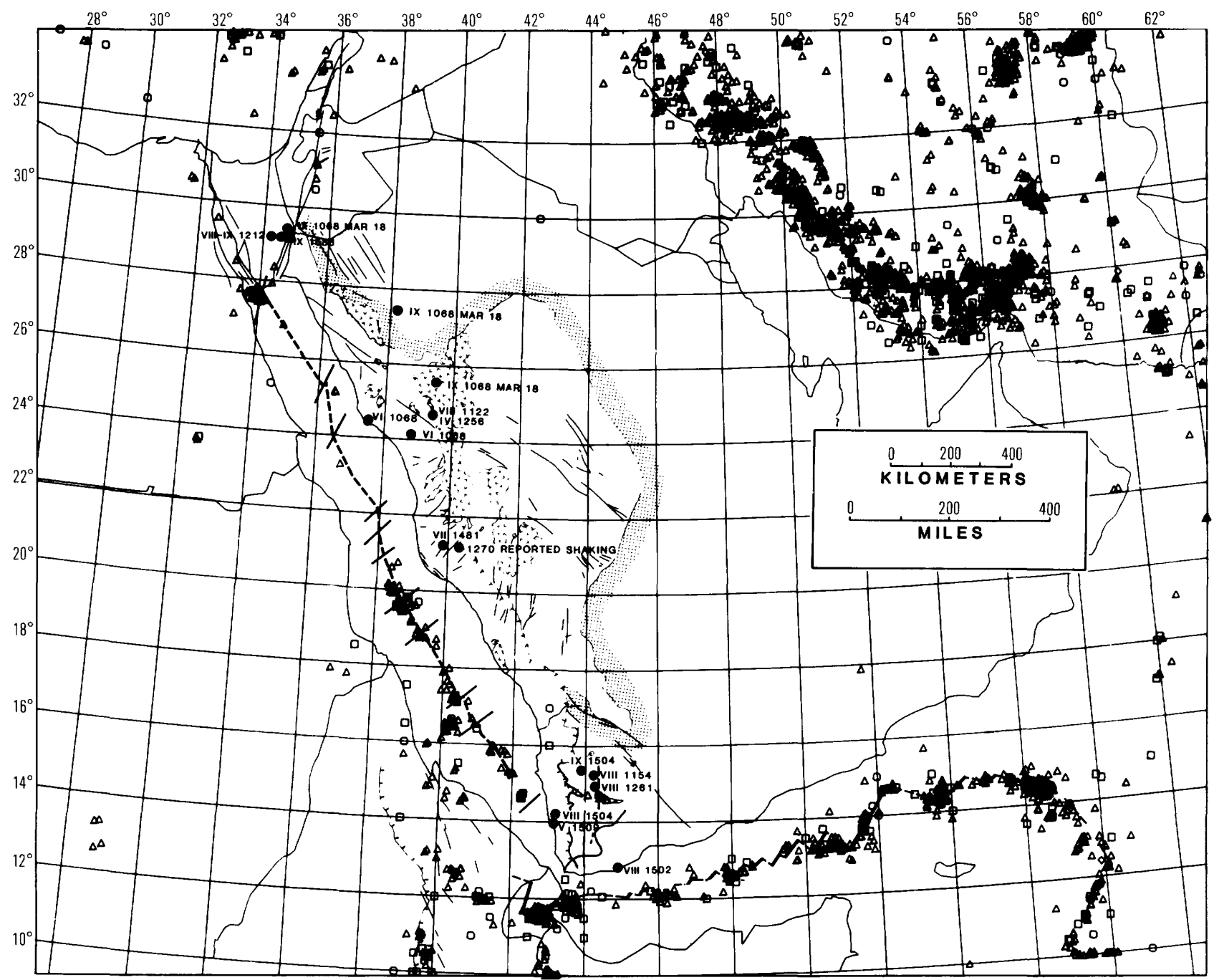

Figure 5. Preliminary map of seismicity of Saudi Arabia and adjacent regions. Computer-generated symbols are earthquakes obtained from the NEIS worldwide seismicity catalog. Modified Mercalli intensities are from Poirier and Taher (1980) and are plotted as solid circles only for the western Arabian peninsula. Locations of intensity values do not necessarily represent epicenter locations; they represent locations of existing reports of shaking effects which may be distant from actual epicenters due to very low population density in western Saudi Arabia. Earthquake symbols represent the following values of magnitude $(M)$ : Triangles $=4 \leq M<5$; squares $=5 \leq M \leq 6$; hexagons $=6 \leq M \leq 7$; diamonds $=7 \leq M<8$; hourglass $=M \geq 8$. Stippled area highlights outcrop boundary of Precambrian crystalline rocks in western Saudi Arabia.

associated with the highly faulted axial trough. This central-rift zone has been subdivided into northern and southern halves based on a significant decrease in observed seismicity north of lat $21^{\circ} \mathrm{N}$. Distinguishing these two segments preserves the influence of the seismically active southern axial trough in the seismic-hazard maps. In the northern half, although an axial trough is not well defined north of lat $24^{\circ} \mathrm{N}$., the few epicenters that are present are contained by the 500 -fathom contour. The broad zone that spans the width of the Red Sea is intended to separate primary, rift-related crust and structure of the main trough and shelves from predominantly Precambrian crust and structure of the Arabian and Nubian shield areas. Because of the previously discussed conflicting interpretations of offshore crustal structure, the eastern boundary of this zone can be interpreted in several different ways. Under hypotheses that advocate a primary plate separation mode of ocean-floor spreading, the zone boundary approximates the full extent of inferred Miocene age oceanic crust. Under the hypothesis of deep-to-middle crustal expansion through extensive diking, the zone boundary separates crust of mantle derivation to the west from continental crustal structure to the east. Under hypotheses of rifted continental crust extending beneath the shelf areas to the margins of the axial trough, the zone boundary separates the region of significant brittle crustal extension from less deformed regions on shore. 
Under this last type of hypothesis the definition of the zone boundary is a matter of degree of deformation, and the boundary becomes arbitrarily located.

\section{Fault-Source Model for Red Sea Rift}

The fault-source earthquake model for the Red Sea rift (fig. 4) is developed from fundamental plate tectonic concepts that serve to explain tectonic processes of active oceanic spreading ridges. The block diagrams of figure 6 schematically illustrate these concepts. First, although the locations of evolving spreading ridges and transforms may be predisposed by ancient structures of the Precambrian continental crust (Sykes, 1978), once ocean-floor spreading is established, structures of the continental and oceanic domains are geologically distinct. Second, once organized ocean-floor spreading is established, seismically active transform faults exist between offset spreading ridges and have earthquakes that exhibit strike-slip focal mechanisms. Wilson (1965) first introduced this concept. Recent microearthquake studies using ocean-bottom seismographs (OBS) have shown this distribution of seismicity to be generally characteristic of oceanic transforms (Francis and others, 1978; Forsyth and Rowlett, 1979; Project Rose Scientists, 1981; Rowlett, 1981). Other information gained from OBS monitoring indicates that seismicity is distributed across the interior plate corners of some ridge-transform intersections. At the regional scale of this investigation, however, this detail is not significant to the fault source model. A third point, not well illustrated by figure 6 , is the characterization of ridge-crest earthquakes by normal focal mechanisms oriented parallel to the ridge strike (Sykes, 1967; Trehu and others, 1981). A generalization used in the fault-source model is that the larger spreading-ridge earthquakes, at any given spreading rate, occur off the spreading-ridge axis by perhaps $10 \mathrm{~km}$ or more (Solomon and Burr, 1979; Burr and Solomon, 1978). Although observed spreading-ridge earthquakes can neither confirm nor deny this generalization, Solomon and Burr (1979) suggested this to be a reasonable assumption based on considerations of observed high heat flow and very thin crust directly within axial troughs.

These concepts and generalizations have been derived from studies of mature ocean-spreading systems worldwide, and it is not entirely clear that they can be applied in a strict sense to the incipient ocean-spreading system of the Red Sea. Conflicting interpretations of the composition and structure of the crust neighboring the axial trough of the southern Red Sea and the unresolved mode of plate separation in the northern Red Sea (brittle extension versus ocean-floor spreading) raise uncertainties in developing a fault-source earthquake model based on worldwide examples of mature ocean-spreading ridges. Because of the youth of the Red Sea rift, an axial rift valley is incompletely developed and offsets of the axial-trough centerline (assumed centerline of rift spreading) across inferred transforms are extremely small, being less than $15 \mathrm{~km}$ (Coleman, 1977) as compared to hundreds of kilometers for some mature spreading systems (Stewart, 1983). The specific geometry of the Red Sea ridge-transform fault system cannot be defined with confidence.

Our approach, therefore, has been to style fault sources in accord with an ocean-spreading-ridge model but to relax some constraints of the rigid-plate transform theory illustrated in figure 6 .

Earthquakes are modeled as linear fault ruptures on parallel, spreading-ridge faults modeled $10 \mathrm{~km}$ either side of the axial-trough centerline as represented by Coleman (1977; fig. 4). Furthermore, in the southern Red Sea axial-trough zone, transform faults as inferred by Hall (1980) have been modeled perpendicular to the spreading-ridge axis; these faults include those identified with reasonable certainty as well as those that are speculative. These transforms, which have been modeled beyond the terminal ends of the offset axial-trough centerline, extend across the entire width of the axial trough as defined by the 500 -fathom bathymetric contour. No transform faults were modeled in the northern axial-trough zone because the paucity of historically recorded seismicity in this region precludes the determination of seismic activity rates for such faults. A single exception is an inferred north-northeast-trending fault that follows a steep bathymetric break at the Gulf of Suez-Red Sea junction. An $m_{b}=6$ earthquake occurred at this location on March 31, 1969 (Fairhead and Girdler, 1970; Ben-Menahem and Aboodi, 1971), and the zone, which has remained intermittently active, produced four earthquakes of $m_{b} \approx 4-4.5$ through 1984 . The zone's unique structural setting and continuing history of seismic activity distinguishes it from other inferred structures of the northern Red Sea. We have, therefore, represented this seismically active zone as a distinct seismic source.

\section{Gulf of Aden}

The Red Sea rift and the continental rifts of east Africa are joined to the worldwide rift system through the Sheba Ridge spreading center that extends the length of the Gulf of Aden (fig. 2). To the east, at about long $58^{\circ}$ E., Sheba Ridge is terminated by right-lateral transform slip along the Owens Fracture Zone. To the west, Sheba Ridge shoals into the Afar region of east Africa where its structural expression as a distinct ocean-spreading ridge is lost in a broad region of distributed extension (fig. 2). Geomorphic expression of Sheba Ridge narrows from a 

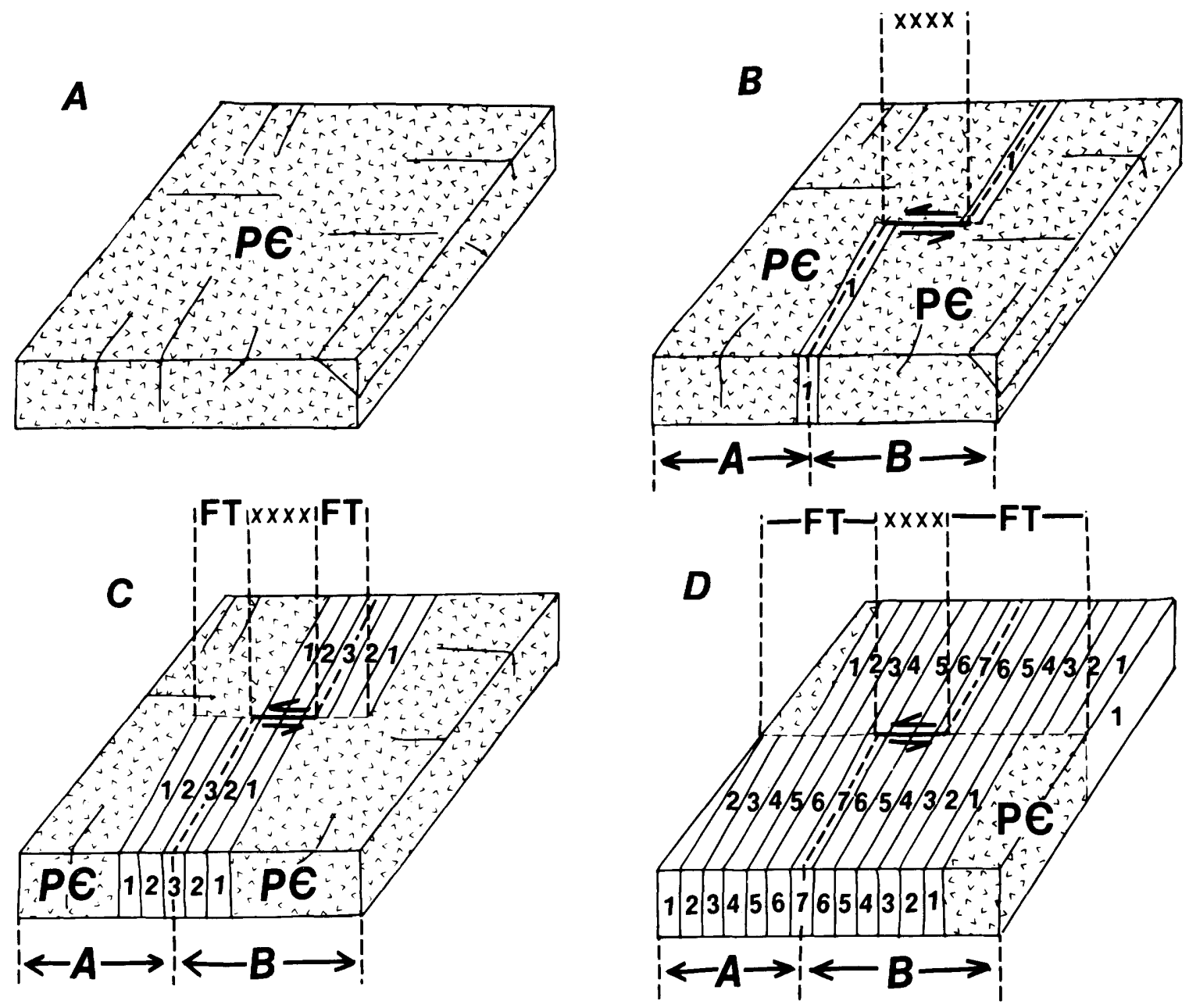

Figure 6. Schematic block diagrams showing formation of oceanic crust through rigid-plate rifting. $A$, Magnetic anomaly time, $T=0$. Precambrian crystalline crust with preexisting structural fabrics and faults. $B$, Magnetic anomaly time, $T=1$. Initial intrusion of oceanic crustal material along preexisting zones of weakness separates the Precambrian crust into blocks A and B. Dashed line indicates axial centerline of the new rift. Spreading is assumed to be symmetric to, and at a constant rate along, the rift axes. Creation of new crust across the right-hand offset of the spreading ridge is accommodated by left-lateral displacement along a transform fault. Zone of seismicity associated with transform movement extends between the spreading ridge axes and is shown by the line of "X' $\mathrm{s}$ " raised out of the plane of the diagram. $C$, Magnetic anomaly time, $T=3$. Continued symmetrical spreading along the rift axes, in time, results in accretion of young oceanic crust to blocks $A$ and $B$ and fossil transforms (FT) beyond the offset of the ridge axes. Note that the length of active transform faulting has not changed. Note also that fossil transforms have not formed through shear movement, but rather, through simple accretion juxtaposing crusts of different ages and composition. $D$, Magnetic anomaly time, $T=7$. Continued symmetrical rifting results in a broad area of oceanic crust. Note that the active zone of transform movement has not changed from diagram $B$. Further note the growth of fossil transforms from diagram $C$.

300-km-wide mountain range near the Owens Fracture Zone to a narrow valley occupying the Gulf of Tadjura, although expression of the axial valley does not greatly change (Laughton, 1966; Laughton and others, 1970). Numerous northeast-southwest-trending transform faults offset Sheba Ridge along its length (fig. 2); the most spectacular fault is the Alula-Fartak trench (Laughton, 1966) at long $52^{\circ} \mathrm{E}$. where Sheba Ridge is offset a distance of $160 \mathrm{~km}$. The transform is marked by a linear northeast-trending trench $240 \mathrm{~km}$ long, $16 \mathrm{~km}$ across, and 2,800 fathom deep (Laughton, 1966). Earthquakes associated with the trench show strike-slip mechanisms characteristic of oceanic transforms (Sykes and Landisman, 1964). Transforms and fracture zones of Sheba Ridge are typically characterized by linear northeastsouthwest-trending zones of mountainous topography as 
much as $16 \mathrm{~km}$ wide in the western gulf but considerably wider in the eastern gulf. Bouguer gravity anomalies, magnetic anomalies, and crustal velocities from seismicrefraction studies indicate Sheba Ridge is underlain by oceanic crust as much as 10 m.y. old (Girdler, 1970; Laughton and others, 1970; Cochran, 1981). Cochran (1982) suggested that there is a $80-\mathrm{km}$-wide zone of diffuse continental extension and mafic dike intrusion that extends to the Arabia coast beyond the 10-m.y. magnetic anomaly. Structure within this zone is suggested to have resulted from an early (10-15 m.y. ago) crustal stretching and attenuation episode that preceded ocean-floor spreading (Cochran, 1982).

Most of the seismicity of the Gulf of Aden shows a close spatial association with the axial valley of Sheba Ridge and associated transform faults (Fairhead and Girdler, 1970; McKenzie and others, 1970; Sykes, 1970; Sykes and Landisman, 1964; fig. 5). Some seismicity, however, occurs in the region of mountainous topography off the spreading axis and may be related to block adjustments in this region or a small amount of distributed ocean-floor spreading (Sykes and Landisman, 1964; Sykes, 1967). The largest earthquakes to occur in the gulf are associated with the Alula-Fartak transform zone. Magnitudes $\left(m_{b}\right)$ for events occurring in 1959 and 1967 were 6.7 and 5.8, respectively (Sykes and Landisman, 1964; Fairhead and Girdler, 1970).

Two seismic source zones have been constructed in the Gulf of Aden (fig. 3). A central rift zone collects seismicity occurring in close proximity to the axial valley. Near long $46^{\circ}$ E., a second, broader zone envelops the central rift zone and collects seismicity occurring within the broad area of mountainous terrain neighboring the central rift. The source zones terminate at the Owens Fracture Zone to the east. To the west, the central rift zone extends through the Gulf of Tadjurah into the Afar beyond Lake Asal to include the Ghoubbet-Asal rift and associated seismic activity (Abdallah and others, 1979). Westward, beyond Lake Asal, seismicity becomes diffuse and structural expression of a primary rift zone is obscured by significant distributed extension throughout the Afar.

\section{Fault-Source Model for Gulf of Aden}

As in the Red Sea fault-source model, spreadingridge earthquakes have been modeled as linear ruptures on faults placed parallel to, and $10 \mathrm{~km}$ either side of, the spreading axis of the Gulf of Aden (fig. 4). West of long $48^{\circ} \mathrm{E}$., transform offsets are numerous but very short, generally less than about $20 \mathrm{~km}$ (Cochran, 1981). Because such short rupture lengths would have no effect on ground-motion values onshore, they have not been modeled in this study. Between long $48^{\circ} \mathrm{E}$. and $54^{\circ} \mathrm{E}$. relatively long transform offsets of Sheba Ridge, including the Alula-Fartak trench, are present (Cochran, 1981). These longer offsets have been included in the fault model as northeast-southwest-trending faults that have linear earthquake ruptures (fig. 4).

\section{Afar Depression}

The Afar depression (fig. 2) of northeastern Ethiopia is the subaerially exposed structural junction of the Red Sea, Gulf of Aden, and East Africa rift systems. Because this unique tectonic setting provides direct observation of tectonic processes of a spreading-ridge triple junction, many diverse geologic investigations have addressed the structural and tectonic evolution of this region (see for example, Pilger and Rösler, 1975). To review the many significant contributions to the tectonics and structure of this region is beyond the scope of this investigation. Because our area of interest is the Arabian Peninsula, we are concerned here with only far-field effects of earthquakes originating within the Afar, and much detail that could perhaps be modeled in seismic sources specific to the Afar region would have no effect on earthquake ground motions at distances with which we are concerned. The seismic source zones are, therefore, derived from only regional aspects of the tectonic setting.

The central Afar is a highly extended region characterized by a thin crust of mafic composition, voluminous Quaternary tholeitic volcanism, and intense normal faulting along north-northwest and northwest trends (Barberi and Varet, 1977; Mohr, 1975; Morton and Black, 1975; fig. 2). The region is conterminous to the inland extension of Sheba Ridge to Lake Asal that has been proposed by Abdallah and others (1979) based on contemporary extensional tectonism observed in the Asal-Ghoubbet graben and an associated well-defined seismicity trend. Northwest of Lake Asal, in the central Afar, seismicity is diffuse and two focal mechanisms in the region indicate east-west-trending planes of strikeslip displacement (McKenzie and others, 1970). In microplate kinematic models proposed by Barberi and Varet (1977) and Le Pichon and Francheteau (1978), zones of northeast-trending shear accommodate transform motion between offset, northwest-trending zones of extension.

The metamorphic continental crust of the Danakil block (fig. 2) marks the northeastern boundary of the Afar. In many tectonic models of this region, the Danakil block is inferred to be a splinter of continental crust separated from continental crust of the Nubian and 
Arabian plates by oceanic crust of the Afar depression to the southwest and that of the Red Sea to the northeast (Le Pichon and Francheteau, 1978; Barberi and Varet, 1977; Hall, 1980). Offset of the primary locus of spreading from the southern Red Sea to the Afar is inferred to occur by means of a transform zone through the Dahlac Islands, north of the Danakil block, to the Gulf of Zula (fig. 2). In contrast to the aseismic appearance of the shelf areas of the southern Red Sea, an active seismic zone extends across the western shelf in the vicinity of the proposed transform (fig. 5). We have modeled this inferred transform zone as a fault-source for earthquakes in this region.

The western and southern boundaries of the Afar depression are marked by relatively narrow, bedrock escarpment terranes which are transitional zones between the structurally low, strongly faulted and extended central Afar region and the structurally high, slightly deformed regions of the Ethiopia and Somalian plateaus (fig. 2). Large-displacement normal faults and, in places, up-to-basin block rotations along (listric?) normal faults characterize the general structure of the escarpment terranes (Zanettin and Justin-Visentin, 1975; Juch, 1975; Gouin and Mohr, 1964). The escarpments converge to the southwest and follow the margins of the Ethiopian rift into the East African rift system.

A strong north-south seismicity trend has long been recognized along the length of the Ethiopian escarpment (Gouin and Mohr, 1964). Gouin (1970, 1979) found the Ethiopian escarpment to be the most seismically active zone in Ethiopia. Only a few epicenters occur in close proximity to the southeast escarpment, although the Aysha Horst, which bounds the extreme southeast Afar, appears to be associated with significant activity (fig. 5).

Our seismic source zones for the Afar region are quite general because we are only concerned with low levels of earthquake ground motions at large distances from earthquakes in this tectonically active region. The Ethiopia and southeast escarpments (including the Aysha Horst) comprise seismic source zones bounding the Afar region (fig. 3 ). The source zones are terminated at a rather arbitrary location to the southwest where they converge and funnel into the Ethiopian rift. At some point towards the southwest, presently undefined, it would appear that contemporary tectonism within the escarpments is no longer influenced by the distributed, extensional processes of the Afar but is more closely related to the tectonics of the Ethiopian rift.

The central Afar has been separated from areas to the north and south based on fault trends, intensity of tectonism, and a dispersed pattern of seismicity.
Dominant northeast and north-northeast fault trends of the southwestern Afar, which are associated with the intersection of the Ethiopian rift (fig. 2), have been excluded from the central Afar seismic source. No significant seismicity has been historically documented in this region. To the north, sparse seismicity of the Danakil block and Danakil depression have been excluded from the central Afar source zone.

\section{Western Arabian Peninsula}

Precambrian crystalline basement is widely exposed throughout western Saudi Arabia (fig. 2), although large areas are covered by voluminous Tertiary basalts. Three Precambrian tectonic provinces have been recognized in the structural framework of the shield (Greenwood and others, 1980). The Najd fault system is the most prominent structural feature of the Arabian shield and comprises the youngest of three Precambrian tectonic provinces (Greenwood and others, 1980). Shear zones of the Najd system separate the Hijaz-Asir province to the southwest from the Shammar province to the northeast (fig. 2). At least four major northwesttrending left-lateral wrench zones of the Najd cross the shield from the northeast coast of the Red Sea to the southeast shield area where the fault system is concealed beneath Mesozoic sedimentary rocks. Cumulative Precambrian left-slip on the Najd system is estimated to be about $240 \mathrm{~km}$ (Brown, 1972). Greenwood and others (1980) suggested that the Najd tectonic province is also structurally depressed because of the smaller area of exposed high-grade metamorphic rocks and larger area of unmetamorphosed rocks as compared to the neighboring Shammar and Hijaz-Asir provinces.

The Hijaz-Asir Precambrian tectonic province lies between the Najd fault system and the coastal plain (fig. 2). In the southeastern part of this province, braided north-trending fault zones predominate with complex patterns of left- and right-lateral, normal and reverse faulting (Greenwood and others, 1980). In the central part of the province, faults have a distinctive northeastsouthwest trend. The Ad Damm fault (fig. 2) is a prominent structure of this region and extends about 130 $\mathrm{km}$ to the northeast from the coastal plain to beyond Taif. Pallister (1984) has inferred right-lateral Precambrian movement on this fault. Significantly, Merghelani and others (1981) have noted a high level of contemporary microseismicity in the vicinity of the fault.

The Shammar tectonic province is exposed over a relatively small area of the extreme northeastern shield area and is characterized by north- and northeasttrending lineaments and granitic intrusions (Greenwood and others, 1980). 
Contemporary seismic activity in the shield area appears low as no significant earthquakes have been recorded in this area since the establishment of the WWSSN in the mid-1960's. However, historical accounts researched by Poirier and Taher (1980) indicate that strong earthquake shaking has been experienced at Khaybar, Tayma, and Yanbu in the year 1068 and Medina in 1122 and 1256 (figs. 2, 5). Taif experienced earthquake shaking in the year 1270 and Mecca in 1481. Detailed accounts for these events are not given by Poirier and Taher (1980); however, they did note that ground cracking and fissuring accompanied widespread destruction in Arabia in the 1068 event. They assigned a MMI of IX to these reports of shaking. The 1256 Medina event (MMI $=\mathrm{IV}$ ) is likely related to volcanic activity. Smoke was seen from Medina, and a lava flow approached the city. At present, lacking any further historical information and any field geologic investigations relating to the reported ground fissuring, the locations of the earthquakes that caused these reported shaking phenomena cannot be determined confidently. It may be reasonable to assume, however, that if the locations of ground disruption for the 1068 event (Khaybar and Tayma and presumably between these locations) approximate the epicentral region, this event was of tectonic origin as opposed to the apparent volcanic origin of the $1256(\mathrm{MMI}=\mathrm{IV})$ Medina event.

In contrast to the paucity of information related to historical earthquakes in western Saudi Arabia, Ambraseys and Melville (1983) have outlined a generally continuous record of moderate-sized earthquakes that occurred in Yemen over the past 12 centuries. Most recently, the December 13, $1982\left(M_{s}=5.7\right)$ earthquake near Dhamar, North Yemen, caused considerable destruction and loss of life (Arya and others, 1985). The earthquake occurred in an area of active extensional tectonism characterized by horst-and-graben structure and Holocene basaltic volcanism (Geukens, 1966).

The dearth of information concerning the historic and contemporary seismicity of the Arabian shield presently precludes any systematic seismotectonic analysis of the region. To construct seismic source zones for this region, therefore, we have imposed a hypothesis that relates any significant future earthquake activity in the shield to seismic reactivation of Precambrian faults. Thus, the source zones conform to Precambrian tectonic provinces and regional Precambrian structural trends. The approach is justified, in part, by studies of intraplate earthquakes in the United States (for example, Hamilton, 1981) and worldwide (Sykes, 1978) which concluded that there is fairly clear evidence for larger intraplate earthquakes to be caused by reactivation of ancient, Precambrian faults or fault systems. Some support for applying this approach to source zones on the Arabian Shield is lent by microseismicity studies of Merghelani
(1979, 1981) and Merghelani and others (1981). These studies suggest that microseismic epicenters are concentrated near structural lineaments of probable Precambrian origin and near Precambrian faults such as the northeast-trending Ad Damm fault near Taif. Speculatively, there may be an association between shaking felt at Taif in 1270 and Mecca in 1481 (Poirier and Taher, 1980) and the Ad Damm fault that is in close proximity to both of these locations. Incidental support of the approach to source zones comes from recognition of the profound role played by Precambrian faults and fault systems in the development and disposition of the east Africa rift system (McConnell, 1967, 1972; Harpum, 1970). However, the fact that the Red Sea rift cuts across major, northeast-trending Precambrian trends could perhaps be used as an argument against significant Tertiary structural control by Precambrian structure. At best, the Red Sea rift strikes parallel to a subordinate, relatively poorly developed north-northwest-trending system of short Precambrian faults and structural lineaments.

The Najd fault system comprises the northeasternmost zone of the study area (figs. 2,3). To the northwest, the Najd source zone is terminated by zones of the Dead Sea rift and Red Sea rift. To the southeast, the Najd source zone extends beneath Mesozoic sedimentary cover rock to include the terminous of the fault zone as depicted by Brown (1972). Included within the Najd zone are the historically reported shaking events near Medina, Kaybar, and Tayma (Poirier and Taher, 1980).

Southwest of the Najd fault system, the northeasttrending faults of the central Hijaz-Asir Precambrian tectonic province have been separated from the braided north- and north-northeast-trending faults of this province. The Ad Damm fault is a prominant feature of this northeast-trending zone.

In the southwestern portion of the Arabian Peninsula, the seismicity of the Yemen area is collected by a zone that is defined primarily by the regional exposure of the Yemen Trap Series volcanics. Although not explicitly keyed to structure, the zone as drawn is thought to include the primary region of significant contemporary extensional tectonism in the southwestern part of the Arabian Peninsula. The northern boundary is of utmost importance to the city of Jizan, Saudi Arabia; unfortunately, however, this boundary is poorly defined at present. Jizan has been included in the zone of relatively high seismic activity of North Yemen because of the January 11, 1941, earthquake $\left(M_{s}=5.8\right.$; Ambraseys and Melville, 1983) that occurred about $75 \mathrm{~km}$ east of Jizan near Riyah. The earthquake caused widespread damage in North Yemen; the earthquake was apparently felt without causing damage in Jizan. 
Table 1. Estimates of b-values using two maximum-likelihood techniques

\begin{tabular}{|c|c|c|}
\hline \multirow[t]{2}{*}{ Tectonic category } & \multicolumn{2}{|c|}{ Maximum-likelihood methods } \\
\hline & Fit to annual rates & Weichert (1980) method \\
\hline \multicolumn{3}{|l|}{ Oceanic } \\
\hline Transform......... & -0.92 & -0.89 \\
\hline Nontransform .... & -1.01 & -1.04 \\
\hline Continental............... & -0.89 & -1.02 \\
\hline Combined tectonic categories $\ldots \ldots \ldots \ldots$ & -1.00 & -1.11 \\
\hline
\end{tabular}

\section{EARTHQUAKE-RECURRENCE MODEL}

The worldwide earthquake catalog of the National Earthquake Information Service (NEIS), U.S. Geological Survey, served as the primary source for earthquake information in the region with entries crosschecked and additions made from other published seismicity studies in the region (Poirier and Taher, 1980; Ambraseys and Melville, 1983; Fairhead and Girdler, 1970; Sykes, 1970; Sykes and Landisman, 1964). Significantly more documentary work is required to ensure a complete historical catalog.

Fairhead and Girdler (1970) concluded that earthquakes of $m_{b} \geq 5.0\left(M_{s} \geqslant 4.8\right)$ and $m_{b} \geq 4.8\left(M_{s} \geqslant 4.5\right.$ were well detected in the Red Sea and Gulf of Aden, respectively, since the early to mid-1960's. Our analysis corraborates their work and indicates $20 \mathrm{yr}$ of complete reporting for events $m_{b} \geq 4.5$; earthquakes smaller than $m_{b}=4.5$ are not of interest in this study because they are not generally associated with damage to structures. Joint epicenter relocations by Fairhead and Girdler (1970) indicated that, for earthquakes occurring in the northern and central Red Sea between 1962 and 1968 and having magnitudes $m_{b} \geq 4.1$, epicentral locations in the catalog were in error by no more than $0.20^{\circ}$ in either latitude or longitude. In the southern Red Sea-northern Ethiopian region, one relocated epicenter shifted $0.6^{\circ}$ in latitude. The remaining relocations, however, were less than $0.35^{\circ}$. In the eastern Afar-Gulf of Aden region, one relocated epicenter shifted $0.46^{\circ}$ in longitude, but remaining relocations were less than $0.35^{\circ}$. Our conclusion is that epicenter locations as reported in NEIS catalog (formerly the U.S. Coast and Geodetic Survey catalog) through 1984 are adequate for a regional investigation where seismic sources correspond to regional geologic provinces. Further investigations of individual epicenters would be required for a study dealing with local, seismically active faults.
Measures of earthquake size appear in the catalog as body-wave magnitude $\left(m_{b}\right)$, surface-wave magnitude $\left(M_{s}\right)$, local magnitude $\left(M_{L}\right)$, and epicentral intensity $\left(I_{o}\right)$. For statistical analysis of earthquake recurrence frequencies, the various measures of earthquake size were converted to $M_{s}$ magnitudes. A least-squares regression fit to the catalog data gives the equation:

$$
M_{s}=1.36 m_{b}-2.02 \text {. }
$$

Similar fits to magnitude-intensity data of the catalog yield:

$$
M_{s}=0.6 I_{o}+0.85 \text {. }
$$

Fits of $M_{L}$ on $I_{o}$ gave results identical to $M_{s}$ on $I_{o}$ above, although the few earthquakes having $M_{L}$ measures are less than $M_{L}=5.5$. Catalog $M_{L}$ magnitudes were assumed to be equivalent to $M_{s}$ magnitudes.

This approach assumes similar source properties for all earthquakes, although such an assumption is probably not strictly correct considering the different tectonic settings represented in the earthquake catalog. Ground-motion amplitudes and predominant periods of ground motion for various magnitude measures are likely to vary among the tectonic environments. However, significantly more seismological research throughout the region is required to substantiate these variations and to allow a proper treatment of magnitudes and attenuation throughout the region.

\section{Seismicity Parameters}

Determination of constants $a$ and $b$ in the Richter relation of occurrence frequencies, $\log N=a+b M$, 


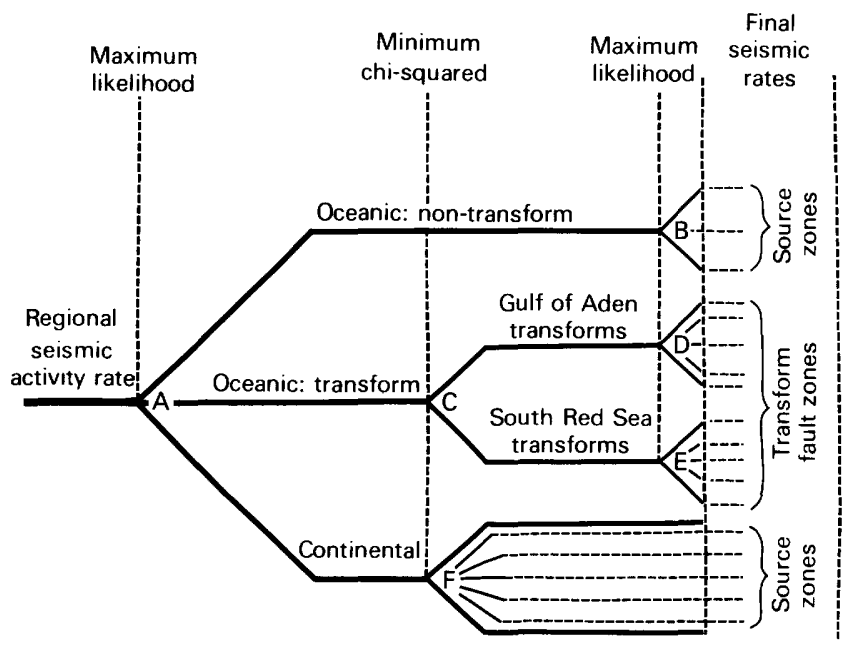

Figure 7. Allocation scheme of distributing regional seismic activity rate into constituent seismic source zones and faults. Steps labeled $A$ through $F$ correspond to descriptions of procedures in text.

followed from a series of statistical tests of the earthquake data base. The seismic source zones were classified into oceanic rifting and continental divisions to investigate the possible existence of statistically significant differences in $b$-values for various tectonic settings represented in the earthquake catalog. Oceanicrifting zones were subdivided into areas of transform faults and areas not having known or inferred transforms. In the Red Sea and Gulf of Aden, earthquakes located generally within $30 \mathrm{~km}$ of a known or inferred transform fault or transform zone were assumed to be associated with transform faulting. Time of complete earthquake reporting was estimated for both oceanic and continental earthquake catalogs according to the methods described by Stepp (1973) and Weichert (1980). Estimates of $b$-values of maximum-likelihood fits to the entire catalog data base and to subcatalogs are summarized in table 1 .

Bender (1983) has published curves showing 50 percent and 90 percent confidence regions for $b$-value fits to simulated seismicity data. As expected, when the numbers of earthquakes in a sample become smaller, the $b$-values have progressively larger confidence limits. For 40 earthquakes, about the number used in each tectonic category above, the 75th percentile and 25 th percentile $b$-value estimates lie at about 1.15 times $b$ and 0.87 times $b$, respectively (derived from fig. 5 of Bender, 1983). On this basis, we concluded that the data are insufficient to prove that the different tectonic categories have $b$-values different from that of the fit to the combined data set. Accordingly, we adopted one of the two maximumlikelihood fits to the combined data. We chose -1.00 from the maximum-likelihood fit to annual rates instead of the Weichert (1980) method because, although both techniques gave comparable values for predicted rates for modest-size earthquakes, the fit to annual rates results in rates about 50 percent higher for earthquakes in the magnitude 6.55-7.15 category. We decided to accept the more conservative value. However, because the hazard estimates are not critically sensitive to earthquake occurrence rates at high magnitudes, the choice of one over the other would not result in a significant difference in ground-motion values.

There are too few earthquakes to fit $a$-values for individual source zones or source faults; hence, it is necessary to allocate the seismicity from a regional seismic activity rate into the constituent source zones and faults. Two optimal ways for statistically performing this allocation exist: maximum-likelihood and minimum-chisquared procedures. For the maximum-likelihood technique of allocation, the rates are allocated according to the total number of earthquakes observed in a zone. This count is taken for earthquakes above some magnitude for which the seismicity of the regional source zones are determined to be complete.

Whereas the maximum-likelihood technique is insensitive to the magnitudes of the earthquakes observed in a zone, the minimum-chi-squared technique is not and gives somewhat higher allocations to zones in which higher magnitude events have occurred. Extensive testing with simulated data suggests that the minimumchi-squared technique may be superior to the maximumlikelihood technique when independence of earthquake occurrences within a zone is not assured and the occurrence of a high-magnitude event appears to inhibit the occurrence of subsequent lower magnitude events for the duration of the catalog. Furthermore, because of lower sensitivity to the occurrence of lower magnitude events, the minimum-chi-squared technique may be the preferred technique when there is a considerable difference in the completeness times of the lower magnitude categories. The maximum-likelihood technique, because it only depends on the number of earthquakes observed and not on their magnitude, overweights the contribution of small events.

For oceanic transform faults (sections D and E below) we assumed a priori that the rate per unit length among all the transform faults should be equal and chose the allocation technique that gave a reasonable approximation to that assumption. The calculated seismic rates for all sources are tabulated in the Appendix. 
Seismic-Rate Allocation

\section{Sequence and Methods}

Figure 7 schematically illustrates the various steps of the seismic rate allocation procedure. These steps, A through $\mathrm{F}$, are outlined below.

\begin{tabular}{l}
\hline Allocation \\
\hline Allocation of regional seismic Maximum likelihood. \\
activity rate into three \\
tectonic categories of zones: \\
oceanic nontransform zones, \\
oceanic transform zones, and \\
continental zones. \\
Comment: Seismicity rates resulting from this allocation for \\
magnitude-6.5 earthquakes are about 50 percent \\
higher than rates from direct fits to the seismicity of \\
the individual tectonic categories.
\end{tabular}

B. Seismicity rate of oceanic, Maximum likelihood. nontransform zones into northern and southern Red Sea zones and zones around Sheba Ridge in the Gulf of Aden.

C. Seismicity rate of oceanic, transform zones into overall rates for both the southern Red Sea and Gulf of Aden transforms.

Comment: Direct allocation into individual transform fault zones at this stage would have reduced the Red Sea transform rates by a factor of 2 overall and would have produced rates inconsistent with our assumption of equal-rate-per-unit-fault-length.

D. Overall seismicity rate for Maximum likelihood Gulf of Aden transforms into (best conformance equalindividual transform faults.

rate-per-unit-fault-length assumption).

E. Overall seismicity rate for southern Red Sea transforms into individual transform faults.

Maximum likelihood (best conformance with our equalrate-per-unit-fault-length assumption).

F. Overall seismicity rate for the continental tectonic category into individual source zones.

Minimum chi-square (unequal completeness)

Comment: Eight zones are assigned approximately the same rates under either maximum-likelihood or minimum-chi-squared allocation; four zones had allocated rates varying between 0.5 and 3 times the rate allocation from the maximum-likelihood method.

\section{Maximum Magnitudes}

For each seismic source zone, an estimate of the maximum possible size of potential earthquakes is required to truncate the exponential frequency distribution. Due primarily to the lack of insight into distinctions in potential earthquake-source dimensions among many of the seismic source zones, maximum magnitudes were assigned to broad geologic categories of source zones. The highest maximum magnitude $\left(M_{s}=8.0\right)$ was assigned to the three segments of the Dead Sea transform on the basis of the historical occurrence of an estimated $M_{s}=8.0$ on the northern segment (Ben-Menahem, 1981). Long fault lengths and historical occurrences of earthquakes having estimated magnitudes $\geq 7.0$ in the central and southern segments (Ben-Menahem, 1981) were the bases of assigning a maximum magnitude $M_{s}=8.0$ to these segments.

The maximum magnitude assigned to seismic source zones of the Red Sea and Gulf of Aden is $M_{s}=6.5$. Spreading ridge faults (located $10 \mathrm{~km}$ off the ridge axes) similarly are assigned $M_{s}=6.5$. This estimate is about one magnitude unit higher than the highest instrumentally determined magnitudes for earthquakes that could not be confidently associated with known or inferred transform faults. The corresponding $m_{b}$ magnitude is about 6.25 which fits well with Solomon and Burr's (1979, fig. 1) nominal upper bound for spreadingridge-axis earthquakes on ridges with half-spreading rates of $0.6 \mathrm{~cm} / \mathrm{yr}$ (the estimated half-rate of the Red Sea spreading ridge).

Oceanic transforms, on the other hand, were assigned a maximum magnitude of $M_{s}=7.2$. This estimate is based on the 1959 occurrence of an $m_{b}=6.7$ $\left(M_{s}=7.1\right)$ earthquake on the Allula-Fartak transform in the Gulf of Aden (Sykes and Landisman, 1964). Because the remaining oceanic transforms in the Red Sea and Gulf of Aden are considerably shorter than the AllulaFartak zone, this size event might be considered an overestimate of the maximum potential earthquake for these transforms. However, complicating any simple relation between transform length and earthquake size are observations by Burr and Solomon (1978) and Solomon and Burr (1979) that maximum moments, average fault width, and maximum moment sum increase with decreasing spreading velocities. From the empirical relations of Solomon and Burr between full spreading rate and moment for transform fault earthquakes, $M_{s}=7.2$ may underestimate the maximum-magnitude earthquake by about 0.25 magnitude unit. The spreading rate of the Red Sea rift would plot as a low extreme to their data base derived from worldwide examples of mature spreading ridges. It is not clear whether their empirical relations are valid for the poorly developed transform zones of the Red Sea spreading ridge.

The remaining zones of western Saudi Arabia, the Afar region of Ethiopia, and northeastern Egypt were also assigned maximum magnitudes of $M_{s}=7.2$. This value is about one magnitude unit higher than historically reported intensities (converted to $M_{s}$ ) or instrumentally recorded events in any of these regions. 
The ground-motion estimates of this study are not critically sensitive to the choice of maximum magnitudes. Because of the low rate of seismic activity in the region, the mapped ground-motion values are well below the near-field ground motions produced by the chosen maximum-magnitude earthquakes. Hence, the mapped ground motions are dominated by the more frequent occurrence of low- to moderate-magnitude events. At longer return periods than addressed here, where ground motions approach those produced by the maximummagnitude earthquakes, choice of upper-bound earthquakes becomes a critical factor in determining ground-motion levels (Bender, 1984b).

\section{MODELING EARTHQUAKE EVENTS}

Earthquakes are assumed to be equally likely throughout a zone and are modeled as point sources or as line sources of a length appropriate to magnitude/fault-rupture-length relations (Mark and Bonilla, 1977; Mark, 1977). Area seismic sources in this study are characterized by a low rate of earthquake activity; hence, all earthquakes in these sources are modeled as point sources. Acceleration values in zones of low seismicity are correspondingly low at the return period addressed here, even when maximum magnitudes are high. Because these low accelerations affect large areas, the ratio of the isoseismal area to the size of the linear earthquake source is large, and a point-source approximation can be justified (Bender, 1982, 1984b). However, in seismic source zones having relatively moderate to high rates of earthquake activity, modeling the larger earthquakes as linear ruptures is warranted and results in near-source ground-motion levels substantially higher than for point-source models (Bender, 1982, 1984b). This is the case for the rift axes and transform faults of the study.

A distinction was maintained in modeling earthquakes on the continental transform faults (Dead Sea Rift system) and the oceanic transforms (southern Red Sea and Gulf of Aden). Whereas the seismicity on continental transforms was modeled as a mixed-source type, that is, moderate to large earthquakes were modeled on faults and small earthquakes were modeled as point sources in an area around the faults, the oceanic transforms were modeled exclusively as fault sources. This modeling distinction was maintained, in part, because of tectonic dissimilarities between the two types of transforms, but also because of extreme differences in size of the transform zones relative to the map scale being used here. Active fault deformation associated with large transform plate boundaries through heterogeneous continental crust can seldom be confined to a single, narrowly confined fault strand. The preceding discussions of the Dead Sea transform illustrate this point for that region. On the other hand, small offsets of young oceanic spreading ridges define only a very restricted area where earthquakes related to rigid-plate transform faulting would be expected. On the regional scale of mapping being performed here, that area approaches a short linear source. Hence, representation of any area source becomes unimportant to the groundmotion hazard estimate.

\section{GROUND-MOTION ATTENUATION}

A number of aspects of the gross crustal structure in western Saudi Arabia and the eastern Red Sea lead us to believe that attenuation of ground motions from earthquakes in this region may present a difficult problem. As there are no seismograph or strong-motion records from moderate-sized events, there is no direct data on strong-ground-motion attenuation characteristics in western Saudi Arabia. Hence, an attenuation model developed outside of the region must be applied, but this can only be justified if it can be demonstrated that the tectonic settings are generally similar. This becomes a difficult proposition in view of the uncertainty concerning the tectonic history, crustal composition, and structure of the Red Sea rift.

Studies of attenuation of shear waves in the oceanic crust from a small number of earthquakes indicate very poor propagation (very low Q) for source-to-site paths crossing, or originating near, oceanic spreading ridges, due to the presence of high heat flow and partial melt immediately beneath the spreading ridge (Molnar and Oliver, 1969; Solomon, 1973). However, for some earthquakes on transform faults, source-to-site paths that do not cross spreading-ridge axes are characterized by efficient transmission of shear waves (generally high Q) (Molnar and Oliver, 1969; Solomon, 1973). Observations from different transform faults may not be directly correlative, however, because of the diversity of crustal structural and magmatic activity among oceanic transforms (Stewart, 1983). Efficient transmission of the $S_{n}$ (short-period shear waves) phase has been recognized across passive continental margins despite considerable lateral variations in crustal structure, composition, and thickness (Molnar and Oliver, 1969).

The coastal region of Saudi Arabia, where the largest population centers are located, is the most important region in this study. At question are the attenuation characteristics along source-to-site paths from the eastern Red Sea to the coastal area where the propagation path does not cross the spreading-ridge axis and from the Arabian shield area westward where the propagation path crosses abrupt lateral changes in crustal thickness and structure. 

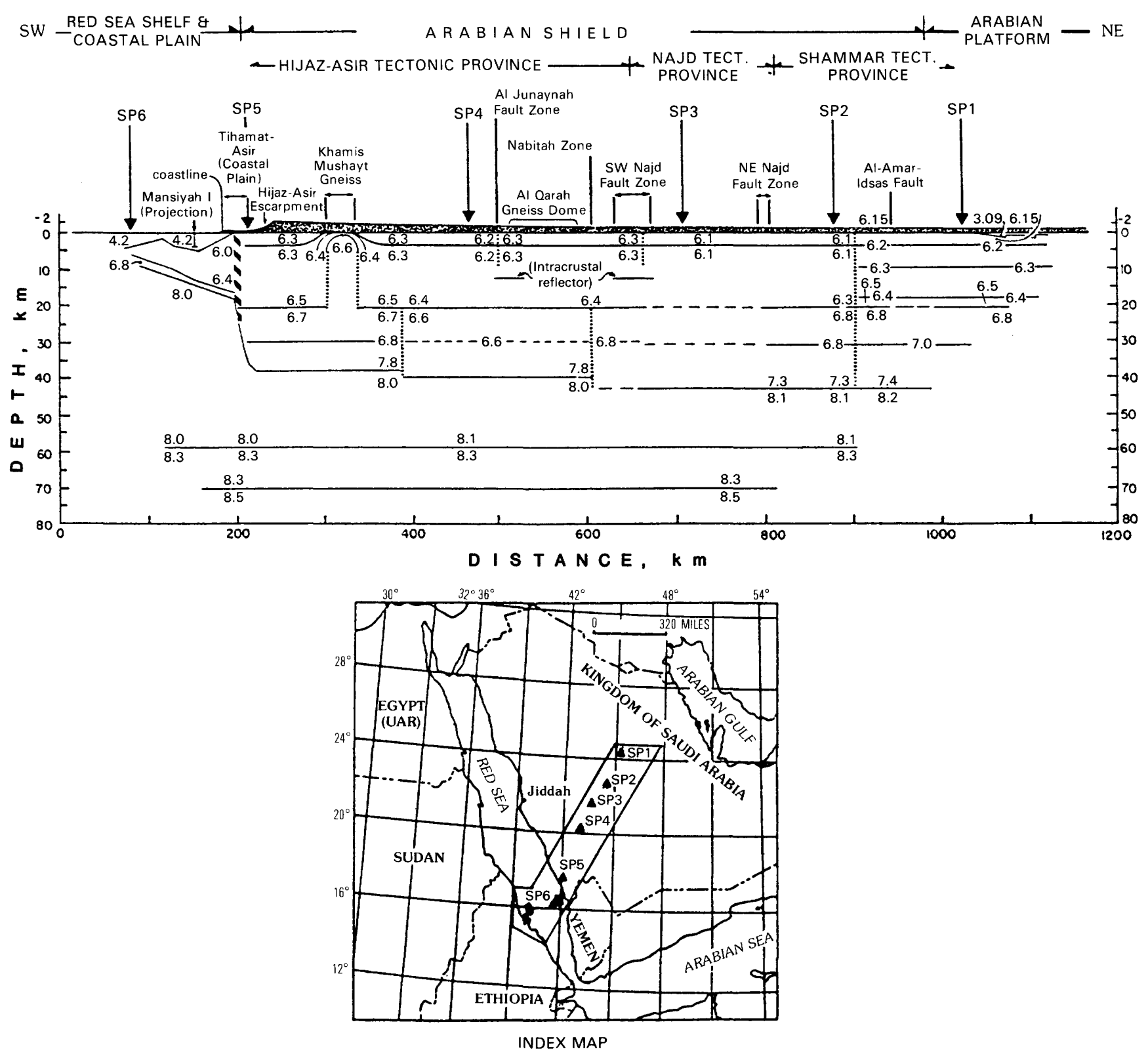

Figure 8. Interpreted velocity structure along the southwestern Saudi Arabian geophysical transect and seismic deeprefraction line (from Gettings and others, 1983).

The Red Sea is generally characterized by high heat flow. Measured heat flow values in the axial trough of the southern Red Sea range as high as 5 HFU (1 $\mathrm{HFU}=1 \times 10^{-6} \mathrm{cal} / \mathrm{cm}^{2} \mathrm{sec}$ ), which is somewhat more than three times the worldwide mean, and apparently decrease rapidly beneath the shelf to about 2 HFU at the coast (Gettings and others, 1983). High heat flow typifies regions of the world that are known to have high attenuation (low Q). Lithospheric strength, however, has been suggested as correlating with low attenuation (high Q) (Oliver and Isacks, 1967; Molnar and Oliver, 1969). Interpretations of a seismic deep-refraction line across the southern Arabia shield, coastal plain, and shelf indicate a shallow mantle and a high-velocity crustal wedge beneath the shelf that thickens rapidly to $20 \mathrm{~km}$ beneath the coastal plain where the wedge is in abrupt vertical contact with nearly normal shield-type crustal structure (Mooney and others, 1985; Gettings and others, 1983) (fig. 8). The high-velocity wedge is inferred to be mafic crust emplaced through either ocean-floor spreading or extensive diking in the early history of Red Sea rifting 20-25 m.y. ago. It is not clear at present what effect this high-velocity, presumably high strength, oceanic crustal wedge would have on propagation paths 
of earthquake waves originating in the eastern Red Sea or along transform faults within this region of moderate to high heat flow.

Propagation paths that trend east to west, from the shield area to the coastal plain, would seemingly best be described by an attenuation function incorporating low earthquake-wave attenuation (high Q), which is typical of shield areas worldwide. However, some areas of the shield, north of the refraction line traverse, are characterized by generally north-south trending zones of extensive Tertiary and Holocene basaltic volcanism. High heat flow and partial melts at all crustal levels in these volcanic zones could substantially alter attenuation characteristics for propagation paths that cross them. The abrupt lateral and vertical change in crustal structure beneath thick unconsolidated sediments of the coastal plain raises further questions of possible focusing effects and (or) amplification of earthquake waves in the coastal plain region.

In light of the uncertainties outlined above, we have investigated the consequences of modeling both low-Q and high-Q attenuation functions for all the seismic source zones. We consider the ground motions derived from the high-Q attenuation function as generally upper bound values for the seismic source zones and seismic activity parameters of this study. There appears to be a good possibility that future research could justify the use of at least two attenuation functions: possibly a low-Q attenuation for zones of the Red Sea rift and a high-Q attenuation for the zones of the shield area. At present, however, pertinent data are too sparse to justify adding this complexity to the model.

Figures 10 and 11 are profiles of ground-motion values calculated along lines extending from the Red Sea axial trough into the western Arabia shield (fig. 9). The figures summarize the range of ground motions calculated at Yanbu, Jiddah, and Jizan and apply various assumptions in two attenuation models that pair peak horizontal ground acceleration and peak horizontal ground velocity. Whereas peak acceleration values usually occur at ground-motion frequencies of about 5 $\mathrm{Hz}$, peak velocity values generally occur at frequencies of about 1-2 Hz. Therefore, velocity is generally a better measure of ground motion for applications concerned with long-period ground motions, such as earthquake effects on tall structures or high-rise construction located some distance from an earthquake source (see Steinbrugge, 1984, for discussion of some examples). Acceleration, on the other hand, provides a better measure of ground motion at the higher frequencies experienced closer to the earthquake source and is generally better suited to considerations involved in low-rise construction.
The attenuation models used in this investigation are those of Nuttli and Herrmann (1984) and K.W. Campbell (written commun., 1984; 1987) that are derived using arithmetic mean peak values for the two horizontal components of strong ground motion. Nuttli and Herrmann's (1984) attenuation model is based on a semitheoretical approach that incorporates a small amount of strong-motion data from small earthquakes in the upper Mississippi embayment and Atlantic coastal plain of the Eastern United States and theoretical relations between $m_{b}$ and far-field accelerations and velocities in a high-Q region. The relations are valid for $4.5 \leq m_{b} \leq 7.4$. Because the NEIS catalog data was previously converted to $M_{s}$ magnitudes for seismic rate determinations, a table of acceleration values as a function of $m_{b}$ and epicentral distance was constructed using Nuttli and Herrmann's attenuation model. $M_{s}$ magnitudes corresponding to Nuttli and Herrmann's $m_{b}$ magnitudes were then determined using $M_{s}=2.0 m_{b}-5.6$ (Nuttli, 1983), which holds for $4.5 \leq m_{b} \leq 7.0$ (the range of magnitudes of significance in this study). Groundmotion values associated with catalog $M_{s}$ values at various distances were then determined by interpolation in the table.

Nuttli and Herrmann's (1984) attenuation relations are developed for thick unconsolidated or stiff soil sites typical of the Mississippi embayment and coastal plain regions of the Eastern United States; a surficial geologic setting grossly similar to the coastal region of western Saudi Arabia. $\mathrm{Q}$ at $1 \mathrm{~Hz}$ is taken as 1,500 in their relations. For $m_{b} \geq 4.5$, their relations for average mean peak horizontal acceleration $\left(A_{h}\right.$, in $\left.\mathrm{cm} / \mathrm{sec}^{2}\right)$ and velocity $\left(V_{h}\right.$, in $\left.\mathrm{cm} / \mathrm{sec}\right)$ are of the form:

$\log A_{h}=A+0.50 m_{b}-0.83 \log \left(R^{2}+h^{2}\right)^{3 / 2}-B R$, and

$\log V_{h}=C+1.00 m_{b}-0.83 \log \left(R^{2}+h^{2}\right)^{1 / 2}-D R$,

where $A$ and $C$ are constants setting the level of the ground-motion curves for median values determined from available data for the Mississippi Valley, $R$ is epicentral distance, $h$ is minimum focal depth dependent on magnitude and given by $\log h_{(\text {min })}=-1.730+0.456 m_{b}$ for $m_{b} \geq 4.5$ (Nuttli, 1983), and $B$ and $D$ are equivalent to coefficients of anelastic attenuation in the Mississippi Valley region. The specific relations, given by Nuttli and Herrmann (1984) are:

$$
\log A_{h}=0.57+0.50 m_{b}-0.83 \log \left(R^{2}+h^{2}\right)^{1 / 3}-0.00069 R,
$$

and

$\log V_{h}=-3.60+1.00 \mathrm{~m}_{b}-0.83 \log \left(R^{2}+h^{2}\right)^{1 / 2}-0.00033 R$. 


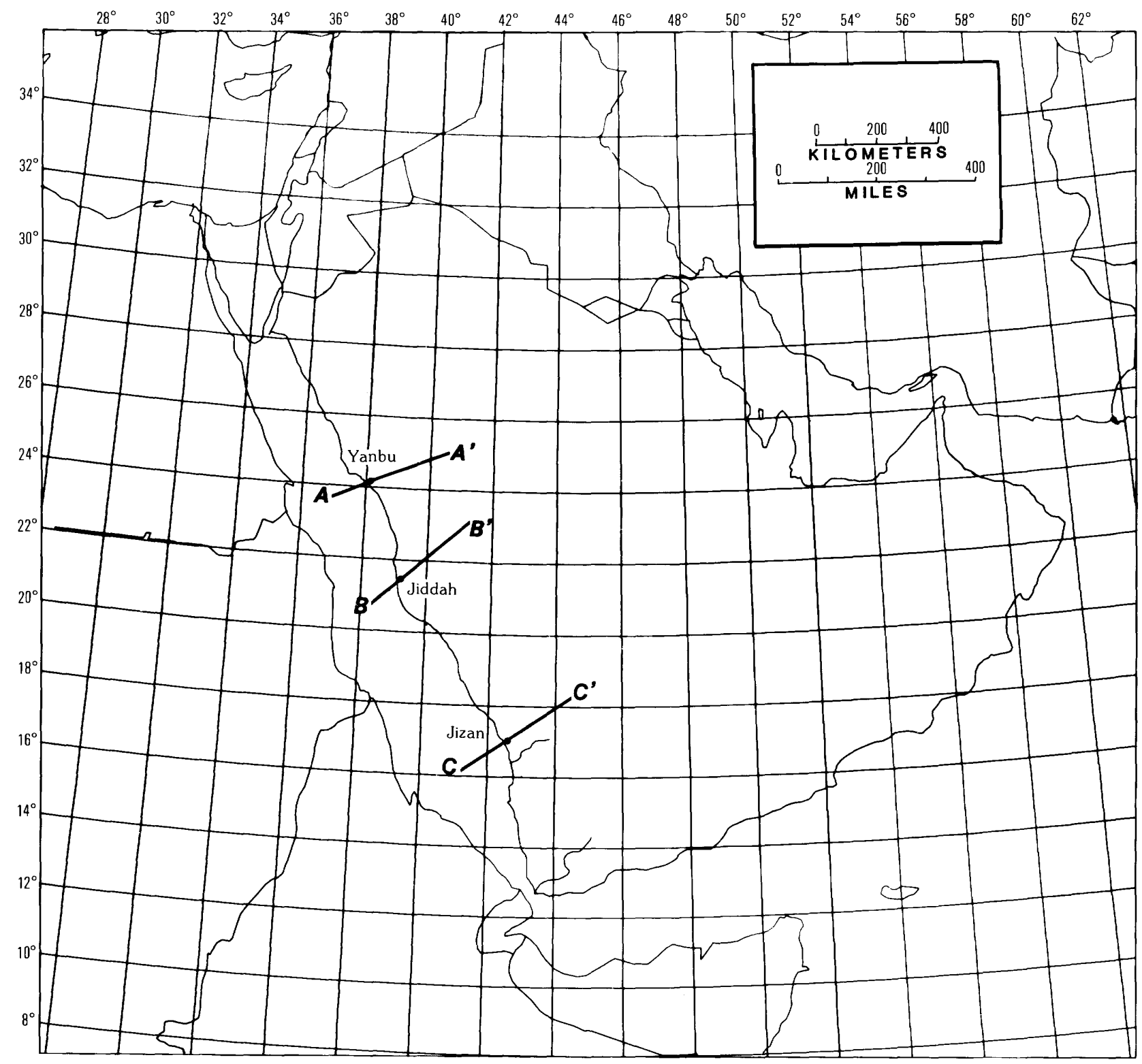

Figure 9. Index map showing the location of three ground-motion profiles depicted in figures 10 and 11 .

In our application of these attenuation relations, focal depths $(h)$ for earthquakes of all magnitudes have been held constant at $5 \mathrm{~km}$. We did this for two reasons. First, Nuttli and Herrmann's (1984) attenuation relations are developed for an intraplate seismic zone that might have nucleation depths for large earthquakes down to a $40-\mathrm{km}$ depth, which is the approximate base of the continental crust in the Central United States. Such depths for earthquake nucleation in the Red Sea are unreasonable. Second, because of the lack of strongmotion data and large uncertainty in characterizing the nature of ground-motion attenuation along the Red Sea coast, we wanted an upper-bound estimate of ground motion, given the seismic source zones and seismic activity rates of this study. The above treatment of the Nuttli and Herrmann (1984) attenuation relationships provides such an estimate.

The second set of attenuation models for mean peak horizontal acceleration and velocity were obtained from K.W. Campbell (written commun., 1984; 1987) and follow the form

$$
\ln Y=a+b M-d \cdot \ln \left[R+c_{1} \exp \left(c_{2} M\right)\right]+\Sigma e_{i} K_{i}+\epsilon,
$$

where $Y$ is the peak ground-motion parameter, $M$ is the magnitude $\left(M_{L}\right.$ for $M<6.0$ and determined by 

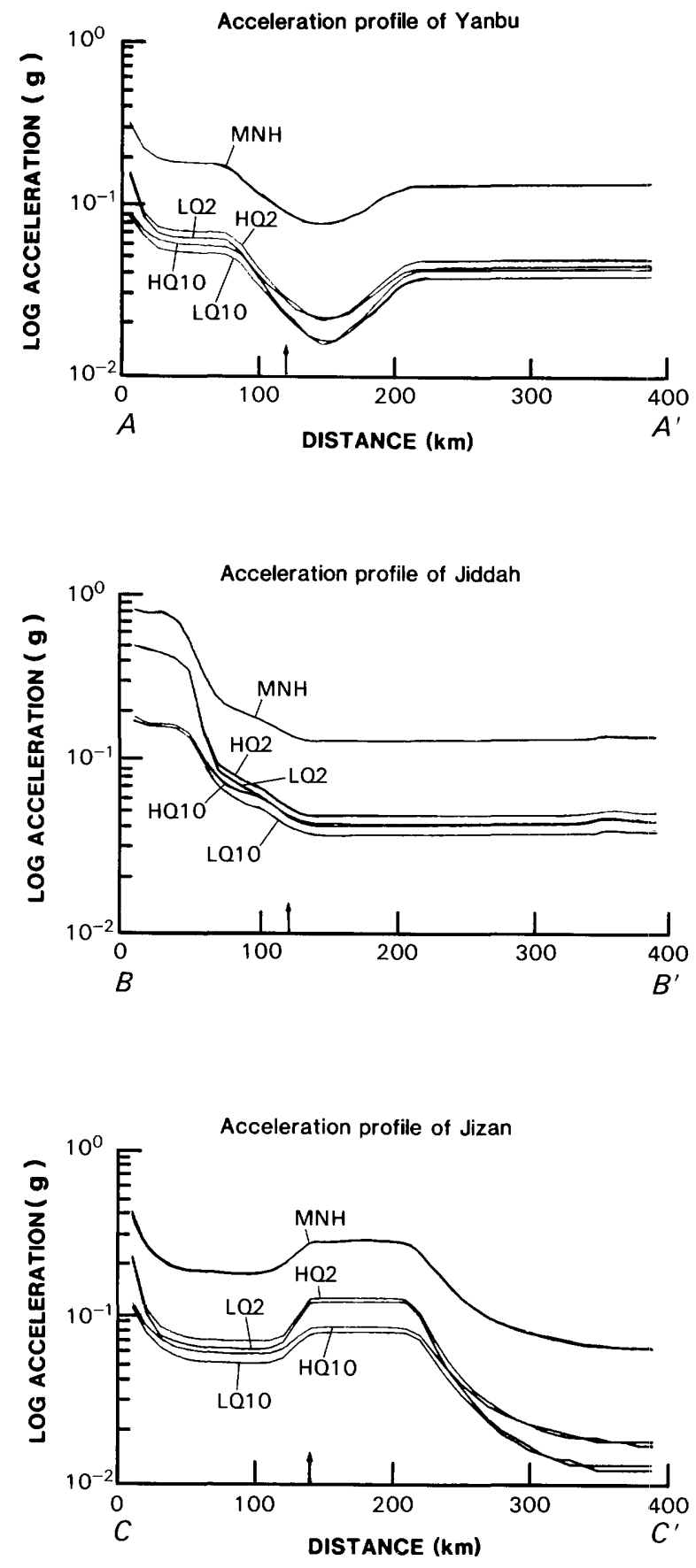

Figure 10. Profiles of peak horizontal acceleration along transects shown in figure 9 applying various assumptions to two attenuation models. Vertical arrows indicate the locations of the cities of Yanbu, Jiddah, and Jizan along their respective profiles. $\mathrm{MNH}=$ modified Nuttli and Herrmann (1984) attenuation relation (focal depths have been held constant at $5 \mathrm{~km}$ ). HQ2 and LQ2 = K.W. Campbell's (written commun., 1984) attenuation relation incorporating high-Q and low- $Q$ values, respectively, assuming a $2 \cdot \mathrm{km}$ depth to the top of the seismogenic zone (assumed top of crystalline basement). HQ10 and LQ10 = K.W. Campbell's (written commun., 1984) attenuation relation incorporating high-Q and low- $Q$ values, respectively, assuming a $10-\mathrm{km}$ depth to the top of the seismogenic zone.
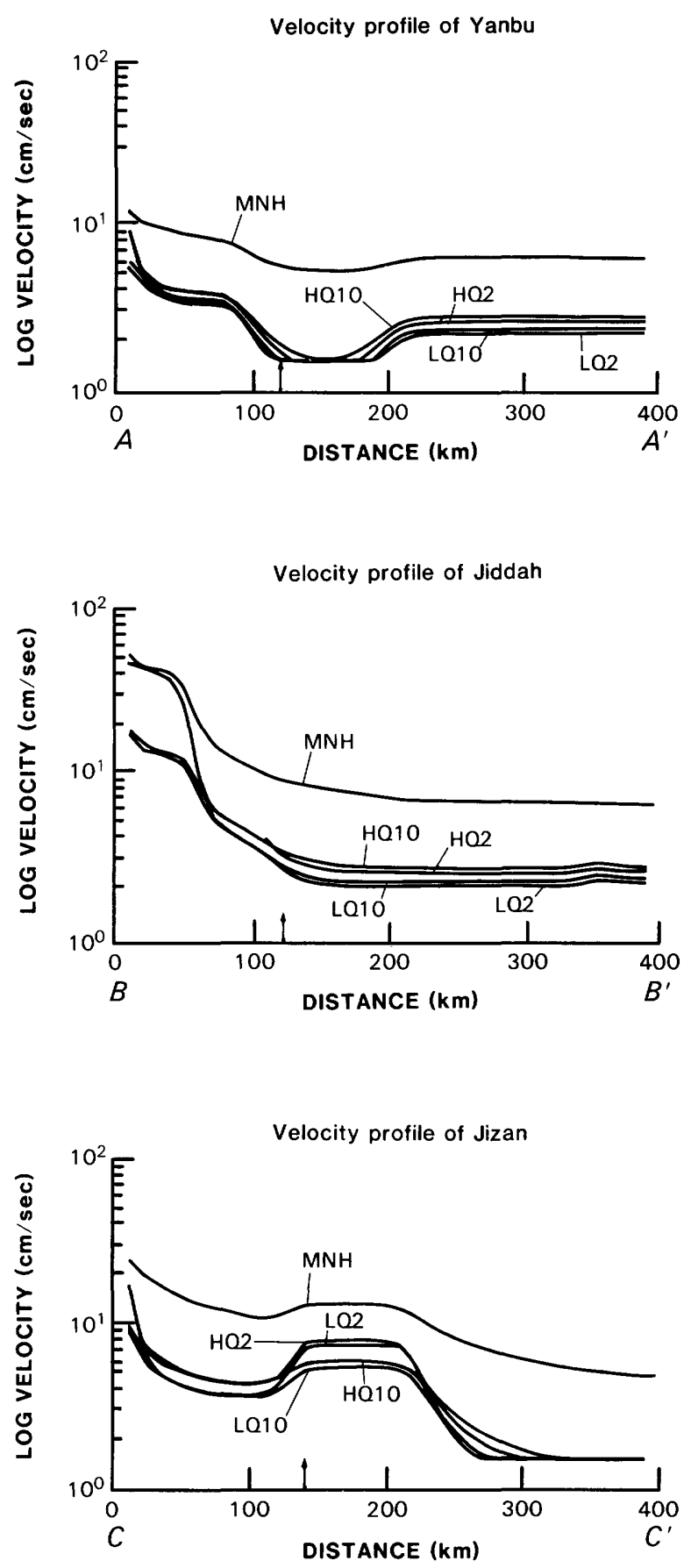

Figure 11. Profiles of peak horizontal velocity along transects shown in figure 9 applying various assumptions to two attenuation models. Labels are as in figure 10.

$M_{L}=2.241+0.621 M_{s}$ from Western United States data, K.W. Campbell, written commun., $1984 ; M_{s}$ for $M \geq 6.0$ ), $R$ is the shortest distance between the site and the seismogenic zone of rupture, $K_{i}$ is a set of source and site variables, and $\epsilon$ is a random error term (Campbell, 1981, $1982,1983,1984)$. The coefficents $a$ through $e$ are parameters determined from the strong-motion data 
base. $K_{i}$ variables are site parameters, $H$, which is thickness of surficial sediments, and $F$, which is fault type. For this study, depth of surficial sediments was taken to be $2 \mathrm{~km}$ along the coastal plain and all fault parameters are taken as normal faulting. The specific relations used in this study for peak horizontal acceleration $(P H A$, in $\mathrm{cm} / \mathrm{sec}^{2}$ ) and velocity $(P H V$, in $\mathrm{cm} / \mathrm{sec})$ were (K.W. Campbell, written commun., 1984; 1987):

$$
\begin{gathered}
\ln P H A=-3.303+0.85 M-1.25 \ln \left[R+0.0872 e^{0.678 M}\right]+ \\
0.34 F-0.0059 R, \text { and }
\end{gathered}
$$

$$
\begin{gathered}
\ln P H V=-1.584+1.18 M-1.24 \ln \left[R+0.00907 e^{0.951 M}\right]+ \\
0.49 F+0.534 \tanh (0.415 H)-0.0059 R .
\end{gathered}
$$

The relations are derived from worldwide strongmotion data and incorporate California-type anelastic attenuation in which $Q$ corresponds to 180 at $1 \mathrm{~Hz}$ (Joyner and Boore, 1981). Four profiles of ground motions (figs. 10, 11) were generated using Campbell's relations incorporating high- and low-Q values and 2and $10-\mathrm{km}$ depths to top of crystalline basement. Top of crystalline basement is taken to be the top of the seismogenic zone of rupture from which source-to-site distances are measured. This measure of distance is appropriate for moderate to large earthquakes where fault rupture may extend to the surface, because it is unlikely that the small stresses associated with rupture within the sedimentary section would contribute significant energy to surface ground motions (Campbell, 1984).

Figures 12 and 13 illustrate the low and high extremes in the attenuation relations used in this study. With focal depth constant at $5 \mathrm{~km}$ and high $\mathrm{Q}$, Nuttli and Herrmann (1984) relations result in extremely high ground motions for moderate to large earthquakes. We feel that ground-motion values derived from these curves are upper-bound ground-motion estimates given the consituent source zone and fault models of this study.

The lower curves at any given magnitude (figs. 12, 13) were estimated from K.W. Campbell's (written commun., 1984; 1987) attenuation relations incorporating low Q (high attenuation) and a 10-km depth to the top of the seismogenic zone (in this application, the top of crystalline basement). Curves for Campbell's attenuation relations assuming high $\mathrm{Q}$ and a $10-\mathrm{km}$ depth, and both high and low $Q$ at a $2-\mathrm{km}$ depth, fall between these two sets of curves in figures 12 and 13.

\section{Preferred Attenuation Model}

Our preferred interpretation of ground-motion attenuation in coastal Saudi Arabia, based on presently available data, is given by Campbell's low-Q, 2-km-depth attenuation models for acceleration and velocity. Attenuation curves for these models are shown in figures 14 and 15. A low-Q model is preferred because of high shallow-crustal temperatures in and along the Red Sea rift. As previously mentioned, heat flow measurements across the southern Red Sea coast range from as high as $5 \mathrm{HFU}$ in the axial trough to $2 \mathrm{HFU}$ at the coast (Gettings and others, 1983). In comparison, heat flow values for the Western United States, a region known to have high attenuation (low $Q$ ), is generally characterized by values $\geq 1.5 \mathrm{HFU}$ (Diment and others, 1975). In contrast, the Central and Eastern United States, known to be regions of low attenuation (high $Q$ ), are characterized regionally by values $\leq 1.5$ HFU (Diment and others, 1975).

\section{GROUND-MOTION HAZARD MAPS}

Figures 16 and 17 show the regional distribution of peak acceleration and velocity having a 0.90 ( 90 percent) probability of not being exceeded in $100 \mathrm{yr}$ for the preferred attenuation model. The highest predicted ground-motion values occur in extreme northwestern Saudi Arabia neighboring the Gulf of Aqaba. Accelerations as high as $0.30 \mathrm{~g}$ and velocities as high as $21 \mathrm{~cm} / \mathrm{sec}$ are predicted and are governed by the faultsource model, the moderate rate of earthquake activity, and the potential for large earthquakes in the Gulf of Aqaba The town of Haql, located on the northeastern shore of the gulf is included in this region of comparatively high ground motion. Ground-motion values in coastal regions neighboring the Red Sea range from $0.05 \mathrm{~g}$ and $2 \mathrm{~cm} / \mathrm{sec}$ at $Y a n b u$, and $0.07 \mathrm{~g}$ and 4 $\mathrm{cm} / \mathrm{sec}$ at Jiddah, to $0.13 \mathrm{~g}$ and $7 \mathrm{~cm} / \mathrm{sec}$ at Jizan. The ground-motion values at Yanbu and Jiddah are governed by the seismic sources of the central Red Sea. The seismic source zones corresponding to the Precambrian shield tectonic provinces (figs. 2,3 ) have a low rate of earthquake activity and result in relatively low ground motions of around $0.04 \mathrm{~g}$ and $2 \mathrm{~cm} / \mathrm{sec}$ over broad inland areas. The higher ground motions toward the coast at Yanbu and Jiddah are a result of distant ground motions from more frequent, larger earthquakes in the central Red Sea fault zones. The ground motions predicted at 


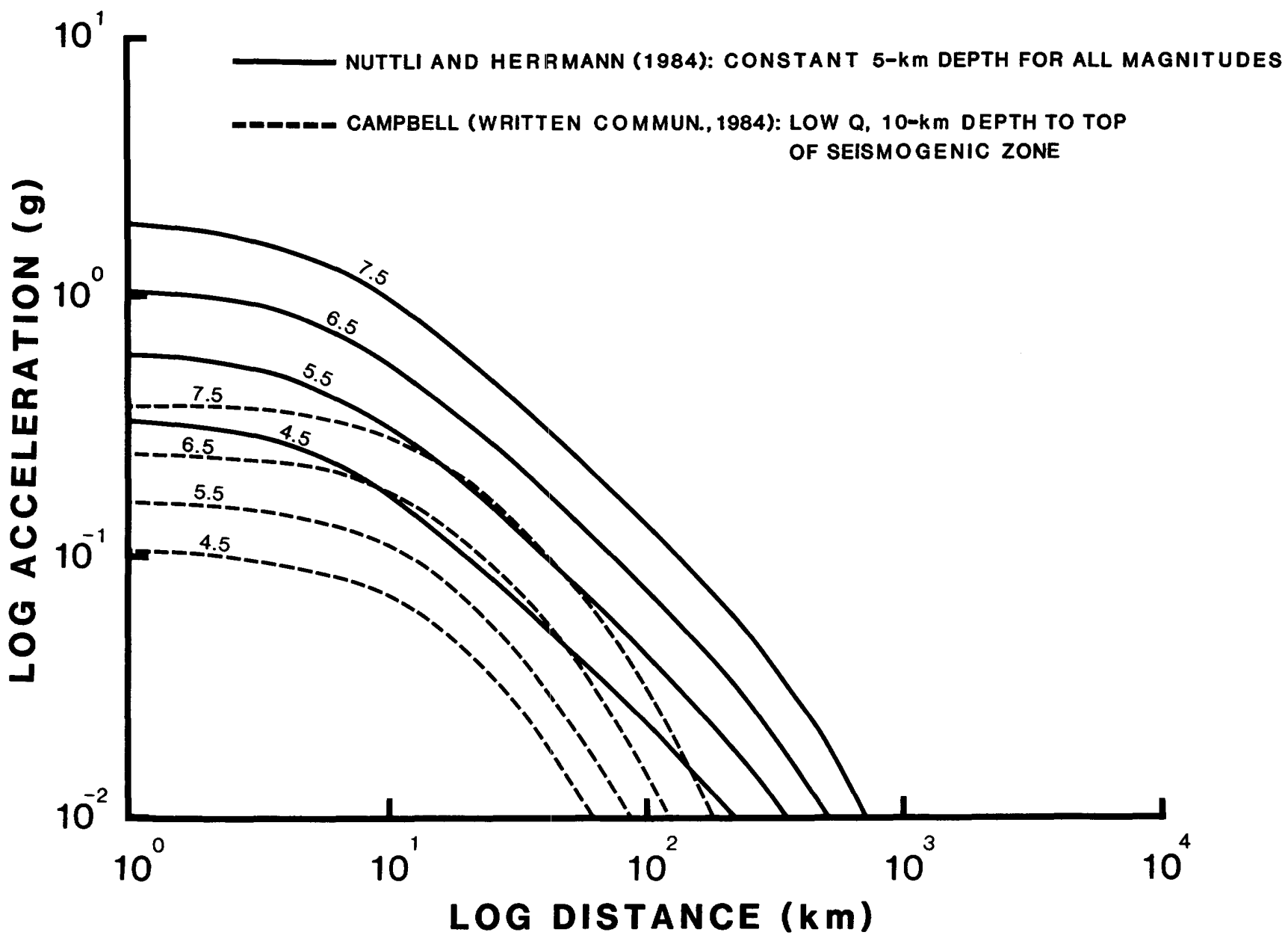

Figure 12. Acceleration attenuation curves illustrating the high and low extremes of attenuation relations investigated in the study. Magnitudes are $M_{s}$ for Nuttli and Herrmann (1984) curves and $M_{s}$ for $M \geq 6, M_{L}$ for $M<6$ for Campbell curves (written commun., 1984). See text for treatments of magnitude measures in the attenuation functions. Distance is epicentral distance for Nuttli and Herrmann curves and closest distance to the seismogenic zone of rupture for Campbell curves.

Jizan, however, are not a result of seismic activity modeled in the central Red Sea but rather result from including Jizan in the zone of generally high seismicity in North Yemen. Whether it is appropriate to include Jizan in this seismic source zone cannot be confidently assessed until the seismotectonics of the southwest A.rabian Peninsula are better understood.

Figures 18 and 19 show probabilistic ground motions using the high-Q Nuttli and Herrmann (1984) relations. Regardless of what the actual ground- motion attenuation in western Saudi Arabia is (which could only be resolved through additional work beyond the scope of this report), our extreme treatment of the Nuttli and Herrmann (1984) ground-motion relations ensures conservative regional ground-motion estimates for the seismic source zones and the earthquake recurrence model. Table 2 compares values at Haql, Yanbu, Jiddah, and Jizan for the preferred and upper-bound models. The differences between the preferred and upper-bound values of ground motion at any given location are large- the upper-bound estimates being from 40-50 percent larger at Haql to 150 percent larger at Yanbu. The larger differences at lower ground motions are attributable to the slower decrease of ground motion with distance in the Nuttli and Herrmann (1984) attenuation relations as compared to K.W. Campbell's (written commun., 1984) relations. Although the differences in ground motion between the preferred and upper-bound models are large, the regional ground-motion values themselves are, in general, moderate to low as a result of the low rates of seismic activity in the Arabia shield area or, as along the coast, large distances from the modeled fault sources in the Red Sea rift.

Research has shown that statistical variability in ground-motion attenuation relations is a dominant source of uncertainty in estimated ground-motion values (McGuire and Shedlock, 1981; Bender, 1984a). The standard deviation $(\sigma)$ in $\log _{e}$ acceleration appears to lie within a range of $0.35 \leq \sigma \leq 0.65$ and is generally assumed to hold for all magnitudes and distances of the 


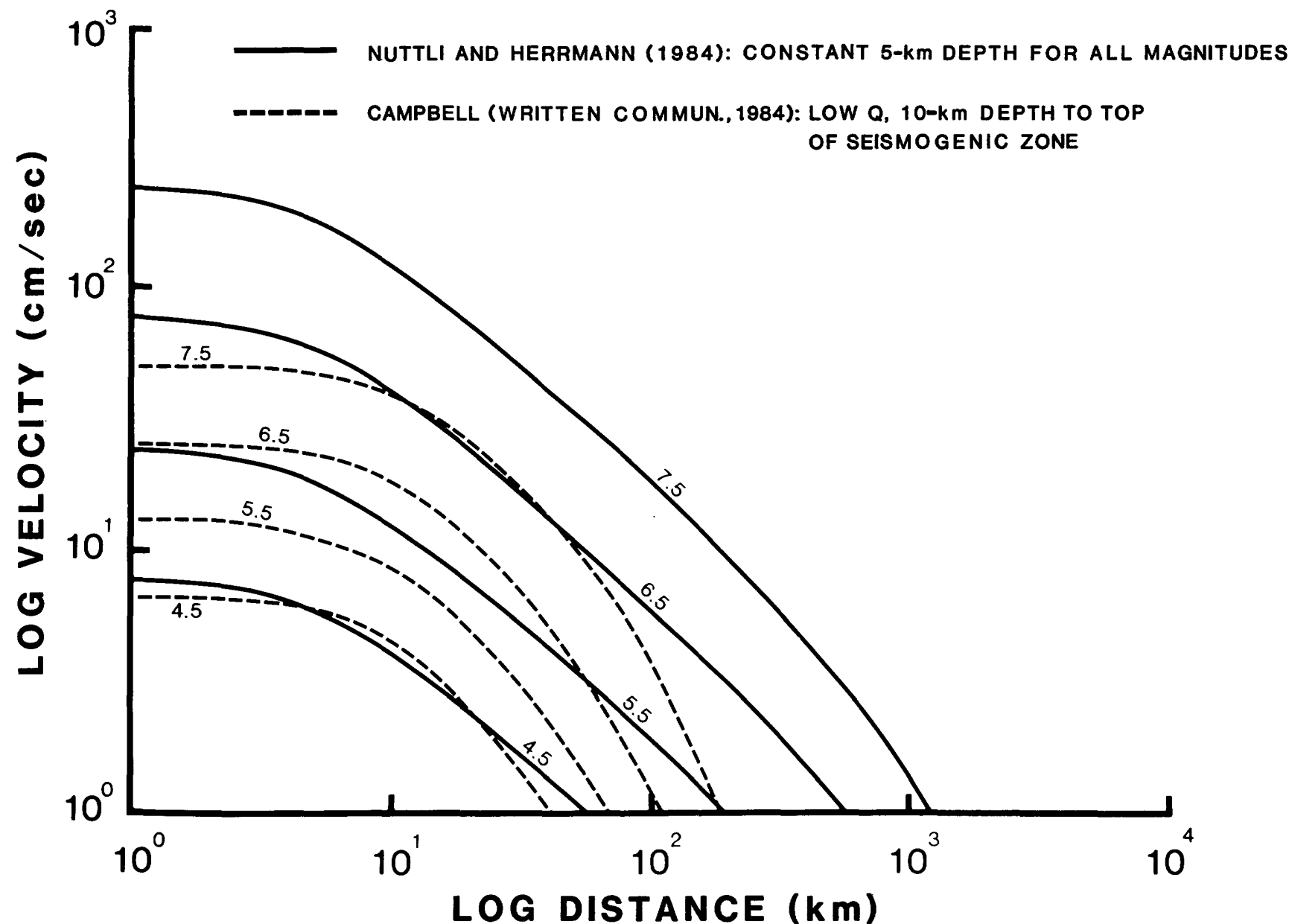

Figure 13. Velocity attenuation curves illustrating the high and low extremes of attenuation relations investigated in this study. Magnitudes and distance measures are as in figure 12.

Table 2. Comparison of peak ground-motion values at Haql, Yanbu, Jiddah, and Jizan obtained from the preferred and upper-bound regional hazard models

[Values in parentheses result from assuming a standard deviation of 0.5 in the attenuation relations]

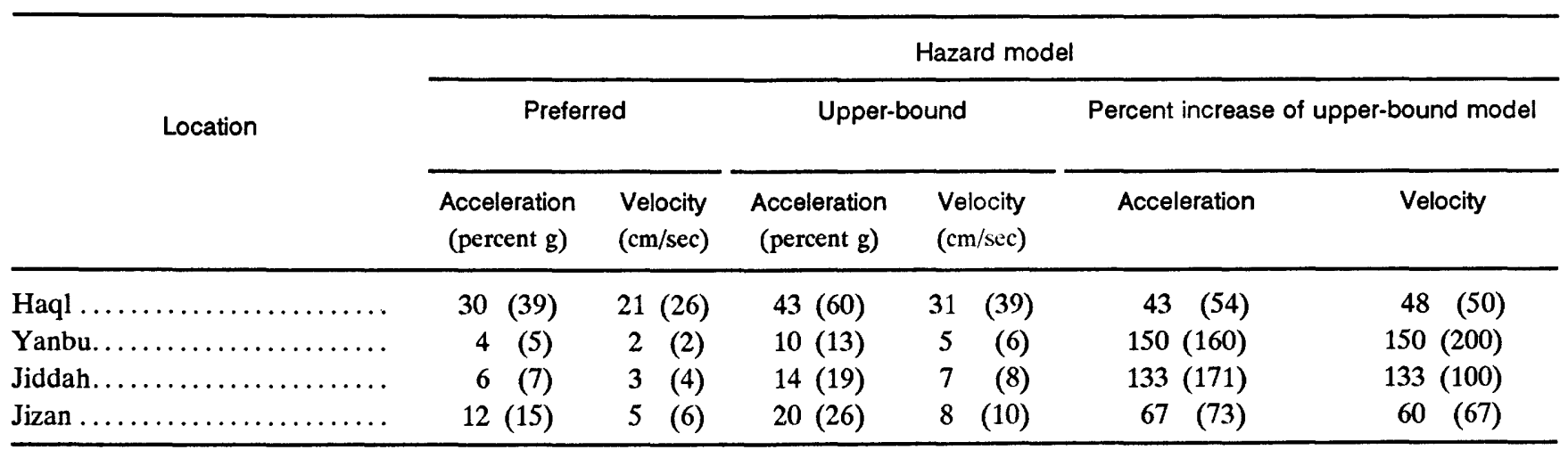




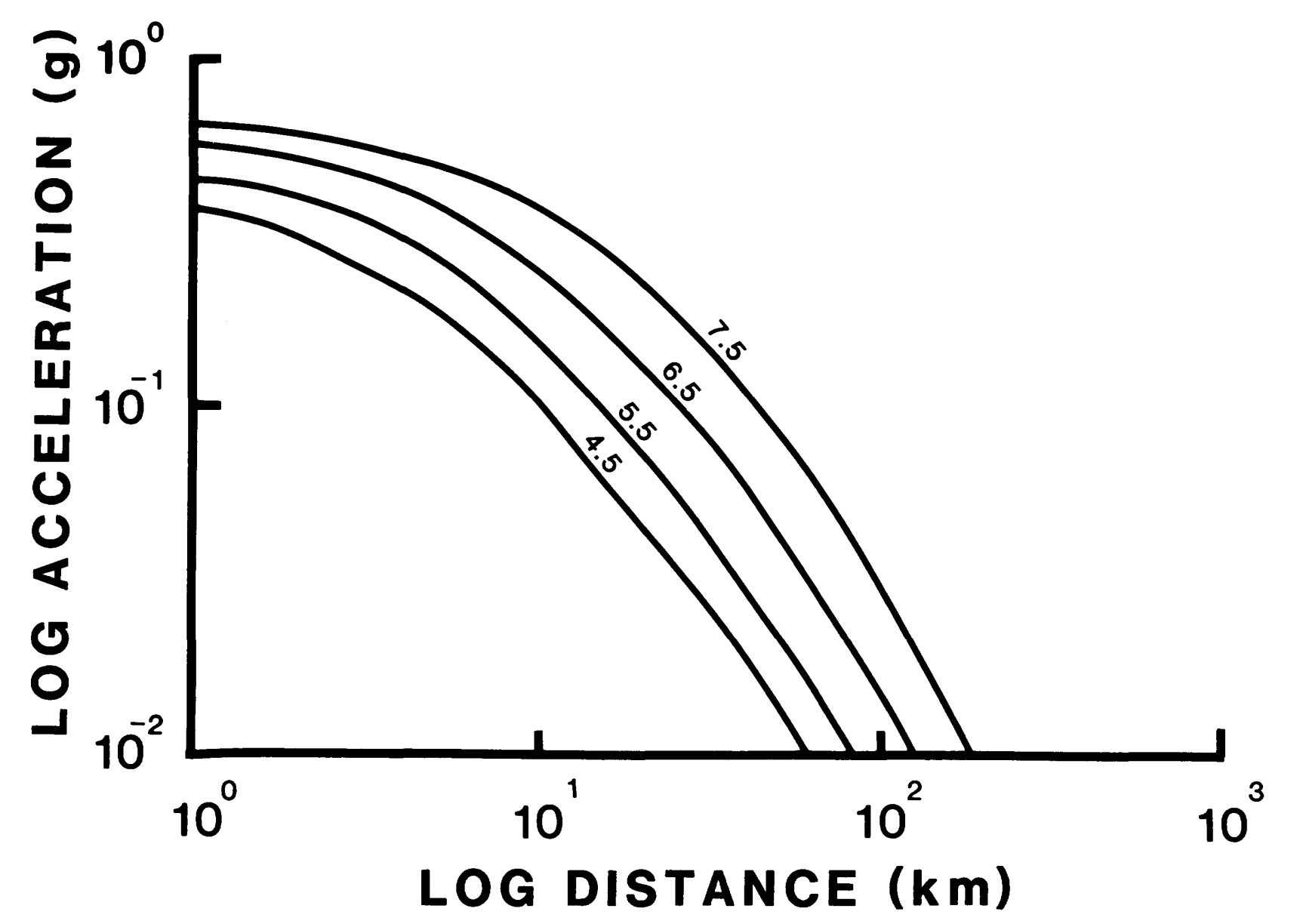

Figure 14. Acceleration attenuation curves for the preferred hazard model: K.W. Campbell (written commun., 1984), low Q, 2-km depth to the top of the seismogenic zone. Magnitudes are $M_{s}$ for $M \geq 6$ and $M_{L}$ for $M<6$. Distance is the shortest distance to the zone of seismogenic rupture.

relation (Bender, 1984a). To illustrate the effect of this uncertainty on the estimated ground motions of this study, figures 20 and 21 compare ground-motion levels along the profiles of figure 9 for the preferred and upper-bound models with and without ground-motion attenuation variability. A standard deviation in $\log _{e}$ (acceleration or velocity) of 0.5 is assumed. Results show that incorporating attenuation variability increases ground motions as much as 60 percent for the highest levels of ground motion in the central Red Sea on the Jiddah profile. Increases in ground-motion values for coastal and interior regions are considerably less.

\section{DISCUSSION AND RECOMMENDATIONS}

The approach to estimating the seismic hazard in the western Arabia Peninsula presented in this report was developed with full consideration of the limited data bases and scientific knowledge regarding the seismotectonics of the region. Indeed, the preferred and the upper-bound hazard maps depict the consequences of models that depend more on scientific judgment than on well-established scientific fact. However, this work has served to highlight those questions that must be addressed to improve future hazard estimates. The hazard maps are submitted as an initial attempt to define the seismic hazard as reasonably as possible using existing data and information. However, an equally important aspect of this study is to identify areas of investigation of a somewhat broader scope that would serve to refine the overall understanding of the seismic hazard problem in western Saudi Arabia. In addition to outstanding questions discussed in the preceding sections of this report, three fruitful areas of further study can be identified: (1) historical and contemporary earthquake studies, (2) studies in contemporary tectonics and paleoseismic field investigations, and (3) investigations into secondary ground-failure hazards.

Refinement of the existing historical-earthquake data base is likely to result from searches of primary Arabic sources. The search performed for this study was 


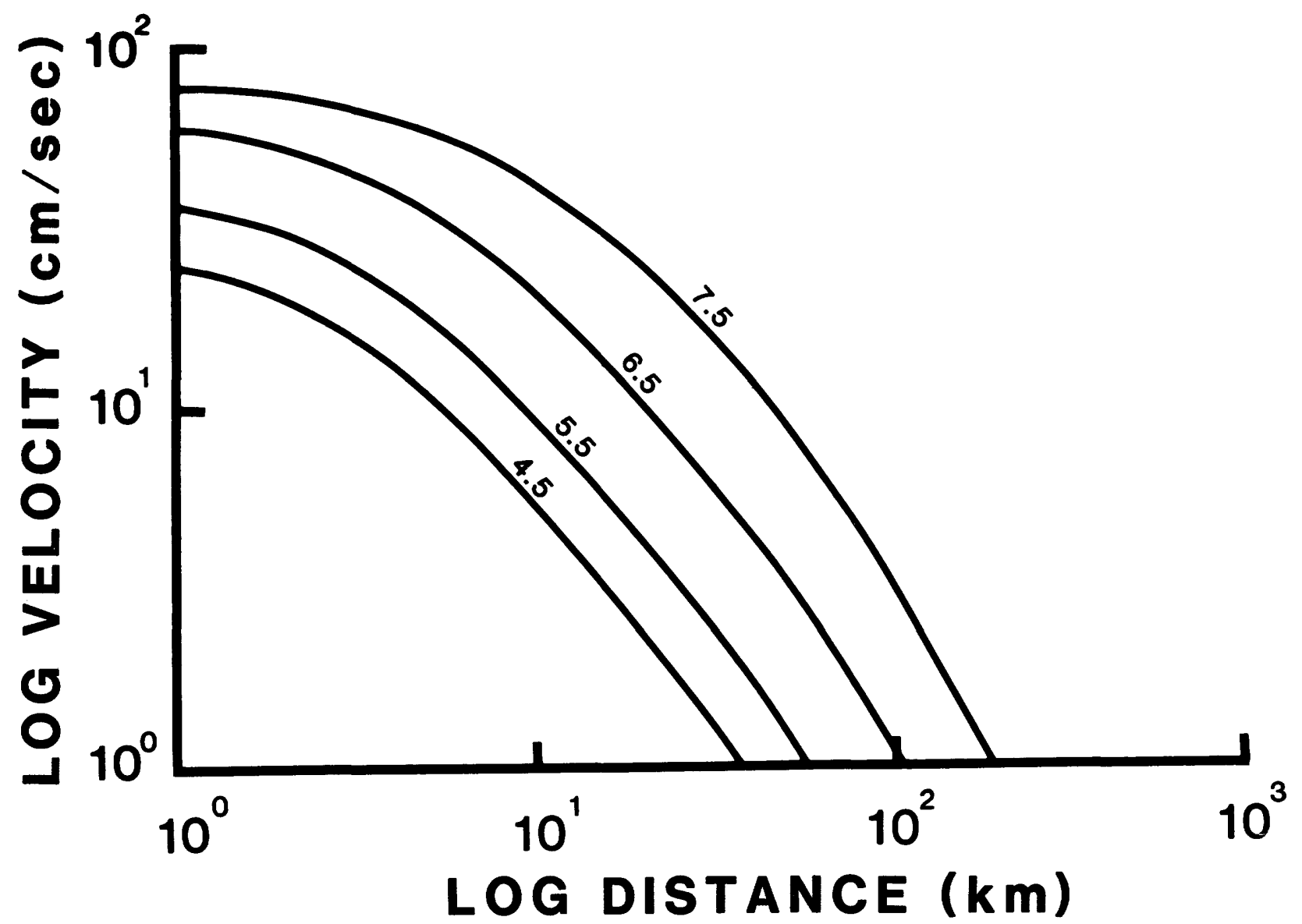

Figure 15. Velocity attenuation curves for the preferred hazard model: K.W. Campbell (written commun., 1984), low $\mathrm{Q}, 2-\mathrm{km}$ depth to the top of the seismogenic zone. Magnitude and distance measures are as in figure 14 .

restricted to the English literature which, for noninstrumental earthquakes of record in the region, is composed of secondary sources. Thorough searches of primary sources have considerably improved historicalearthquake catalogs for areas of the Western United States (Oaks and Algermissen, 1984), in one case producing 50 percent more historical earthquakes than documented in existing catalogs of the southern Basin and Range region (Dubois and others, 1982). In the Eastern United States, a region of relatively low seismic activity, it was the documented occurrence of large historical earthquakes in 1811-1812 (New Madrid, Mo.) and 1886 (Charleston, S.C.) that indicated a seismic hazard problem for this region thus providing impetus for scientific study. A correlative situation in western Saudi Arabia appears in the identification of strong earthquake shaking in the towns of Khaybar and Tayma in the year 1068 (estimated MMI = IX, Poirier and Taher, 1980). In terms of contemporary seismicity, the northwest Arabia peninsula appears virtually aseismic due in large part, perhaps, to a lack of local seismic monitoring. The historical accounts of strong shaking at Khaybar and Tayma are the first indications that a potentially serious seismic hazard may exist in the area. Geologic field investigations of the reported ground disruptions between Khaybar and Tayma could serve to confirm the historical reports and, if substantiated, could perhaps provide a preliminary epicentral area for the event. Geophysical studies and detailed microseismic monitoring could then provide detailed velocity structure and subsurface structure of the area along with accurate microseismic locations. The physical dimensions and geometry of the seismic source could thus be estimated and the potential local seismic hazard evaluated. This simplified investigation scenario follows the form of highly successful earthquake investigations in the Central and Eastern United States (McKeown and Pakiser, 1982; Bollinger and Wheeler, 1982).

Sufficient circumstantial evidence associating seismicity with the Ad Damm fault exists to warrant further earthquake-specific investigations for this fault. If this fault is found to be seismically active, it could very well dominate the earthquake ground-motion hazard at Taif and Mecca because of its close proximity to both of these locations. Ground-motion hazard at Jiddah would result from both the generally far field ground motions 


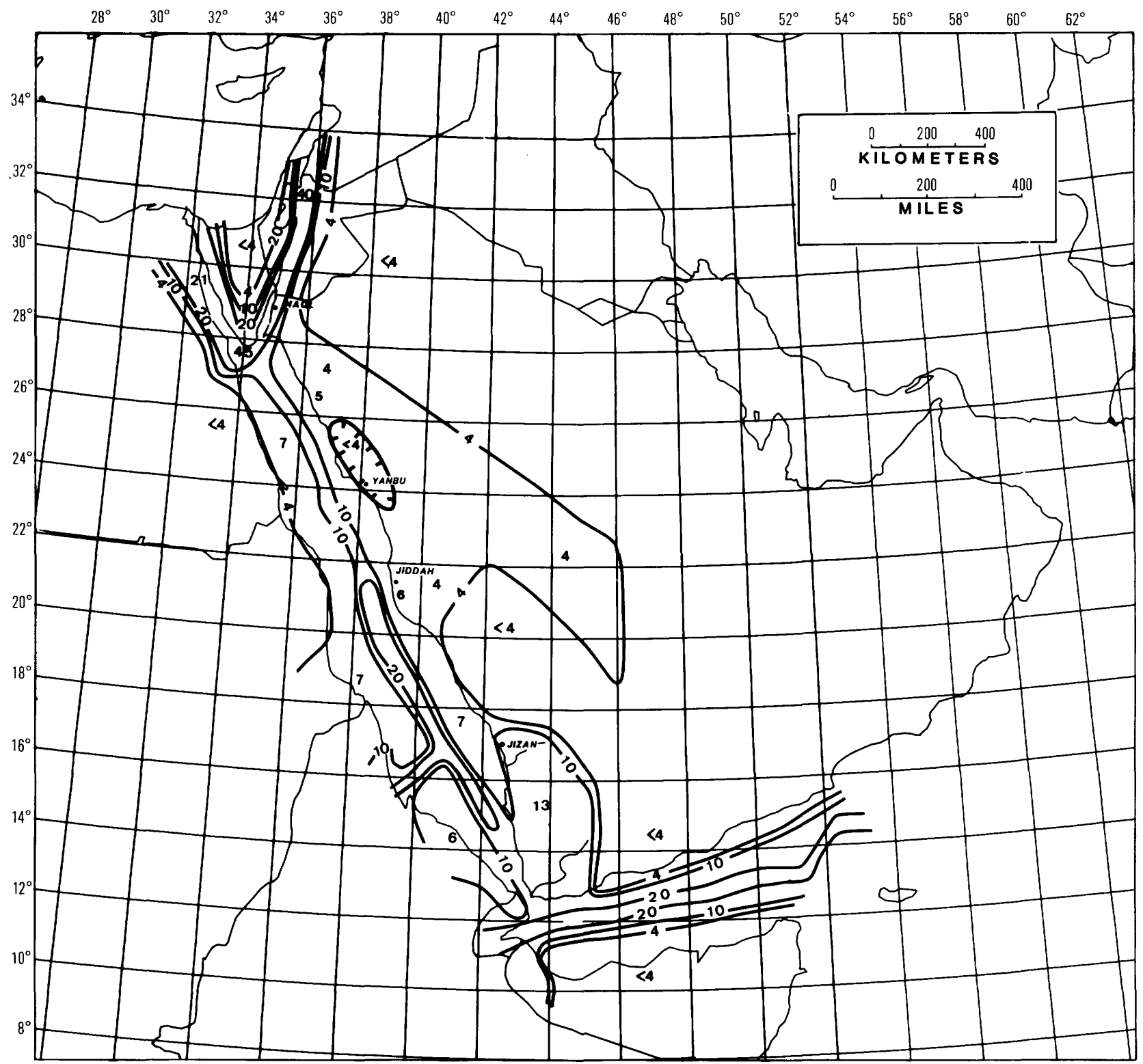

Figure 16. Peak horizontal acceleration with a 90 percent probability of not being exceeded in $100 \mathrm{yr}$, given by the preferred hazard model. Contours are in percent gravity.

produced by the recurrence of earthquakes on the Ad Damm fault and those produced by earthquake sources of the central Red Sea Rift. At this point, all that can be confidently stated is that if the Ad Damm fault is seismically active, it would be an important element to include in future hazard assessments of coastal Saudi Arabia.

Although the presently known earthquake history of western Saudi Arabia resembles that of the Eastern United States, in that the rate of significant earthquake occurrences is apparently low, the recency of tectonic deformation of western Saudi Arabia corresponds to that of the Western United States. That is, Tertiary-
Quaternary tectonics dominate the regional geologic structure of both areas. Because geomorphic/geologic studies of faults and fault scarps have found widespread success in identifying active faults in the Western United States tectonic setting, there is reason to believe that such investigations would similarly find success in western Saudi Arabia. Methods of investigation may not be directly transferable because of different regional climatic histories. Nevertheless, studies of landform degradation and climatic history could lead to paleoseismic, fault-scarp investigation methods specific to the regions conterminous to the Red Sea. Relative- and absolute-age data necessary for distinguishing ages of 


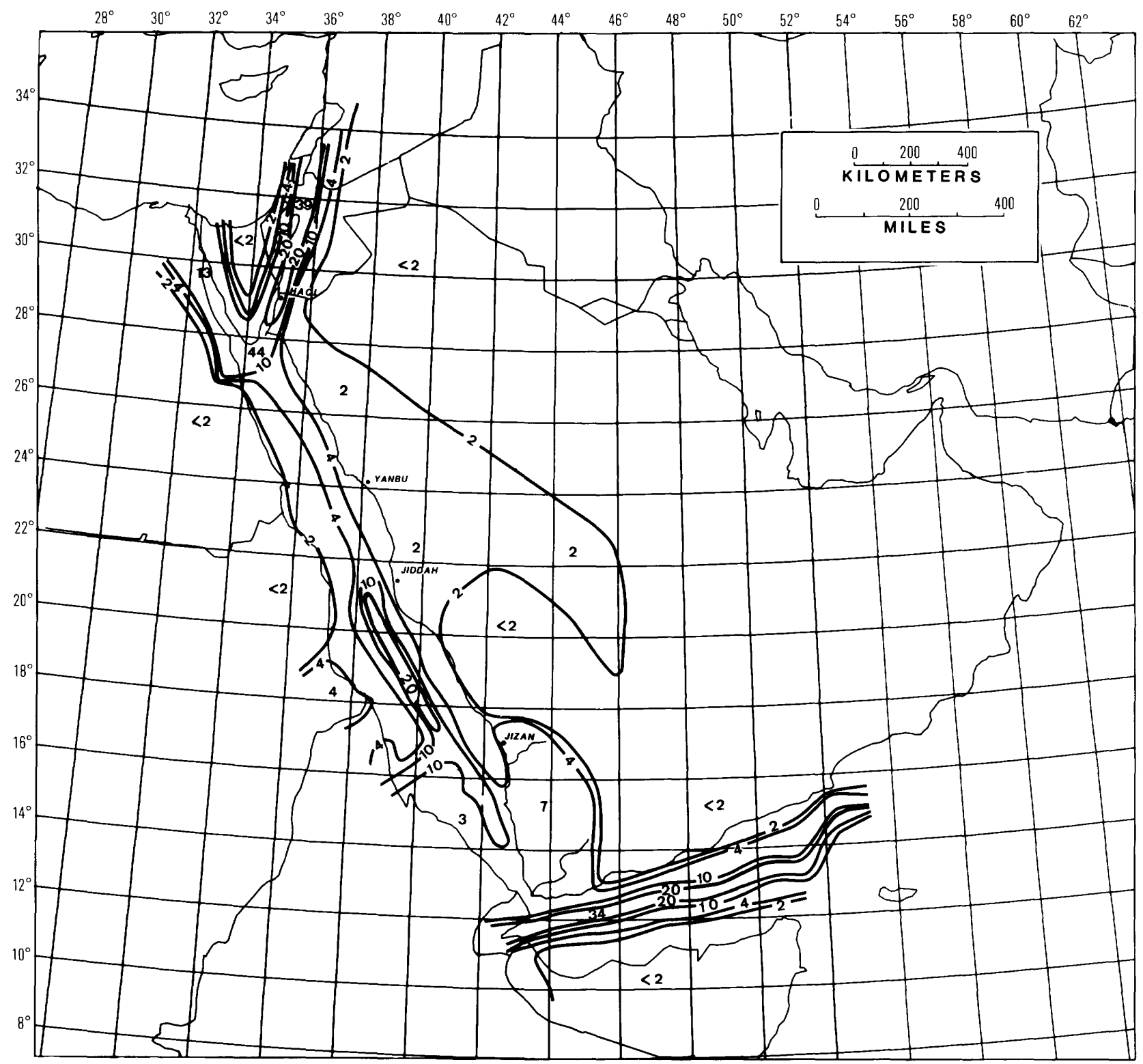

Figure 17. Peak horizontal velocity with a 90 percent probability of not being exceeded in $100 \mathrm{yr}$, given by the preferred hazard model. Contours are in centimeters per second.

faulting are already identifiable for the central and northern coastal regions in the form of raised terraces and coral reefs and interstratified Quaternary basalts (Whitney, 1982). In one case, offset of a raised coral reef located about $45 \mathrm{~km}$ south of Jiddah has been suggested as due to late Pleistocene-Holocene age fault displacement (Pallister, 1982). However, previous fault studies have been only incidental to the primary goal of basic geologic mapping. Standard geologic mapping in the Western United States has proved to be far too insensitive to Quaternary tectonics and faulting to be useful in addressing geologically recent fault movements.
Geologic maps are generally compiled without the required detail and without the proper emphasis on recent tectonics that is needed for careful evaluation of young fault movement. It is important in seismic fault studies of coastal Saudi Arabia to distinguish tectonic, paleoseismic fault rupture from faulting due to salt diapirism, flowage, and solution. Tectonic faults extend to considerable crustal depths and are capable of storing sufficient stress to rupture in significant earthquakes. In contrast, diapiric and solutional faulting is restricted to the stratigraphic section and is generally not associated with earthquakes that produce damaging ground 


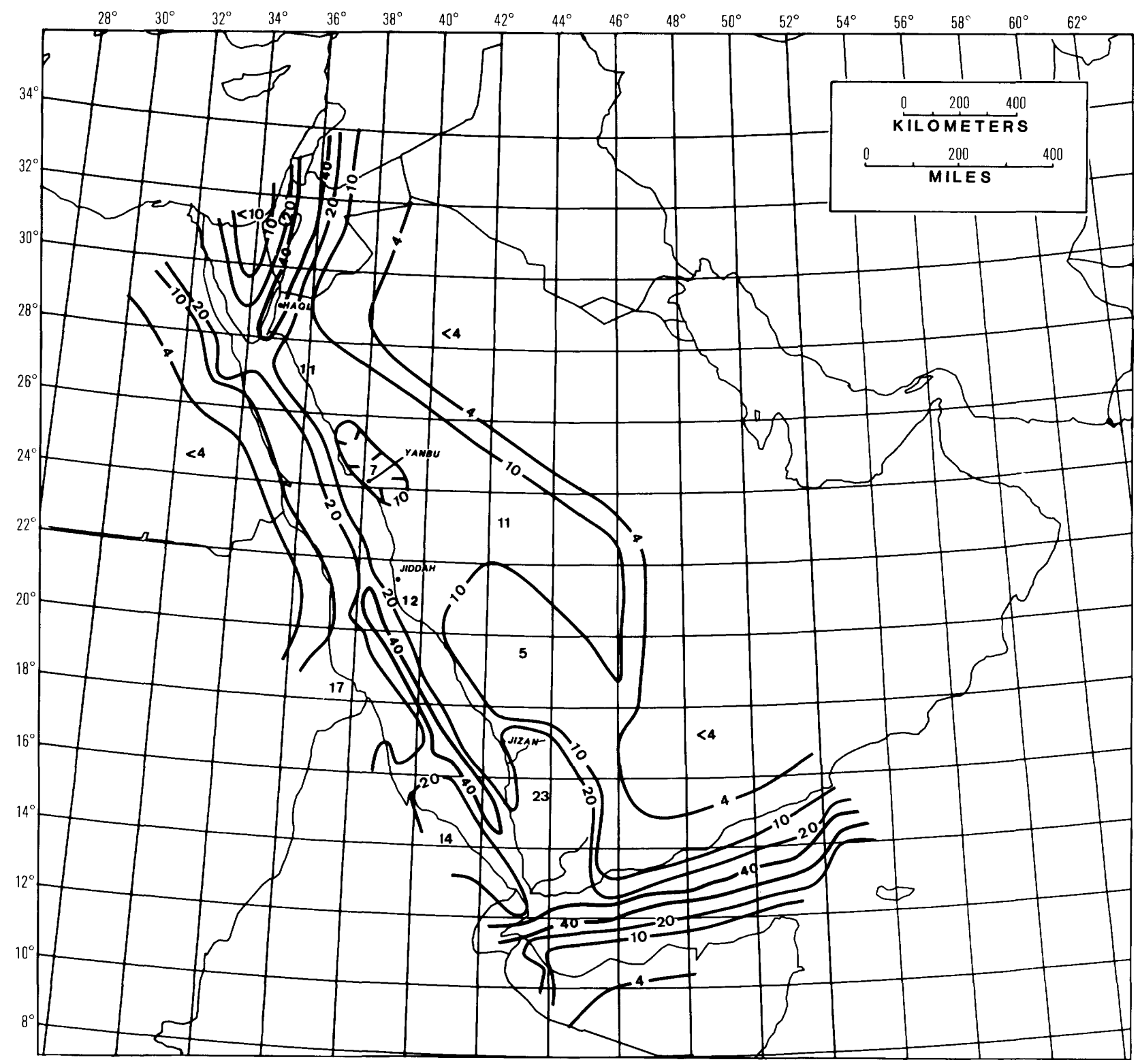

Figure 18. Peak horizontal acceleration with a 90 percent probability of not being exceeded in 100 yr, given by the upper-bound hazard model. Contours are in percent gravity.

motions. Nonetheless, such faulting can result in surface displacement and thus pose a ground-displacement hazard to structures located on or near such faults.

The recommendation for site-specific investigation may appear incongruous with the regional approach of this study. However, it is well known that hazard estimates can change dramatically for specific areas when causal seismogenic faults are identified and earthquake occurrence frequencies and maximum magnitudes are determined specifically for such faults. The consequence is that the hazard can be tied to specific faults, or classes of faults, rather than averaged over broad areas, thus resulting in a more accurate portrayal of a more local seismic hazard.

Secondary ground-failure hazards resulting from earthquakes, such as surface rupture, liquefaction, and landsliding, have not been topics of study in the current analysis. However, a thorough understanding of the earthquake hazard would include a knowledge of those areas susceptible to induced ground failure. Sediments most susceptible to liquefaction are Holocene unconsolidated, cohesionless sands of delta, river-channel, floodplain or eolian deposits, and uncompacted artificial fill, all located in areas having high water tables (Youd and 


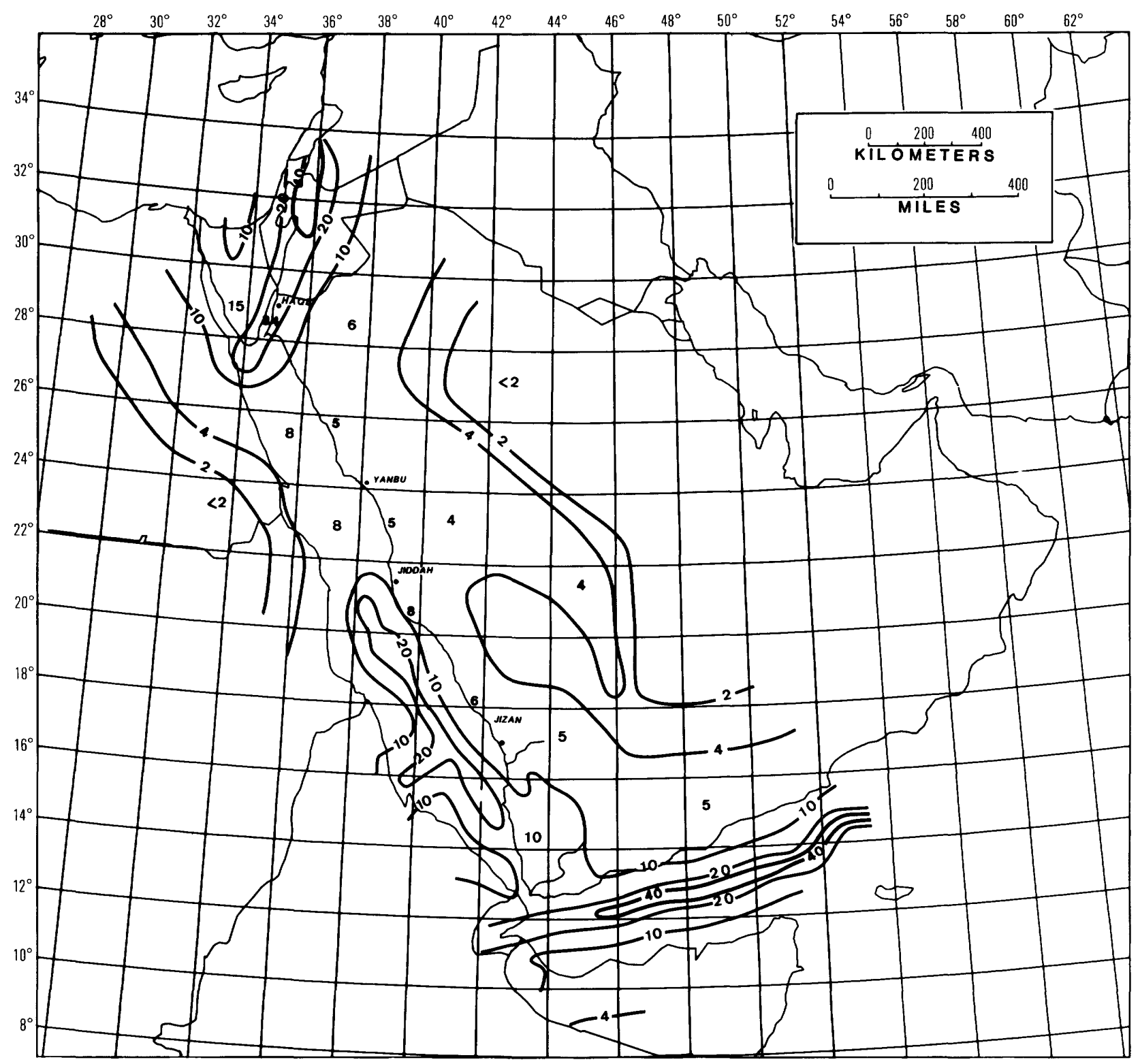

Figure 19. Peak horizontal velocity with a 90 percent probability of not being exceeded in $100 \mathrm{yr}$, given by the upper-bound hazard model. Contours are in centimeters per second.

Perkins, 1978; Youd, 1984). Such conditions may exist at a number of locations along the Red Sea coastal plain. For example, ground-water levels near the wadi systems in the Jizan coastal plain are generally $10 \mathrm{~m}$ or shallower, with saturated alluvium of fluvial and eolian origin extending to depths greater than $100 \mathrm{~m}$ (Müller and others, 1984). In Jiddah, a high water table and development on unengineered fill and reclaimed land pose a potentially serious ground-failure hazard in the event of strong ground shaking.

Near-future progress towards a more complete understanding of the seismic hazard in the western
Arabia peninsula is dependent upon a broad scope of interrelated geologic, seismologic, and geophysical investigations directed at specific "targets of opportunity." Historically reported ground disruptions associated with strong earthquake shaking, such as those reported at Tayma and Khaybar, provide such a target for scientific validation of the historical reports and scientific insights into possible earthquake sources of the region. With the experience and results of such an investigation, future studies could be structured in other areas of the western peninsula in full consideration of scientific methods of investigation that are likely to be applied successfully in the region. 

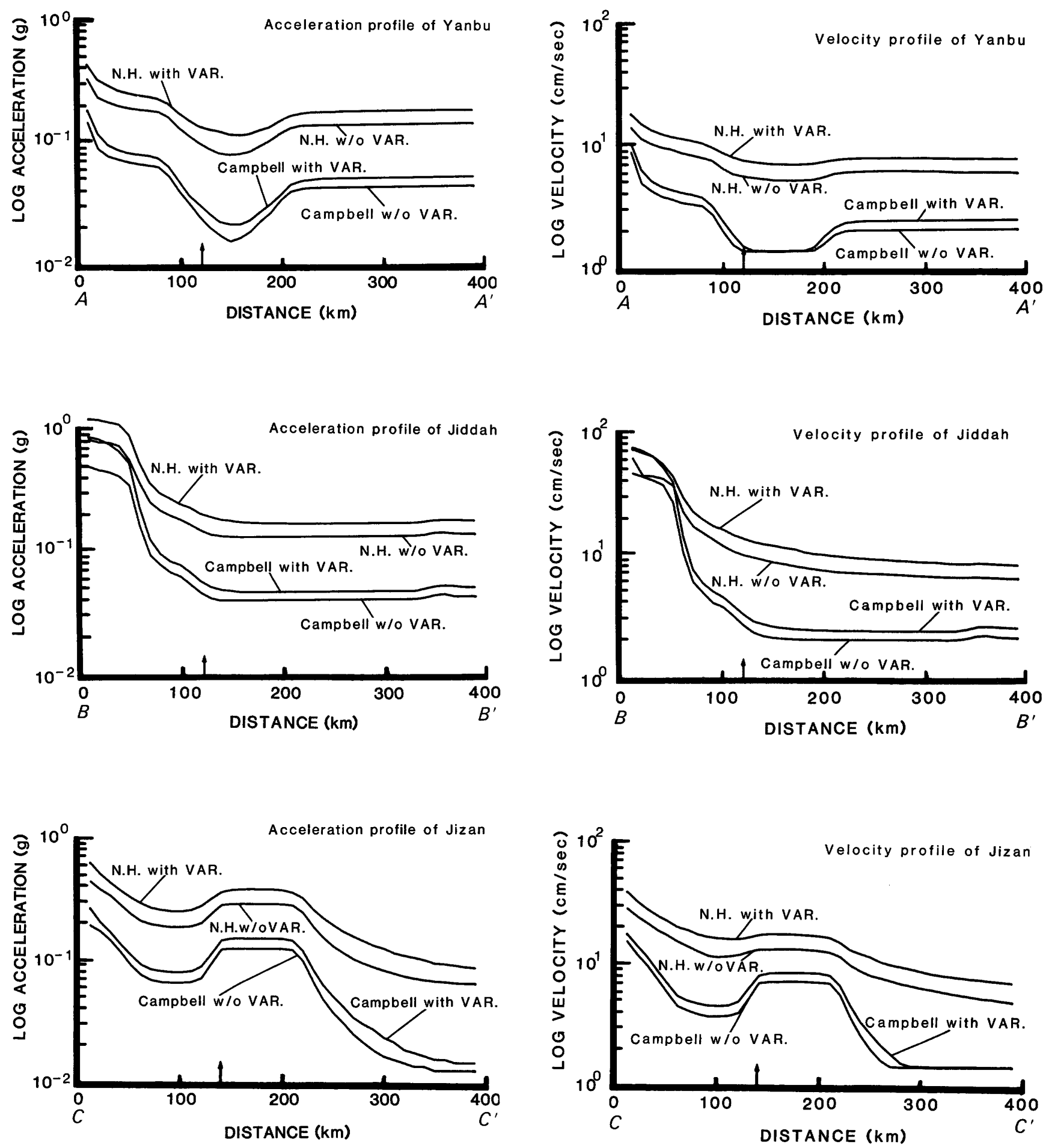

Figure 20. Profiles of peak horizontal acceleration along transects shown in figure 9 showing K.W. Campbell's (written commun., 1984) attenuation model (LQ2 in figure 10) and Nuttli and Herrmann's (N.H.) (1984) attenuation model (MNH in figure 10) with and without attenuation variability. Attenuation variability modeled as standard deviation 0.5 in log. acceleration.

Figure 21. Profiles of peak horizontal velocity along transects of figure 9. Labels are as in figure 20. Attenuation variability modeled as standard deviation 0.5 in log. velocity. 
ACKNOWLEDGMENTS

Funding for this work was provided by the Ministry of Petroleum and Mineral Resources, Deputy Ministry for Mineral Resources, Kingdom of Saudi Arabia. We thank J.W. Dewey and K.W. Campbell for their reviews and helpful suggestions.

\section{REFERENCES CITED}

Abdallah, A., Courtillott, V., Kasser, M., LePain, A., Lépine, J., Robineau, B., Ruegg, J., Tapponnier, P., and Tarantota, A., 1979, Relevence of Afar seismicity and volcanism to the mechanics of accreting plate boundaries: Nature, $v$. 282 , p. $17-23$.

Algermissen, S.T., and Perkins, D.M., 1976, A probabilistic estimate of maximum acceleration in rock in the contiguous United States: U.S. Geological Survey OpenFile Report 76-416, 45 p.

Algermissen, S.T., Perkins, D.M., Thenhaus, P.C., Hanson, S.L., and Bender, B.L., 1982, Probabilistic estimates of maximum acceleration and velocity in the contiguous United States: U.S. Geological Survey Open-File Report 82-1033, 99 p.

Ambraseys, N.N., and Melville, C.P., 1983, Seismicity of Yemen: Nature, v. 3, no. 591, p. 321-323.

Arya, A.S., Srivastava, L.S., and Gupta, S.P., 1985, Survey of damages during the Dhamar earthquake of 13 December 1982 in the Yemen Arab Republic: Seismological Society of America Bulletin, v. 75, p. 597-610.

Barberi, F., Ferrara, G., Santacloce, R., and Varet, J., 1975, Structural evolution of the Afar triple junction, in Piler, A., and Rösler, A., eds., Afar depression of Ethiopia: Inter-Union Commission on Geodynamics, Scientific Report 14, Verlagsrbuchhanolung, Stuttgart, p. 38-54.

Barberi, F., and Varet, J., 1977, Volcanism of Afar-Smallscale plate tectonics implications: Geological Society of America Bulletin, v. 88, no. 9, p. 1251-1266.

Bender, Bernice, 1982, Sensitivity analysis for seismic risk using a fault rupture model: U.S. Geological Survey Open-File Report 82-294, 75 p.

1983, Maximum likelihood estimation of b-values for magnitude grouped data: Seismological Society of America Bulletin, v. 73, p. 831-851.

1984a, Incorporating acceleration variability into seismic hazard analysis: Seismological Society of America Bulletin, v. 74, p. 1451-1462.

1984b, Seismic hazard estimation using a finite fault rupture model: Seismological Society of America Bulletin, v. 74, p. 1899-1923.

Ben-Menahem, Ari, 1981, Variation of slip and creep along the Levant Rift over the past 4500 years, in Freund, R., ed., The Dead Sea Rift-International Symposium on the Dead Sea Rift, Jerusalem, Sept. 10-20, 1979: Tectonophysics, v. 80, no. 1-4 (special issue), p. 183-197.

Ben-Menahem, Ari, and Aboodi, Ezra, 1971, Tectonic patterns in the northern Red Sea region: Journal of Geophysical Research, v. 76 , no. 11 , p. 2674-2689.
1981, Micro- and macroseismicity of the Dead Sea Rift and off-coast eastern Mediterranean, in Freund, R., ed., The Dead Sea Rift-International Symposium on the Dead Sea Rift, Jerusalem, Sept. 10-20, 1979: Tectonophysics, v. 80 , no. 1-4 (special issue), p. 199-233.

Blank, H.R., Jr., 1977, Aeromagnetic and geologic study of tertiary dikes and related structures on the Arabian margin of the Red Sea, in Red Sea research 1970-1975: Saudi Arabian Directorate General of Mineral Resources Bulletin 22, p. G1-G18.

Bohannon, R.G., 1986, Tectonic configuration of the Western Arabian Continental Margin, Southern Red Sea: Tectonics, v. 5, p. 477-499.

Bollinger, G.A., and Wheeler, R.L., 1982, The Giles County, Virginia, seismogenic zone-Seismological results and geological interpretations: U.S. Geological Survey OpenFile Report 82-585, 136 p.

Brown, G.F., 1972, Tectonic map of the Arabian Peninsula: Saudi Arabian Directorate General of Mineral Resources Arabian Peninsula Map AP-2, scale $1: 4,000,000$.

Burr, N.C., and Solomon, S.C., 1978, The relationship of source parameters of oceanic transform earthquakes to plate velocity and transform length: Journal of Geophysical Research, v. 83, p. 1193-1205.

Campbell, K. W., 1981, Near-source attenuation of peak horizontal acceleration: Seismological Society of America Bulletin, v. 71, p. 2039-2070.

1982, Near-source scaling characteristics of peak horizontal acceleration for moderate-to-large earthquakes, in Boatwright, John, ed. and organizer, Proceedings of Conference XVI, The dynamic characteristics of faulting as inferred from recordings of strong ground motion: U.S. Geological Survey Open-File Report 82-591, v. 1, p. 120-184.

1983, The effects of site characteristics on near-source recordings of strong ground motion, in Hays, W.W., ed., Proceedings of Conference XXII, A workshop on site specific effects of soil and rock on ground motion and the implications for earthquake-resistant design: U.S. Geological Survey Open-File Report 83-845, p. 280-309.

1984, Near-source attenuation of strong ground motion for moderate to large earthquakes-An update and suggested application to the Wasatch fault zone of northcentral Utah, in Hays, W.W., and Gori, P.L., eds., Proceedings of Conference XXVI, A workshop on evaluation of regional and urban earthquake hazards and risk in Utah: U.S. Geological Survey Open-File Report 84-763, p. 438-499.

1985, Strong motion attenuation relations - A ten year perspective: Earthquake Spectra, v. 1, p. 759-804.

1987, Predicting strong ground motion in Utah, in Gori, P.L., and Hays, W.W., eds., Assessment of regional earthquake hazard and risk along the Wasatch front, Utah: U.S. Geological Survey Open-File Report 87-585, p. L1-L90. 
Cochran, J.R., 1981, The Gulf of Aden-Structure and evolution of a young ocean basin and continental margin: Journal of Geophysical Research, v. 86, no. B1, p. 263-287.

1982, The magnetic quiet zone in the eastern Gulf of Aden-Implications for the early development of the continental margin: Geophysical Journal of the Royal Astronomical Society, v. 68, no. 2, p. 171-201.

1983, A model for the development of the Red Sea: American Association of Petroleum Geologists Bulletin, v. 67 , no. $1 .$, p. $41-69$.

Coleman, R.G., 1973, Geologic map of the Red Sea, in Red Sea Research 1970-1975: Saudi Arabian Directorate General of Mineral Resources Bulletin 22, pl. 1.

1977, Geologic background of the Red Sea, in Red Sea Research, 1970-1975: Saudi Arabian Directorate General of Mineral Resources Bulletin 22, p. C1-C9.

Cornell, C.A., 1968, Engineering seismic risk analysis: Seismological Society of America Bulletin, v. 58, p. 1583-1606.

Crowell, J.C., 1974, Origin of late Cenozoic basins in southern California, in Dickinson, W.R., ed., Tectonics and sedimentation: Society of Economic Paleontologists and Mineralogists Special Paper 22, p. 190-204.

Diment, W.H., Urban, T.C., Sass, J.H., Marshall, B.U., Munroe, R.J., and Lachenbruch, A.H., 1975, Temperatures and heat contents based on conductive transport of heat, in White, O.E., and Williams, D.L., eds., Assessment of geothermal resources of the United States-1975: U.S. Geological Survey Circular 726, p. 84-103.

Drake, C.L., and Girdler, R.W., 1964, A geophysical study of the Red Sea: Geophysical Journal, v. 8, p. 473-495.

Dubois, S.M., Sbar, M.L., and Nowak, T.A., 1982, Historical seismicity in Arizona: U.S. Nuclear Regulatory Commission Report NUREG/CR-2577, 199 p.

Eyal, M., Eyal, Y., Bartov, Y., and Steinitz, G., 1981, The tectonic development of the western margin of the Gulf of Elat (Aqaba) Rift, in Freund, R., ed., The Dead Sea Rift-International Symposium on the Dead Sea Rift, Jerusalem, Sept. 10-20, 1979: Tectonophysics, v. 80, no. 1-4 (special issue), p. 39-66.

Fairhead, J.D., and Girdler, R.W., 1970, The seismicity of the Red Sea, Gulf of Aden and Afar triangle: Philosophical Transactions of the Royal Society of London, v. 267, p. 49-74.

Forsyth, D., and Rowlett, H., 1979, Microearthquakes and recent faulting at the intersection of the Vema fracture zone and the mid-Atlantic ridge [abs.]: EOS, Transactions of the American Geophysical Union, v. 60, p. 376.

Francis, T.J.G., Porter, I.T., and Lilwall, R.C., 1978, Microearthquakes near the eastern end of St. Paul's fracture zone: Geophysical Journal of the Royal Astronomical Society, v. 53, p. 201-217. Frazier, S.B., 1970, Adjacent structures of Ethiopia-That portion of the Red Sea coast including Dahlah Kebir Island and the Gulf of Zula: Philosophical Transactions of the Royal Society of London, v. 267, p. 131-141.
Garfunkel, Zvi, 1981, Internal structure of the Dead Sea leaky transform (rift) in relation to plate kinematics, in Freund, $R$., ed., The Dead Sea Rift-International Symposium on the Dead Sea Rift, Jerusalem, Sept. 10-20, 1979: Tectonophysics, v. 80 , no. 1-4 (special issue), p. 81-108.

Garfunkel, Z., and Bartov, Y., 1977, The tectonics of the Suez rift: Israel Geological Survey Bulletin 71, 44 p.

Garfunkel, Z., Zak, I., and Freund, R., 1981, Active faulting in the Dead Sea rift, in Freund, R., ed., The Dead Sea Rift-International Symposium on the Dead Sea Rift, Jerusalem, Sept. 10-20, 1979: Tectonophysics, v. 80, no. 1-4 (special issue), p. 1-26.

Gettings, M.E., 1977, Delineation of the continental margin in the southern Red Sea region from new gravity evidence, in Red Sea research 1970-1975: Saudi Arabian Directorate General of Mineral Resources Bulletin 22, p. K1-K11.

Gettings, M.E., Blank, H.R., Mooney, W.D., and Healy, J.H., 1983, Crustal structure of southwestern Saudi Arabia: Saudi Arabian Deputy Ministry for Mineral Resources Open-File Report USGS-OF-03-59, 51 p.

Geukens, F., 1966, Geology of the Arabian Peninsula-Yemen [translated from French by S.D. Bowers]: U.S. Geological Survey Professional Paper 560-B, 23 p.

Girdler, R.W., 1970, An aeromagnetic survey of the junction of the Red Sea, Gulf of Aden and Ethiopean rifts-A preliminary report: Philosophical Transactions of the Royal Society of London, v. 267, p. 359-368.

Girdler, R.W., and Styles, P., 1974, Two stage Red Sea floor spreading: Nature, v. 247, p. 7-11.

Gouin, P., 1970, Seismic and gravity data from Afar in relation to surrounding areas: Philosophical Transactions of the Royal Society of London, v. 267, p. 339-358.

1979, Earthquake history of Ethiopia and the horn of Africa: Ottawa, Canada, International Development Research Center, report IDRC-118e, 259 p.

Gouin, P., and Mohr, P.A., 1964, Gravity traverses in Ethiopia: Bulletin of the Geophysical Observatory, v. 3, no. 2, p. 185-239.

Greenwood, W.R., Anderson, R.E., Fleck, R.J., and Roberts, R.J., 1980, Precambrian geologic history and plate tectonic evolution of the Arabian shield: Saudi Arabian Directorate General of Mineral Resources Bulletin 24, $35 \mathrm{p}$.

Gutenberg, B., and Richter, C. F., 1954, Seismicity of the earth [2d ed.]: Princeton, N.J., Princeton University Press, $310 \mathrm{p}$.

Hall, S.A., 1980, A total intensity magnetic anomaly map of the Red Sea and its interpretation: U.S. Geological Survey Open-File Report 80-131, 271 p.

Hall, S.A., Andreasen, G.E., and Girdler, R.W., 1977, Totalintensity magnetic anomaly map of the Red Sea and adjacent coastal areas-A description and preliminary interpretation, in Red Sea research 1970-1975: Saudi Arabian Directorate General of Mineral Resources Bulletin 22, p. F1-F15.

Hamilton, R.M., 1981, Geologic origin of eastern U.S. seismicity, in Beavers, J.E., ed., Earthquakes and earthquake engineering-The Eastern United States, v. 1: Ann Arbor, Mich., Ann Arbor Science Inc., p. 3-24. 
Harpum, J.R., 1970, Summary of the geology of Tanzania, [chap.] V; Structure and geotectonics of the Precambrian: Dodoma, Tanzania, Mineral Resources Division, $58 \mathrm{p}$.

Heirtzler, J.R., Dickson, G.O., Herron, E.M., Pitman, W.C., III, and Le Pichon, X., 1968, Marine magnetic anomalies, geomagnetic reversals, and motions of the ocean floor and continents: Journal of Geophysical Research, v. 73, p. 2119-2136.

Joyner, W.B., and Boore, D.M., 1981, Peak horizontal acceleration and velocity from strong-motion records including records from the 1979 Imperial Valley, California, earthquake: Seismological Society of America Bulletin, v. 71, p. 2011-2038.

Juch, D., 1975, Geology of the southeastern escarpment of Ethiopia between $30^{\circ}$ and $42^{\circ}$ longitude east, in Pilger, A., and Rösler, A., eds., Afar depression of Ethiopia: Inter-Union Commission on Geodynamics, Scientific Report no. 14, Verlagsbuchhandlung, Stuttgart, p. 310-315.

Kronberg, P., Schönfeld, M., Günther, R., and Tsombos, P., 1975, Tectonic relations of the Afar region and adjacent areas, in Pilger, A., and Rösler, A., eds., Afar depression of Ethiopia: Inter-Union Commission on Geodynamics, Scientific report 14, Verlagsbuchhandlung, Stuttgart, p. 19-27, 2 pls., scale 1:1,000,000.

Langer C.J., and Merghelani, H.M., 1983, Aftershocks of the Yemen earthquake of December 13, 1982-A detailed study from locally recorded data [abs.]: Earthquake Notes, v. 54, p. 20.

Laughton, A.S., 1966, The Gulf of Aden: Philosophical Transactions of the Royal Society of London, v. 259, ser. A, p. 150-171.

Laughton, A.S., Whitmarsh, R.B., and Jones, M.T., 1970, The evolution of the Gulf of Aden: Philosophical Transactions of the Royal Society of London, v. 267, p. 227-266.

Le Pichon, X., and Francheteau, J., 1978, A plate-tectonic analysis of the Red Sea-Gulf of Aden area, in Oren, O.H., ed., Structure and tectonics of the eastern Mediterranean: Tectonophysics, v. 46, p. 369-406.

Le Pichon, X., and Sibuet, J.C., 1981, Passive margins-A model of formation: Journal of Geophysical Research, v. 86, p. $3708-3720$.

Mark, R.K., 1977, Application of linear statistical models of earthquake magnitude versus fault length in estimating maximum expectable earthquakes: Geology, v. 5, p. 464-466.

Mark, R.K., and Bonilla, M.G., 1977, Regression analysis of earthquake magnitude and surface fault length using the 1970 data of Bonilla and Buchanan: U.S. Geological Survey Open-File Report 77-614, 9 p.

McConnell, R.B., 1967, The east African rift system: Nature, v. 215 , p. $578-581$.

1972, Geological development of the rift system of eastern Africa: Geological Society of America Bulletin, v. 83 , p. 2549-2572.
McGuire, R.K., and Shedlock, K.M., 1981, Statistical uncertainties in seismic hazard evaluations in the United States: Seismological Society of America Bulletin, v. 71, no. 4 , p. $1287-1308$.

McKenzie, D.P., Davies, D., and Molnar, P., 1970, Plate tectonics of the Red Sea and East Africa: Nature, v. 226, p. 243-248.

McKeown, F.A., and Pakiser, L.C., 1982, Investigations of the New Madrid, Missouri, earthquake region: U.S. Geological Survey Professional Paper 1236, 201 p.

Merghelani, H.M., 1979, Seismicity of the Tihmat-Asir region, Kingdom of Saudi Arabia: U.S. Geological Survey Saudi Arabian Project Report 261, 20 p.

1981, Seismicity of the Yanbu region, Kingdom of Saudi Arabia: U.S. Geological Survey Saudi Arabian Project Report 371, Technical Record 16, 32 p.

Merghelani, H.M., Kinkar, A.R., and As-Sawwaf, M.W., 1981, Seismicity studies in Saudi Arabia-Microearthquakes in the Jiddah area: Saudi Arabian Directorate General of Mineral Resources Open-File Report DGMROF-01-08, 64 p.

Ministry of Defence, Director of Military Survey, United Kingdom, 1980, Political map of the Arabian Peninsula: U.S. Geological Survey and the Arabian American Oil Company, compilers, under sponsorship of the Kingdom of Saudi Arabia, Ministry of Petroleum and Mineral Resources and the U.S. Department of State, scale $1: 2,250,000$.

Mohr, P.A., 1975, Structural setting and evolution of Afar, in Pilger, A., and Rösler, A., eds., Afar depression of Ethiopia: Inter-Union Commission on Geodynamics, Scientific Report 14, Verlagsbuchhandlung, Stuttgart, p. 27-37.

Molnar, P., and Oliver, J., 1969, Lateral variations of attenuation in the upper mantle and discontinuities in the lithosphere: Journal of Geophysical Research, v. 74, p. 2648-2681.

Mooney, W.D., Gettings, M.E., Blank, H.R., and Healy, J.H., 1985, Saudi Arabian seismic deep-refraction profile-A travel time interpretation of deep crustal structure: Tectonophysics, v. 111, p. 173-246.

Morton, W.H., and Black, R., 1975, Crustal attenuation in Afar, in Pilger, A., and Rösler, A., eds., Afar depression of Ethiopia: Inter-Union Commission on Geodynamics, Scientific Report 14, Verlagsbuchhandlung, Stuttgart, p. 55-65.

Müller, E., Fredrich, K., and Klinge, H., 1984, Hydrogeology of the Tihamat Asir, in Jado, A.R., and Zötl, J.G., Quaternary Period in Saudi Arabia, V.Z.: ; New York, Springer-Verlag Publishers, p. 174-194.

Nishenko, S.P., and McCann, W.R., 1981, Seismic potential for the world's major plate boundaries, in Simpson, D.W., and Richards, P.G., eds, Earthquake prediction, an international review, Maurice Ewing series: American Geophysical Union, v. 4, p. 20-28.

Nuttli, O.W., 1983, Average seismic source-parameter relations for mid-plate earthquakes: Seismological Society of America Bulletin, v. 73, p. 519-535. 
Nuttli, O.W., and Herrmann, R.B., 1984, Ground motion of Mississippi Valley earthquakes: Journal of Technical Topics in Civil Engineering, v. 110, p. 54-69.

Oaks, S.D., and Algermissen, S.T., 1984, Investigation of historical seismicity in the Salt Lake City portion of the Wasatch front region of Utah using documentary sources, in Hays, W.W., and Gori, P.L., eds., Proceedings of Conference XXVI, A workshop on evaluation of regional and urban earthquake hazards and risk in Utah: U.S. Geological Survey Open-File Report 84-763, p. 384-390.

Oliver, J., and Isacks, B., 1967, Deep earthquake zones, anomalous structures in the upper mantle, and the lithosphere: Journal of Geophysical Research, v. 72, p. 4259-4275.

Pallister, J.S., 1982, Reconnaissance geologic map of the Shu Ayba quadrangle, sheet 20/39, Kingdom of Saudi Arabia: Saudi Arabian Deputy Ministry for Mineral Resources Open-File Report USGS-OF-02-59, 1 pl.

1984, Explanatory notes to the geologic map of the $\mathrm{Al}$ Lith quadrangle, sheet 20 D, Kingdom of Saudi Arabia: Saudi Arabian Deputy Ministry for Mineral Resources Open-File Report USGS-OF-04-8, 124 p., 1 pl.

Phillips, J.D., and Ross, D.A., 1970, Continuous seismic reflexion profiles in the Red Sea: Philosophical Transactions of the Royal Society of London, v. 267, p. 143-152.

Pilger, A., and Rösler, A., 1975, eds., Afar depression of Ethiopia: Inter-Union Commission on Geodynamics, Scientific Report 14, Verlagsbuchhandlung, Stuttgart, $416 \mathrm{p}$.

Poirier, J.P., and Taher, M.A., 1980, Historical seismicity in the Near and Middle East, North Africa, and Spain from Arabic documents (VIIth-XVIIth century): Seismological Society of America Bulletin, v. 70, no. 6, p. 2185-2201.

Project Rose Scientists, 1981, Microearthquake activity on the Orozco fracture zone-Preliminary results from project Rose: Journal of Geophysical Research, v. 86, p. 3783-3790.

Quennell, A.M., 1956, Tectonics of the Dead Sea rift, in Association of African Geological Surveys Symposium, 20th International Geology Congress, Mexico City, 1956: p. 385-405.

Reches, Ze'ev, and Hoexter, D.F., 1981, Holocene seismic and tectonic activity in the Dead Sea area, in Freund, R., ed., The Dead Sea Rift-International Symposium on the Dead Sea Rift, Jerusalem, Sept. 10-20, 1979: Tectonophysics, v. 80, p. 235-254.

Riad, S., 1977, Shear zones in North Egypt interpreted from gravity data: Geophysics, v. 42, no. 6, p. 1207-1214.

Ross, D.A., and Schlee, J., 1973, Shallow structure and geologic development in the southern Red Sea: Geological Society of America Bulletin, v. 84, p. 3827-3848.

1977, Shallow structures and geologic development of the southern Red Sea, in Red Sea research 1970-1975: Saudi Arabian Directorate General of Mineral Resources Bulletin 22, p. E1-E18.

Rowlett, H., 1981, Seismicity at intersections of spreading centers and transform faults: Journal of Geophysical Research, v. 86, no. B5, p. 3815-3820.
Said, R., 1962, The geology of Egypt: New York, Elsevier, 377 p.

Schmidt, D.L., Hadley, D.G., and Brown, G.F., 1983, Middle Tertiary continental rift and evolution of the Red Sea in southwest Saudi Arabia, U.S. Geological Survey OpenFile Report 83-641, 56 p.

Sieh, K.E., 1978, Prehistoric large earthquakes produced by slip on the San Andreas fault at Pallett Creek, California: Journal of Geophysical Research, v. 83, p. 3907-3939. 1981, A review of geological evidence for reccurrence times of large earthquakes, in Simpson, D.W., and Richards, P.G., eds., Earthquake prediction, an international review, Maurice Ewing series: American Geophysical Union, v. 4, p. 181-207.

Solomon, S.C., 1973, Shear wave attenuation and melting beneath the mid-Atlantic ridge: Journal of Geophysical Research, v. 78, p. 6044-6059.

Solomon, S.C., and Burr, N.C., 1979, The relationship of source parameters of ridge-crest and transform earthquakes to the thermal structure of oceanic lithosphere: Tectonophysics, v. 55 , p. 107-126.

Steinbrugge, K.V., 1984, Effects of shaking on buildings by class of construction, in Williams, M.W., Proceedings of the Geologic and Hydrologic Hazards Training Program: U.S. Geological Survey Open-File Report 84-760, p. 153-209.

Stepp, J.C., 1973, Analysis of completeness of the earthquake sample in the Puget Sound area, in Harding, S.T., ed., Contributions to seismic zoning: National Oceanic and Atmospheric Administration Technical Report ERL267-ESL30, p. 16-28.

Stewart, L.M., 1983, Strain release along oceanic transforms: New Haven, Conn., Yale University, Ph. D. dissertation, 272 p.

Sykes, L.R., 1967, Mechanism of earthquakes and nature of faulting on the mid-ocean ridges: Journal of Geophysical Research, v. 72, p. 2131-2153.

1970, Focal mechanisms for earthquakes along the world rift system: Seismological Society of America Bulletin, v. 60 , no. 5, p. $1749-1752$.

1978 , Intraplate seismicity reactivation of preexisting zones of weakness, alkaline magmatism, and other tectonism postdating continental fragmentation: Reviews of Geophysics and Space Physics, no. 4, p. 621-668.

Sykes, L.R., and Landisman, M., 1964, The seismicity of East Africa, the Gulf of Aden and the Arabian and Red Seas: Seismological Society of America Bulletin, v. 54, no. 6, p. 1927-1940.

Sykes, L.R., and Nishenko, S.P., 1984, Probabilities of occurrence of large plate rupturing earthquakes for the San Andreas, San Jacinto, and Imperial faults, California, 1983-2003: Journal of Geophysical Research, v. 89, p. 5905-5927.

Sykes, L.R., and Seeber, L., 1982, Great earthquakes and great asperities along the San Andreas fault, southern California [abs.]: EOS, Transactions of the American Geophysical Union, v. 63, p. 1030. 
Trehu, A.M., Nabelek, J.L., and Solomon, S.C., 1981, Source characterization of two Reykjanes Ridge earthquakesSurface waves and moment tensors; P waveforms and nonorthogonal nodal planes: Journal of Geophysical Research, v. 86, no. B3, p. 1701-1724.

Weichert, D.H., 1980, Estimation of earthquake recurrence parameters for unequal observation periods for different magnitudes: Seismological Society of America Bulletin, v. 70, p. 1337-1346.

Whitney, J.W., 1982, Overview of the geomorphology of western Saudi Arabia and recommendations for future research: Saudi Arabian Deputy Ministry for Mineral Resources Open-File Report USGS-OF-02-6, 19 p.

Wilson, J.T., 1965, A new class of faults and their bearing on continental drift: Nature, v. 207, p. 343-347.
Youd, T.L., 1984, Geologic effects-liquefaction and associated ground failure, in Williams, M.W., Proceedings of the Geologic and Hydrologic Hazards Training Program: U.S. Geological Survey Open-File Report 84-760, p. 210-232.

Youd, T.L., and Perkins, D.M., 1978, Mapping of liquefactioninduced ground failure potential: American Society of Civil Engineers, Journal of the Geotechnical Engineering Division, v. 104, no. GT4, p. 433-466.

Zanettin, B., and Justin-Visentin, E., 1975, Tectonical and volcanological evolution of the western Afar margin (Ethiopia), in Pilger, A., and Rösler, A., eds., Afar Depression of Ethiopia: Inter-Union Commission on Geodynamics, Scientific Report No. 14, Verlagsbuchhandlung, Stuttgart, p. 300-309. 
SEISMIC ACTIVITY RATES OF SOURCE ZONES AND SOURCE FAULTS 


\section{APPENDIX}

\section{SEISMIC ACTIVITY RATES OF SOURCE ZONES AND SOURCE FAULTS}

The tabulated seismic activity rates are given at the magnitude 5.0 level as determined from the allocation scheme illustrated in figure 7 and expressed in terms of $\mathrm{n} / \mathrm{yr} / \mathrm{km}^{2}$ for area sources and $\mathrm{n} / \mathrm{yr} / \mathrm{km}$ for fault sources. The $b$-value for all sources is taken as -1.0 .

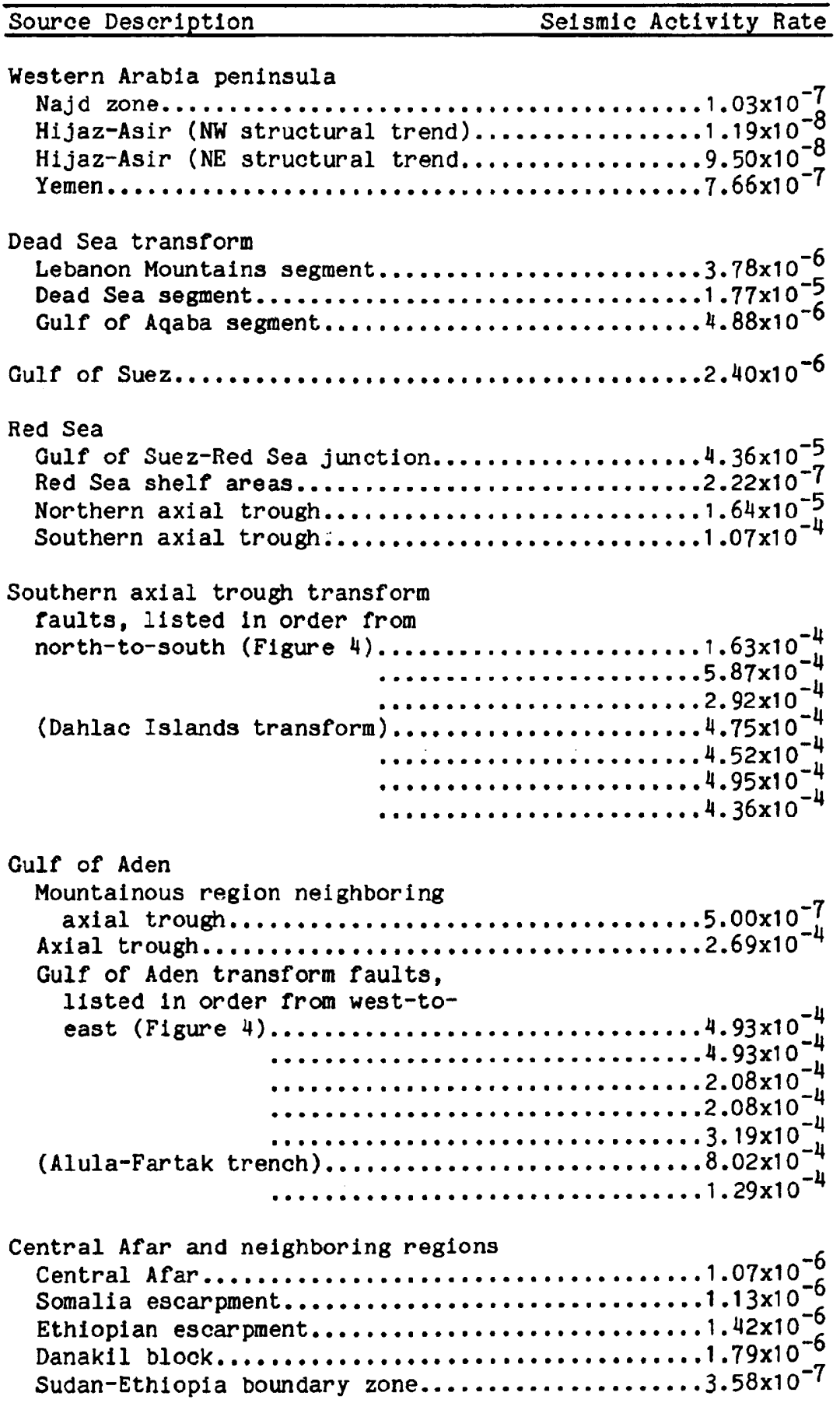






\section{SELECTED SERIES OF U.S. GEOLOGICAL SURVEY PUBLICATIONS}

\section{Perlodicals}

Earthquakes \& Volcanoes (issued bimonthly).

Preliminary Determination of Epicenters (issued monthly).

\section{Technical Books and Reports}

Professional Papers are mainly comprehensive scientific reports of wide and lasting interest and importance to professional scientists and engineers. Included are reports on the results of resource studies and of topographic, hydrologic, and geologic investigations. They also include collections of related papers addressing different aspects of a single scientific topic.

Bulletins contain significant data and interpretations that are of lasting scientific interest but are generally more limited in scope or geographic coverage than Professional Papers. They include the results of resource studies and of geologic and topographic investigations; as well as collections of short papers related to a specific topic.

Water-Supply Papers are comprehensive reports that present significant interpretive results of hydrologic investigations of wide interest to professional geologists, hydrologists, and engineers. The series covers investigations in all phases of hydrology, including hydrogeology, availability of water, quality of water, and use of water.

Circulars present administrative information or important scientific information of wide popular interest in a format designed for distribution at no cost to the public. Information is usually of short-term interest.

Water-Resources Investigations Reports are papers of an interpretive nature made available to the public outside the formal USGS publications series. Copies are reproduced on request unlike formal USGS publications, and they are also available for public inspection at depositories indicated in USGS catalogs.

Open-File Reports include unpublished manuscript reports, maps, and other material that are made available for public consultation at depositories. They are a nonpermanent form of publication that may be cited in other publications as sources of information.

\section{Maps}

Geologic Quadrangle Maps are multicolor geologic maps on topographic bases in 7 1/2-or 15 -minute quadrangle formats (scales mainly $1: 24,000$ or $1: 62,500$ ) showing bedrock, surficial, or engineering geology. Maps generally include brief texts; some maps include structure and columnar sections only.

Geophysical Investigations Maps are on topographic or planimetric bases at various scales; they show results of surveys using geophysical techniques, such as gravity, magnetic, seismic, or radioactivity, which reflect subsurface structures that are of economic or geologic significance. Many maps include correlations with the geology.

Miscellaneous Investigations Series Maps are on planimetric or topographic bases of regular and irregular areas at various scales; they present a wide variety of format and subject matter. The series also includes $71 / 2$-minute quadrangle photogeologic maps on planimetric bases which show geology as interpreted from aerial photographs. Series also includes maps of Mars and the Moon.
Coal Investigations Maps are geologic maps on topographic or planimetric bases at various scales showing bedrock or surficial geology, stratigraphy, and structural relations in certain coal-resource areas.

Oil and Gas Investigations Charts show stratigraphic information for certain oil and gas fields and other areas having petroleum potential.

Miscellaneous Field Studies Maps are multicolor or black-andwhite maps on topographic or planimetric bases on quadrangle or irregular areas at various scales. Pre-1971 maps show bedrock geology in relation to specific mining or mineral-deposit problems; post-1971 maps are primarily black-and-white maps on various subjects such as environmental studies or wildemess mineral investigations.

Hydrologic Investigations Atlases are multicolored or black-andwhite maps on topographic or planimetric bases presenting a wide range of geohydrologic data of both regular and irregular areas; principal scale is $1: 24,000$ and regional studies are at $1: 250,000$ scale or smaller.

\section{Catalogs}

Permanent catalogs, as well as some others, giving comprehensive listings of U.S. Geological Survey publications are available under the conditions indicated below from the U.S. Geological Survey, Books and Open-File Reports Section, Federal Center, Box 25425, Denver, CO 80225. (See latest Price and Availability List.)

"Publications of the Geological Survey, 1879-1961" may be purchased by mail and over the counter in paperback book form and as a set of microfiche.

"Publications of the Geological Survey, 1962-1970" may be purchased by mail and over the counter in paperback book form and as a set of microfiche.

"Publications of the U.S. Geological Survey, 1971- 1981" may be purchased by mail and over the counter in paperback book form (two volumes, publications listing and index) and as a set of microfiche.

Supplements for 1982, 1983, 1984, 1985, 1986, and for subsequent years since the last permanent catalog may be purchased by mail and over the counter in paperback book form.

State catalogs, "List of U.S. Geological Survey Geologic and Water-Supply Reports and Maps For (State)," may be purchased by mail and over the counter in paperback booklet form only

"Price and Availability List of U.S. Geological Survey Publications," issued annually, is available free of charge in paperback booklet form only.

Selected coples of a monthly catalog "New Publications of the U.S. Geological Survey" available free of charge by mail or may be obtained over the counter in paperback booklct form only. Those wishing a free subscription to the monthly catalog "New Publications of the U.S. Geological Survey" should write to the U.S. Geological Survey, 582 National Center, Reston, VA 22092.

Note.--Prices of Government publications listed in older catalogs, announcements, and publications may be incorrect. Therefore, the prices charged may differ from the prices in catalogs, announcements, and publications. 


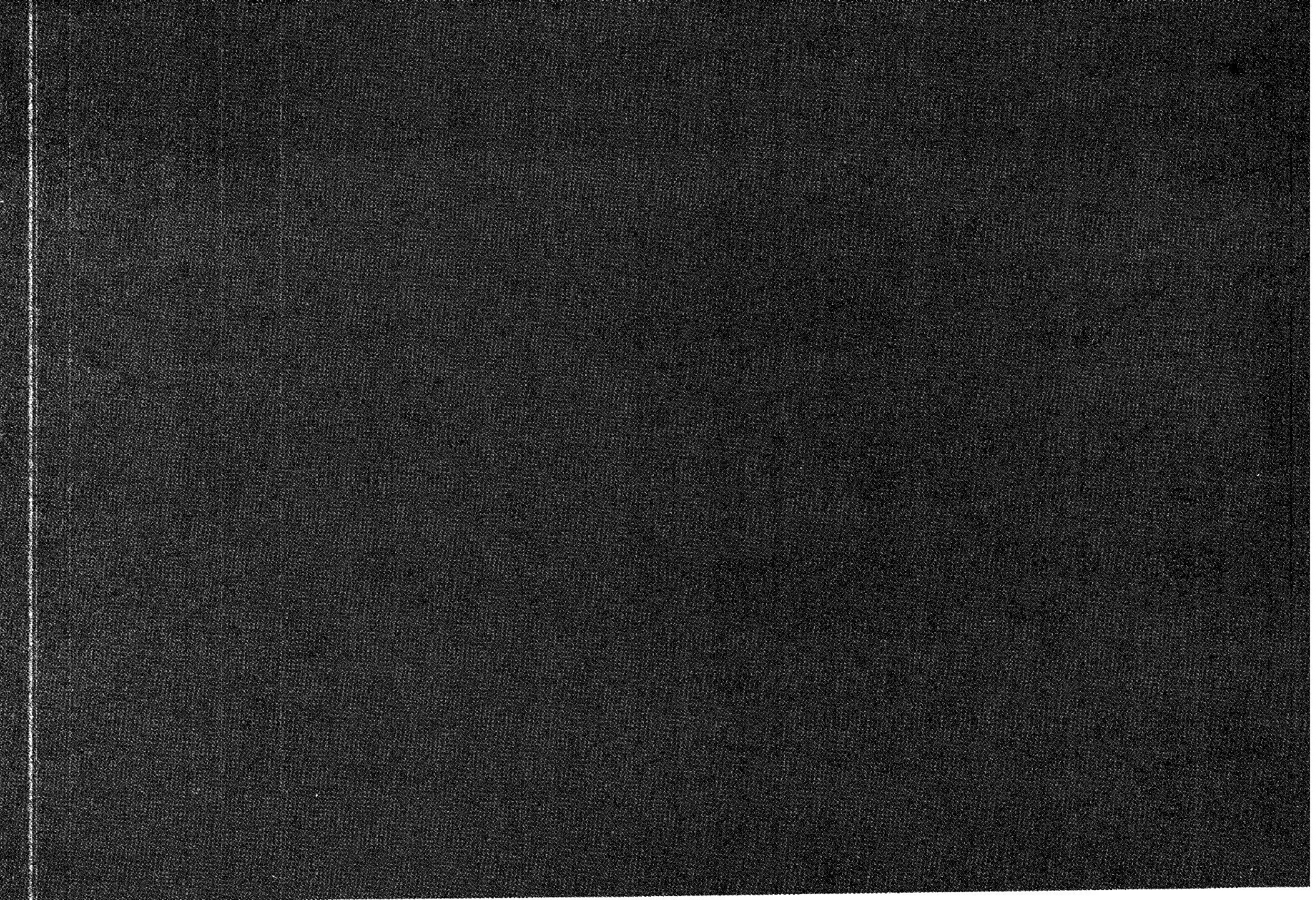

